\title{
Perichondrial arthroplasty of the knee : results and attempts for improvement since 1986
}

Citation for published version (APA):

Bouwmeester, S. J. M. (1999). Perichondrial arthroplasty of the knee : results and attempts for improvement since 1986. [Doctoral Thesis, Maastricht University]. Universiteit Maastricht. https://doi.org/10.26481/dis.19990101sb

Document status and date:

Published: 01/01/1999

DOI:

10.26481/dis.19990101sb

Document Version:

Publisher's PDF, also known as Version of record

\section{Please check the document version of this publication:}

- A submitted manuscript is the version of the article upon submission and before peer-review. There can be important differences between the submitted version and the official published version of record.

People interested in the research are advised to contact the author for the final version of the publication, or visit the DOI to the publisher's website.

- The final author version and the galley proof are versions of the publication after peer review.

- The final published version features the final layout of the paper including the volume, issue and page numbers.

Link to publication

\footnotetext{
General rights rights.

- You may freely distribute the URL identifying the publication in the public portal. please follow below link for the End User Agreement:

www.umlib.nl/taverne-license

Take down policy

If you believe that this document breaches copyright please contact us at:

repository@maastrichtuniversity.nl

providing details and we will investigate your claim.
}

Copyright and moral rights for the publications made accessible in the public portal are retained by the authors and/or other copyright owners and it is a condition of accessing publications that users recognise and abide by the legal requirements associated with these

- Users may download and print one copy of any publication from the public portal for the purpose of private study or research.

- You may not further distribute the material or use it for any profit-making activity or commercial gain

If the publication is distributed under the terms of Article $25 \mathrm{fa}$ of the Dutch Copyright Act, indicated by the "Taverne" license above, 


\section{Perichondrial arthroplasty of the knee}

Results and attempts for improvement since 1986 


\section{Promotor}

Prof. Dr R.G.T. Geesink

\section{Co-promotores}

Dr S.K. Bulstra

Dr R. Kuijer

\section{Beoordelingscommissie}

Prof. Dr M.J.A.P. Daemen (voorzitter)

Prof. Dr C.A. van Blitterswijk (Universiteit Twente)

Dr Ir L.H. Koole

Prof. Dr J.A.N. Verhaar (Erasmus Universiteit Rotterdam)

The financial support by the following organizations is gratefully acknowledged: Academisch Ziekenhuis Maastricht, Sint Maartenskliniek Nijmegen, Nederlandse Orthopaedische Vereniging, Nationaal Reumafonds, Stichting Anna-Fonds, Curasan Benelux BV, Netherlands Bone bank Foundation, Sulzer Medical, Coral Medical BV, Mediprof medical products, Bauerfeind, FMS Benelux BV, NTOC medische techniek, Stryker/Howmedica, Innovative Medical Devices Eindhoven, Johnson \& Johnson medical BV, Storz endoscopie, Basko Healthcare, Stratec Medical, Van Straten orthopaedische techniek, Smith \& Nephew and Rx medical BV. 
Aan mijn ouders

Voor Henk Peter 



\section{CONTENTS}

\section{Chapter 1}

General introduction

\section{Chapter 2}

Methods of biological repair

\section{Chapter 3}

History of perichondrial arthroplasty

\section{Chapter 4}

Aims of this thesis

\section{Chapter 5}

Perichondrial grafting for cartilage lesions of the knee

\section{Chapter 6}

Long-term results of rib perichondrial grafts for the repair of articular cartilage defects in the human knee

\section{Chapter 7}

The polymer Polyactive ${ }^{\mathrm{TM}}$ as a bone-filling substance:

an experimental study in rabbits 


\section{Chapter 8}

Quantitative histological analysis of bony ingrowth within the biomaterial Polyactive ${ }^{\mathrm{TM}}$ implanted in different bone locations: an experimental study in rabbits

\section{Chapter 9}

Histological and biochemical evaluation of perichondrial transplants in human articular cartilage defects

\section{Chapter 10}

Ten year follow-up of human perichondrial grafting versus debridement of cartilage defects in the knee

\section{Chapter 11}

Discussion

Summary

Samenvatting

References

Dankwoord 




\section{CHAPTER 1}

\section{General introduction}

\subsection{Articular cartilage: biology and structure}

Cartilage is composed of chondrocytes embedded within an extracellular matrix. This matrix is a complex arrangement of macromolecules including collagens, proteoglycans, and noncollagenous proteins (1). These constituents keep the proper amount of water inside the matrix in order to provide for the unique mechanical properties. Sixty to eighty percent of the wet weight of cartilage is water. At least $90 \%$ of the collagen present is collagen Type II. The rest consists of collagen Type IX, XI and several minor collagens such as Types V, VI and XIV. Tissues consisting of high amounts of collagen Type II all have high water and proteoglycan contents. This is indicative of the interaction between the collagen and the proteoglycans to maintain a hydrated matrix.

Proteoglycans exist as monomers or as aggregates joined to hyaluronic acid by means of specialized link proteins. Because of the negative charges, proteoglycans are hydrophilic and repel each other. In a collagen network, the proteoglycans are compressed and only partially hydrated. In the process of damaging cartilage, the damaged collagen fibers would allow the proteoglycans to expand and absorb more water, causing the matrix to swell $(2,3)$. Under compression, interstitial fluid flows out of the permeable collagen-proteoglycan matrix. When the load is removed, fluid flows back into the tissue. Because of the low permeability of articular cartilage this provides for a shock-absorbing mechanism. Nutrition of the chondrocytes occurs by diffusion. Fluid flow is important for nutrition of the chondrocytes. Chondrocytes are responsible for matrix synthesis and turnover. In younger animals, chondrocytes proliferate and divide rapidly. They synthesize high amounts of matrix. After skeletal maturity, these processes slow down and the chondrocytes do not divide anymore. 
Morphologically, articular cartilage is divided into four zones: a superficial zone, a transitional zone, a deep zone and the zone of calcified cartilage $(4,5)$. The superficial zone is the thinnest and is composed of thin collagen fibrils aligned parallel to the joint surface. The chondrocytes are inactive, elongated and directly subjacent. The middle zone is thicker than the superficial zone and the cells are more spherical. The collagen fibrils are not oriented in a parallel way. In the deep zone, the cells are spheroidal, arranged in a columnar fashion. Here the collagen fibers, like the cells, are oriented in a parallel fashion and perpendicular to the joint surface $(1,6,7)$. In the zone of calcified cartilage, collagen fibers insert into the calcified cartilage. This provides for a mechanical transition and a good fixation from cartilage to bone.

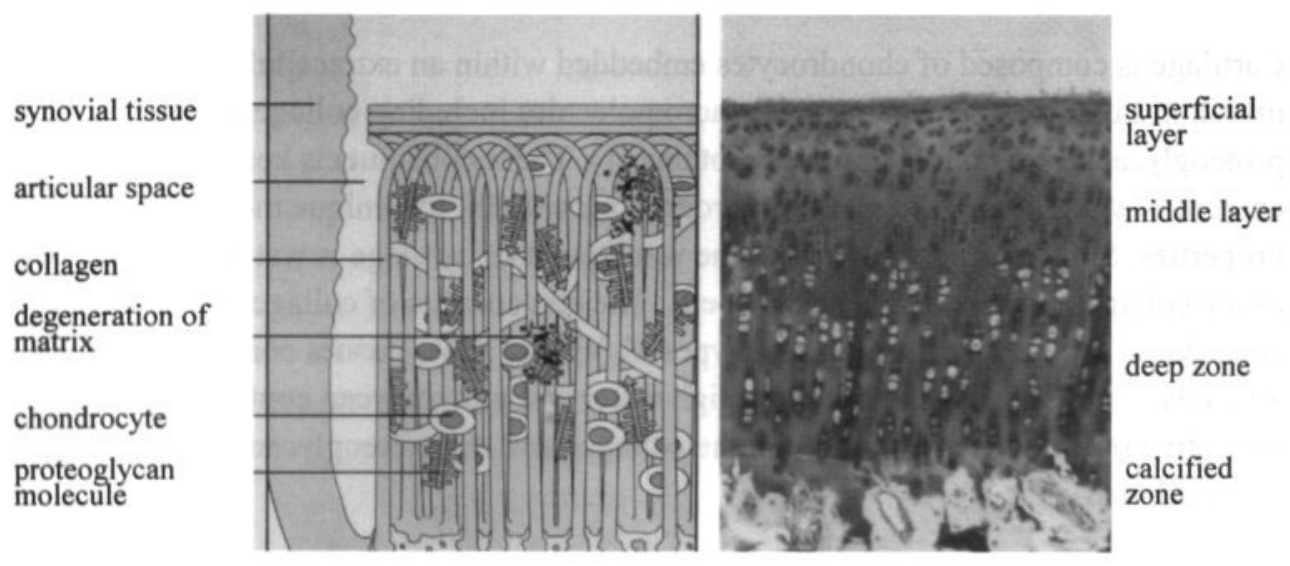

Immediately around the chondrocytes in the pericellular matrix there is very little collagen, but many proteoglycans. Next to the pericellular matrix, in the territorial matrix, the cells are surrounded by thin collagen fibrils that act as a protection zone for the cells. In the interterritorial zone, the largest portion of articular cartilage is organized along lines that enable it to perform its mechanical function.

Cartilage cells originate from mesenchymal cells that round off and multiply. The dense cell mass of chondroblasts synthesize matrix and thereby separate from each other. During the interstitial growth, chondroblasts and chondrocytes multiply and form matrix. At a later stage, the matrix stiffens and growth stops, thereby giving the chondrocytes their definitive position. During degeneration of cartilage, hypertrophy of the cells is seen, cell clusters form, and the matrix calcifies. Cartilage cells die and stop forming the necessary matrix. 
Approximately $60 \%$ of the dry weight of the matrix of hyaline cartilage consists of collagen fibrils. In fibrocartilage relatively more collagens are present. Here, a dense network of collagen Type I fibrils exists. Histologically, hyaline cartilage can easily be distinguished from fibrocartilage by using polarized light. Hyaline cartilage hardly shows any birefringence, whereas the relatively thick collagen type I fibres in fibrocartilage show a clear birefringence.

\subsection{Articular cartilage defects}

Articular cartilage is a remarkable tissue. It can withstand an enormous amount of intensive and repetitive physical stress. At first glance it seems inert and homogenous, but a complex arrangement of different ingredients is responsible for maintaining its unique mechanical properties. Articular cartilage can be damaged by a variety of mechanical, microbiological and chemical agents. Malignment of the limb, previous meniscectomies or instability of the knee can all negatively influence the quality of the cartilage.

Cartilage is vulnerable to traumatic injury or degenerative conditions that may eventually lead to osteoarthritis. This seems to be particularly true in large weightbearing joints such as the knee. Unfortunately, the body is not equipped by mechanisms that repair articular cartilage defects. Even the smallest injury does not restore to normal.

Sometimes the repair tissue consists primarily of fibrocartilage. This is considered to be an inferior tissue because it lacks the mechanical and structural properties of normal cartilage. Fibrocartilage deteriorates over time, thereby allowing the symptoms to recur. Severely symptomatic patients may be in need of a more permanent type of operation such as total knee replacement in order to return to normal daily activities. Especially in younger, more active patients, this type of surgery is not considered to be the best treatment. A serious drawback is the need to revise the knee because of the limited life span. 


\subsection{Wound healing in articular cartilage}

The classic respons of the body to damage consists of a beautifully orchestrated series of reactions (8). In short: at first there is a phase of necrosis of cells and removal of damaged tissue, with the formation of a blood clot with various cells, hormones and cytokines. In the next, inflammatory and granulation phase, transudation of fluid and proteins will facilitate the forming of a dense fibrinous network, containing cells capable of differentiating into repair tissue. In the last remodeling phase, the repair tissue is invaded by vascular buds, creating a vascular granulation tissue and eventually a scar or replicating cells. In most tissues, repair tissue shows fibrotic changes. Only in a few cases, the original tissue is regenerated.

In cartilage these processes are different. Cartilage is an avascular and aneural tissue (8). The inflammatory and reparative aspects that the vascular system provides for are not available to cartilage. In cartilage, the damaged tissue will not be removed by granulocytes and macrophages. The chondrocytes are captured within the collagen network and they are not capable of migrating to the injury site. In a full thickness injury when the subchondral bone is affected, the mechanism of healing by way of the vascular system applies (8-12). The deeper portions of the cellular mass form bone, thereby restoring to some extent the subchondral plate. The reparative tissue in the cartilage defect undergoes metaplasia to a hyaline-like chondroid tissue. The original structure of the cartilage tissue is not restored and different amounts of Type I and II collagen are present. The proteoglycan content decreases significantly and the tangential collagen layers of the superficial zone fail to appear. This fibrocartilage does not have the same mechanical properties as the original cartilage and in the border zone between the original and repair tissue, vertical shear stresses are high. Defects smaller than $3 \mathrm{~mm}$ have a natural ability to heal completely (9). In young, immature animals, the repair tissue is of a better composition. Whenever the repair is insufficient, degeneration of the joint will occur.

Already in 1743 Hunter observed that cartilage, "once destroyed, is not repaired". Until now many research has been focused on repairing articular cartilage defects. A major drawback in most studies is the lack of controlled, prospective randomized studies comparing the outcomes of the various methods of treatment. Many techniques 
have already been described. The short-term results are nearly always promising, but the long-term results have hardly been reported.

Most techniques used up to date have been only partially successful; pain subsides and mobility increases, but often the results are only to a limited extent and last only temporarily.

\subsection{Short survey of repair techniques}

During the last years, several techniques of biological resurfacing have emerged. These can at best eliminate or at least delay the need for an artificial joint prosthesis. Some of these techniques act by stimulating marrow constituents to emerge from the subchondral bone; primitive stem cells are capable of differentiating into bone and cartilage. Examples are: drilling, abrasion burr arthroplasty, spongialization and microfracture. Details of various techniques are described in the next chapter.

Another form of restoring articular cartilage is by transplanting osteochondral allografts, or performing a mosaicplasty in which osteochondral autogenous grafts are transplanted from a non weight-bearing area of the knee to the lesion. Drawbacks here are the transformation of a chondral lesion into a osteochondral one, and in the case of an osteochondral allograft the concommitant risks of transmitting infectious diseases. Autologous chondrocytes can also be harvested, cultured, and then implanted in the defect. A periosteal flap needs to be sutured over the defect in order to captivate the chondrocyte suspension. Again, short-term results are promising, but long-term results will have to be awaited.

Other possible means of obtaining viable cartilage are grafting with perichondrial or periosteal tissue. This technique was first used in smaller joints such as the metacarpal and metaphalangeal joints. In the knee, the fixation of the graft seems to be a bigger problem than in the hand.

Fixation problems either from cells or from perichondrium were addressed by adding a scaffold. Ideally, this had to be a biodegradable, strong and inert material that did not negatively interfere with growth and differentiation of the cells in its environment. 


\section{CHAPTER 2}

\section{Methods of biological repair}

In general, factors that can predispose for degenerative disease are for example malalignment of the limb in varus or valgus, instability of the knee or meniscal pathology. These factors can negatively influence the quality of the cartilage. The first step in preventing further damage to the cartilage is to correct these abnormalities. In order to achieve satisfactory results in repairing cartilage, the two main shortcomings of articular cartilage will have to be corrected: new cells will have to be provided and a useful matrix must be able to form.

Many methods have been used with varying results in animal and human studies. The results have been studied with various methods and grading systems. Comparison of the different techniques is difficult, especially if the follow-up is different. Long-term results may mean as much as 15 to 25 years follow-up.

\subsection{Osteotomies}

Limb malalignment is a significant predisposing factor for focal degenerative lesions of the articular surface. Excessive load of one compartment through varus or valgus malalignment leads to an increase in wear. The loads on the damaged cartilage can be changed by performing an osteotomy. Symptoms decrease and the joint reaction force is directed to the healthy part of the knee. The relief is only temporary and partial, with results lasting approximately 5 years. This technique is reserved for those patients thought to be to young for joint replacement, with a still healthy contralateral compartment in the knee $(13,14)$. Osteotomy with subsequent subchondral drilling yields better results compared to osteotomy alone, but after 2 to 9 years the differences disappear (15). 


\subsection{Shaving of fibrillated or damaged cartilage}

Some cartilage defects can create mechanical problems by formation of unstable flaps or by extensive fibrillation. Symptoms can be locking, catching or crepitus. Synovitis or joint effusion is induced by cartilage debris. Debridement can decrease the mechanical and inflammatory symptoms, but there is no evidence that shaving stimulates repair. In the process of shaving, loose rims or irregular surfaces are smoothed. The subchondral bone is left intact.

The repair tissue resulting from these techniques is more or less disorganized fibrocartilaginous tissue. The amount of collagen Type I will increase and this will have a negative impact on the biomechanical properties of normal articular cartilage (16). The relief is temporary unless an additional operation is performed to correct the underlying abnormality that caused the defect in the first place. Procedures are for instance the correction of the patellar alignment or a tibial osteotomy to correct a varus deformity with a medial compartment involvement $(12,17,18)$.

In 1990 Timoney et al. debrided arthroscopically 109 patients for degenerative osteoarthritis. They found that this treatment offered measurable relief for $63 \%$ of the patients for a significant period of time, although results tended to deteriorate with time (19). In $1991 \mathrm{Kim}$ et al. found that shaving of partial-thickness defects in rabbit patellae did not heal; the underlying cartilage degenerated even further. When subchondral abrasion was performed, hyaline-like tissue formed. This healing was enhanced by continuous passive motion for two weeks post-operatively (18).

\subsection{Penetration of the subchondral plate}

By penetrating the subchondral bone, a pathway is created for the vascular constituents. All elements necessary for a classical wound healing respons are then introduced. These treatments attempt to utilize primitive stem cells, which are capable of differentiating into bone and cartilage. The fibrin clot containing the pluripotential stem cells remodels, resulting in a fibrocartilaginous repair tissue. Different techniques that apply to this mechanism are: drilling multiple holes, microfractures, spongialization and abrasion of a few millimeters of the subchondral plate. Pridie was 
the first to describe drilling techniques in 1959. The area of the defect is drilled in pinpoint fashion to penetrate the vascularization of the subchondral bone, resulting in fibrin clot formation. The repair cartilage which subsequently fills the drill holes has been shown to include both hyaline and fibrocartilage (20).

In 1988 Dzioba performed drilling of the subchondral bone plate. After two years, $69 \%$ of the results were good. The best indications for this technique were acute small to medium partial thickness lesions on the weight-bearing portion of the femoral condyles (21).

In the microfracture technique, the subchondral bone is exposed, gently abraded but left intact, while the adjacent cartilage is debrided to healthy cartilage. The subchondral bone surface is then broached using small picks so that it communicates with the marrow, and clot formation is stimulated. Blevins et al. reported in 1998 the results of microfracture treatment in 140 high-level and recreational athletes with comparable lesions and follow-up. Significant improvements in function and symptoms from time of microfracture to the final follow-up of 4 years were noted. These results were similar for the competitive and recreational athletes (22).

Since 1975, spongialization was performed by Ficat et al. This procedure resects, en bloc, all of the diseased cartilage with its corresponding subchondral bone, leaving a completely exposed cancellous bony bed. This procedure was thought to be superior to drilling alone since the subchondral plate itself is abnormal and often of poor quality, dense and ischaemic. In addition a depression was created in which the new tissue could regenerate without the adverse effect of weight-bearing load imposed by the opposite cartilage surface. Another reason for removing the subchondral plate was the elimination of the source of the pain, since the subchondral bone is well innervated and sensitive to pressure transmitted by softened cartilage (23). Using spongialization, the authors reported good or excellent results in $79 \%$ of the patients.

Abrasion arthroplasty involves debriding the articular defect to a normal tissue edge so that fresh collagen capable of binding to a fibrin clot is exposed. The surface of the subchondral bone is then exposed and superficially penetrated. A blood clot is formed on the surface of the subchondral bone. Johnson and Dandy reported arthroscopic abrasion arthroplasty with somewhat unpredictable results. In the more favourable 
cases, the results were only temporary. Most studies reported a hyaline-like cartilage, but deterioration over time with changes to fibrocartilage occurred (24).

Another study comparing abrasion burr arthroplasty with subchondral drilling was performed in rabbits by Menche et al. in 1996 (165). In the case of drilling, small burr holes are made in the subchondral bone. Degenerative changes in the cartilage surface were observed with both treatments. Rabbits undergoing subchondral drilling had increased fibrocartilaginous healing with time, with a light increase in degenerative changes. With burr arthroplasty, there was a significant decrease in cartilaginous coverage of the exposed surface as well as a progressive increase in degenerative changes.

\subsection{Osteochondral grafts}

\section{Allografts}

The long-term viability of any chondral graft depends on the structural integrity of the matrix and the contact with the underlying bone. In osteochondral grafts, this structural integrity is provided for. An important advantage of this technique is the fact that the graft can be taken from approximately the same site as where the recipient's defect is. This provides for a graft with exactly the same thickness, contour and compliance. A major disadvantage is the risk of transmitting an infection like hepatitus or the human immunodeficiency virus. To eliminate the risk to a major extent, freeze drying of the osteochondral graft can be performed. This reduces the immunogenicity, but also decreases the viability of the transplanted chondrocytes $(25,26)$.

Czitrom et al. demonstrated in 1990 the ability of articular cartilage in fresh osteochondral allografts to survive after transplantation in humans. Biopsies were labeled radio-actively and studied by autoradiography (27).

In 1992, Mahomed et al. reported on 92 fresh osteochondral allografts in 91 patients. Unipolar grafts, which involve only one surface of the compartment, and bipolar grafts which involve both surfaces, were used. The unipolar grafts had a lower failure 
rate at all periods compared to bipolar grafts, with $75 \%$ survival at 5 years, $69 \%$ at 10 years and $67 \%$ at 14 years $(28)$.

\section{Autografts}

Some advantages of autografts over allografts are that the transmission of disease is not present and the viability of the chondrocytes is high. Disadvantages are the limited supply of autogenous tissue, the adverse effect on joint function, and the difficulty of matching the topology of the donor graft to the defect site. The donor grafts are usually taken from areas of the joint less important for joint function, for example the lateral edge of the lateral femoral condyle, or from around the intercondylar notch.

Multiple osteochondral arthroscopic transplantation (mosaicplasty) was first reported by Matsusue et al. Second-look arthroscopy demonstrated an excellent fill with a good clinical outcome after three years (29). Hangody et al. reported a follow-up of more than three years showing good or excellent results in $91 \%$ of the patients. The donor sites were filled with cancellous bone and fibrocartilage as seen during second-look arthroscopies. No donor site morbidity was experienced (30,31). Drawbacks of this technique are the difficulty of matching the donorgraft to the recipient's site, and the differences in the structure, thickness and compliance of the different cartilage sites.

\subsection{Chondrocyte transfer}

Different studies have reported the technique of transplantation of chondrocytes, either from animals or humans, from articular cartilage or epiphyses (32). In order to obtain sufficient numbers of chondrocytes, cells were cultured and transplanted into the defect. In the proliferative stage taking place during the first 4 weeks, the number of chondrocytes increase and small amounts of extracellular glycosaminoglycans are produced. Between 4 and 8 weeks, the maturation stage takes over and cartilage is formed. The cells differentiate and the rate of proliferation decreases. The rate of matrix synthesis correspondingly increases. In the final transformation stage which takes place between 2 and 6 months after transplantation, vascular elements proliferate and penetrate the subchondral portion of the implant (33). 
In 1994, Brittberg et al. performed a study with this technique in patients. Cartilage was harvested (either open or arthroscopically) from a minor load-bearing area on the upper medial femoral condyle. The cartilage was sent to the laboratory where it was minced, enzymatically digested to separate cells from matrix. Cells were cultured in a medium and expanded. Two weeks later the cells were reimplanted under a periosteal cover fixed by sutures. The periosteal patch served as a watertight seal and acted as a protective semipermeable membrane. The subchondral plate was cleaned but not penetrated. Post-operatively, weight-bearing gradually started after 2 to 3 months. After three months, arthroscopy showed that the transplants were level with the surrounding tissue and spongy when probed, with visible borders. Two months after surgery, $87 \%$ had good results (34). Collagen typing of the newly formed cartilage was not performed.

As in the majority of the clinical studies, a drawback of this study is that it is not a controlled, randomized clinical study. The natural history of articular cartilage defects can be similar to debridement, drilling or other transplantation methods. Another important issue is the absence of collagen typing, which provides important information concerning the type and quality of the repair tissue. As to this moment no negative results have been published, though one has to keep in mind that this technique still is very young.

In 1997, Breinan et al. published the results of the effects of cultured autologous chondrocytes on repair of chondral defects in a canine model. In one group, cultured chondrocytes were implanted under a periosteal flap. In the second group, the defect was covered with a periosteal flap but no autologous chondrocytes were implanted. In the third (control) group, the defects were left empty. The defects were analyzed after twelve and eighteen months. No significant difference among the three groups with regard to any of the parameters used to assess the quality of the repair could be detected. In the two groups in which a periosteal flap was sutured to the articular cartilage surrounding the defect, the articular cartilage showed degenerative changes that appeared to be related to that suturing (170). 


\subsection{Mesenchymal stem cells}

Chondrocytes develop according to their topographic location in the host. This can be explained by the apparent control that the microenvironment has on cellular differentiation and phenotypic expression (33). The use of undifferentiated stem cells would allow greater adaptation to the microenvironment than mature cells $(35,36)$. The resulting tissue resembles more the original, native tissue. A disadvantage of this technique is that the number of pluripotential stem cells present in a host declines rapidly with older age (35). In theory this technique is a promising one. It is in the very first stages of development and more has to be learned before this can be applied to humans.

\subsection{Periosteal grafts}

A number of experimental and clinical studies have shown that free periosteal and osteoperiosteal grafts can regenerate articular cartilage (37). The highest chondrogenic potential was seen from periosteum from the iliac crest. Within the tibia, the upper and middle zones of the proximal region were similar and were slightly better than the lower proximal tibia or the distal tibia (38).

O'Driscoll and Salter showed the chondrogenic potential of autogenous periosteal grafts under the influence of continuous passive motion and demonstrated durability of the regenerated surface after 1 year (39). The authors observed that the results were significantly worse when the orientation of the periosteal graft was reversed (when it had been sutured into the defect with the cambium layer of the graft facing the subchondral bone) or when no periosteal graft was used. They also proved that 4 weeks of continuous passive motion resulted in more Type II collagen inside the graft as compared to 2 weeks of continuous passive motion, intermittent active motion or total immobilization $(40,41)$.

Moran et al. noted abnormalities in the arrangement and distribution of Type II collagen. Also evidence of chondrocyte degeneration in the neocartilage was observed (42). In some studies fibrin sealant was used to secure the periosteal graft to the underlying bone. In most studies, hyaline-like tissue was found. 


\subsection{Perichondrium grafts}

Another source of stem cells for cartilage is perichondrium. A major advantage is that the cells naturally reside in the perichondrium and thus this natural scaffold can be fitted in the defect. Another advantage is that there is no morbidity in the knee associated with the use of articular cartilage, like in the use of osteochondral grafts or chondrocyte transfer. Some difficulties of attaching the perichondrium to the underlying bone occurred (43). The contact between the graft and the subchondral bone should be intimate. Some work has been done to study the fixation of the graft by using fibrin glue (44-48). Perforation of the perichondrium also minimized the chance of loosening of the graft. Chapter three deals with the history of the use of perichondrium in detail.

\subsection{Artificial scaffolds}

When articular cartilage is damaged, changes take place in the subchondral bone. Sclerotic changes of the subchondral bone as seen in osteoarthritis impair its function as a proper receiver of the load transmitted by the cartilage $(1,49)$. Cartilage can only partially absorb the load itself. The function of articular cartilage is to transmit load to the subchondral bone. Whenever the subchondral bone is not capable of receiving the load properly because it is too sclerotic, attempts to repair or regenerate articular cartilage are likely to fail.

Synthetic and biological scaffolds have been introduced, for example, to provide a basis for a perichondrial graft or for an initial framework for cultured chondrocytes. These chondrocytes are then stabilized in the defect and take their spatial position within the repair tissue before they synthesize collagens and proteoglycans. Scaffolds can also be used as carriers for various growth factors and other bio-active molecules. They should preferably also be able to resist the osmotic pressure by proteoglycans and the very high loads that articular cartilage is subjected to. Many substances have been investigated, including fibrinogen-based materials, polytetrafluoroethylene (ptfe), collagen gels, carbon fiber pads, and polylactic and polyglycolic acid meshes (50-55). Whenever a scaffold is implanted, it will take a few days to weeks for new cells to fill a cartilage defect and it will take several months for this tissue to mature 
and differentiate into hyaline articular cartilage. Scaffolds should preferably be biodegradable, also within articular cartilage, and they should not influence the differentiation of stem cells into chondrocytes or osteoblasts. A proper scaffold should at best have disappeared completely before maturation is complete. Otherwise remnants of the degrading scaffold may weaken the tissue and result in new damage to the joint. 


\section{CHAPTER 3}

\section{History of perichondrial arthroplasty}

The potential of perichondrium to form cartilage was first documented by Tizzoni in 1878 and confirmed by Marchand, Matsuoka, Mori and Malatesta 25 years later. In the 1930 's, the formation of fibrocartilage was mentioned, but clinical application went unrecognized for a long time $(56,57)$.

This changed in 1972 when Skoog and Ohlsén reported the use of rabbit perichondrium which was stripped away from the ear cartilage and raised as a flap. There was progressive regeneration of cartilage originating from the perichondrium (58). In 1975, the same group investigated the exact origin of the newly formed cartilage in rabbits. They found that the deep surface of the perichondrial flap formed the cartilage. The effect of a hematoma as a matrix for this growth was evident (59). Ohlsén found in 1977 that, when implanted into different regions of the body, perichondrium produced cartilage in the presence of blood. He transplanted free perichondrial flaps to the subcutaneous tissues in the neck, to the muscles of the back and to the parenchym of the liver. Free perichondrial grafts were used clinically in deformities of the human ear, and experimentally in the trachea of dogs and in articular cartilage defects in rabbits (60).

In the same year, Wasteson and Ohlsén labeled the newly formed tissue in rabbits with $\left[{ }^{35} \mathrm{~S}\right]$ and showed that this tissue contained chondroitin suphate. Thus, the newly formed tissue showed a biosynthetic capacity displayed by all cartilaginous tissues (61).

In 1978 Tajima et al. used rib perichondrium to treat temporomandibular ankylosis in 6 patients. The preliminary results were excellent and after 1,5 years no radiographical evidence of marginal calcification was seen (62). 
Engkvist and Skoog reported in 1979 on the cartilaginous potential of perichondrium in rabbit ear and rib. Rabbit perichondrium from the rib appeared to have a greater cartilaginous potential than that from the ear both in vivo and in vitro. In an experimental study in rabbits they produced an articular defect in the glenoid surface of the humero-scapular joint. Auricular perichondrium was grafted with the active chondrogenic layer of the perichondrial graft facing the joint cavity $(63,64)$. Regeneration of cartilage occurred in 12 out of 14 rabbits. The same procedure was performed in adult dogs in which the articular cartilage of the patella was excised completely. In all 13 dogs regeneration of cartilage took place. Slight degenerative changes were seen after 12 months and the grafts could not resist considerable pressure forces.

Again it was proven, using the technique of tritiated thymidine, that mitotic activity was found in the superficial zone of the regenerated cartilage indicating that the proliferation of cells was initiated from the perichondrium.

Maruyama demonstrated in 1979 that the chondrogenic activity of perichondrial grafts was influenced by age and the blood supply to the perichondrium in rabbits. Pedicled perichondrial grafts performed better than free grafts. In older rabbits less activity in creating new cartilage was seen and the duration of time to mature was more prolonged than in young rabbits (65).

In the same year Upton et al. investigated the newly formed tissue. The neocartilage was composed of sufficient amounts of chondroitin sulfate: histologic appearances ranged from hyaline cartilage to fibrocartilage to fibrous tissue. The ability of cultures of perichondrocytes to synthesize chondroitin sulfate under serum-free conditions was evidence that these cells were unlike fibroblasts and more like chondrocytes in their in vitro behavior (66).

Engkvist and Johansson used this technique in 1980 to reconstruct smaller joints such as the carpometacarpal and metacarpophalangeal joints in the plastic surgery setting (67). The poor results in these joints were thought to be caused by high strains on the joints, the presence of rheumatoid arthritis, ankylotic joints before the operation and extensive soft tissue loss. They concluded that the cancellous bone had to be exposed, thereby offering the graft a vascularized bed. Immobilization post-operatively had to be maintained for two weeks in order to allow vessels to grow in. Sully and Jackson 
grafted rheumatoid metacarpophalangeal joints in patients and used silastic spacers in the joints. The major technical problem was the production of planar, rather than concavoconvex joint surfaces. The flat silastic spacer had a considerable influence in moulding the final shape. After this, they changed the spacer into a more shaped one. They were unable to produce a significant amount of actual cartilage from the perichondrial grafts. Indications for the procedure in rheumatoid arthritis were limited since loss of articular cartilage was not a primary feature of the disease, but rather arose secundary to synovial proliferation and bony erosion, leading eventually to articular collaps. Of interest in the last two studies was that patients who underwent replacement arthroplasties in the other hand preferred the natural feel of the perichondrioplasties (68).

Kon stated in 1981 that the transplants had to be fixed with the chondral side facing the joint. The other side contained the vascular network and revascularization of these capillaries from the subchondral bone contributed to the survival of the graft and its acceptance. The neocartilage of younger rabbits was slightly thicker than in adult rabbits, but in the latter the cells were more mature (69).

Ohlsén and Widenfalk grafted 39 rabbit knees in 1983 with perichondrium. The graft was fixed to the subchondral bone with fibrin glue and they found that no vascular proliferations penetrated the glue. They concluded that the graft was nourished from the synovial fluid only (70).

In 1984, Coutts et al. reported that best growth from rib perichondrium of a rabbit was achieved when the fixation of the graft was secure and with complete conformity to the recipient's bed. Immobilization enhanced the fixation of the graft, but also permitted fibrous growth onto the graft (71). Seradge et al. in the same year stated that perichondrial resurfacing arthroplasty should be considered contraindicated in the treatment of patients with a history of pyarthrosis, systemic diseases with joint involvement, concomitant tendon reconstruction, and in patients over 40 years old (72).

The post-operative time for fixation of the perichondrial graft was reduced from three to one week by using fibrin glue. Widenfalk et al. found in 1986 the same results regarding graft healing and cartilage regeneration (73). 
Woo et al. studied in 1987 the shear modulus of neocartilage in rabbits. It appeared that in the first 6 weeks, continuous passive motion applied intermittently for 2 weeks enhanced the formation of quality neocartilage. The magnitude of the complex shear moduli was higher than in the animals that were not subjected to continuous passive motion. The differences disappeared when longer time periods were considered (74).

Amiel et al. in 1988 found early formation of relatively large amounts of glycosaminoglycans in the neocartilage derived from perichondrial grafts. A steady increase in the proportion of type II collagen was observed 6, 12, 18, 26 and 52 weeks after grafting in rabbit knees (75).

Bruns et al. reported in 1992 that the newly formed cartilage from rib perichondrial transplants in sheep knees showed synthesis of proteoglycans and glycoproteins. Enzyme histochemistry for alkaline and acid phosphatase activity showed positive reactivity only at the base of the transplant (44). In 1993, the fixation of the graft was studied by comparing fibrin glue and collagen sponges. Histology revealed a subchondral transition zone similar to enchondral ossification following fixation with fibrin glue, whereas in cases with collagen sponge fixation, a broad zone of fibrous tissue was visible. Besides this, foreign-body giant cell formation was detectable after the use of collagen sponges. From this study it was concluded that fibrin glue was necessary and safe for perichondrial graft fixation and the following immediate postoperative mobilization.

Homminga et al. reported in 1989 that in 26 out of 30 rabbit knees, fixation with fibrin glue proved to be adequate. The perichondrium developed macroscopically and histologically into normal hyaline cartilage (46). In a different study, the same group found no immunologic reaction after transplanting a rabbit costal perichondrial graft to an articular cartilage defect in a sheep knee. After 12 weeks cartilage was formed with increased calcification of the basal layer and a mean of $74 \%$ collagen type II was found (48).

In 1990, Bulstra et al. reported on the presence of glycosaminoglycans normal for hyaline cartilage in human perichondrial explants cultured for 7 or 10 days. The perichondrial cells differentiated towards chondrocytes and new matrix substances normally present in hyaline cartilage were produced (47). 
In chapter 5,6,9 and 10, the clinical results of perichondrial arthroplasty in humans are shown. After approximately one year, most patients were satisfied with the result. 


\section{CHAPTER 4}

\section{Aims of this thesis}

In this thesis the results of the rib perichondrial arthroplasties as performed in over 150 patients in the University Hospital Maastricht were critically evaluated. The primary results of the perichondrial arthroplasty were followed and patients were regularly examined. An important question was why some patients did so well while others did not. The question arose whether this was due to an improper patient selection or to a failure of the technique.

Already in an early state fixation problems of the graft were noticable. Solutions for this problem were sought and again the quality of the newly formed cartilage from the perichondrial transplant was assessed.

The quality of the subchondral bone deserved special attention. It is well-known that this part of the bone carries the loads transmitted by the cartilage. It is also important for the strong fixation of the cartilage. Defects in the subchondral bone predispose for degenerative disease. Attempts were made to improve the basis for the perichondrium graft by using a biodegradable, biocompatible polymer called Polyactive ${ }^{\mathrm{TM}}$. Calcification of the graft was also a problem when this technique was first used. A study with Polyactive ${ }^{\mathrm{TM}}$ was done because this polymer can act as a barrier for the calcification originating in the subchondral bone.

An important aim of this thesis was the formulation of the best criteria for performing a perichondrial arthroplasty. This was done by critically evaluating all patients operated on up to now.

Finally, the question was investigated whether this technique was superior to the already established techniques of addressing articular cartilage defects. A comparison was made between perichondrial arthroplasty and debridement and drilling of the subchondral bone in patients complying to the same inclusion criteria. 


\section{CHAPTER 5}

\section{Perichondrial grafting for cartilage lesions of the knee}

G.N. Homminga, S.K. Bulstra, S.J.M. Bouwmeester, A.J. van der Linden

The Journal of Bone and Joint Surgery, British Volume, 72-B:1003-1007, 1990 


\section{SUMMARY}

Twenty-five patients with 30 chondral lesions of the knee were treated with an autogenous strip of costal perichondrium. The graft was fixed to the subchondral bone with Tissucol (Immuno,Vienna), a human fibrin glue. The leg was then immobilised for two weeks followed by two weeks of continuous passive motion. Weight-bearing was permitted after three months.

The mean knee score changed from 73 before operation to 90 one year after; in 14 patients evaluated after two years there was no decrease. In 28 cases the defect was completely filled with tissue resembling articular cartilage. We conclude that in most cases perichondrial arthroplasty of cartilage defects of the knee gives excellent results. 


\section{INTRODUCTION}

With the increasing use of the arthroscope, chondral lesions of the knee are being diagnosed more frequently $(21,24,77-79)$. Until recently, treatment was limited to abrasion and drilling of the subchondral bone, resulting in repair tissue which is fibrocartilaginous $(12,20,80)$. Perichondrium, taken form the cartilaginous part of a rib, can develop into normal hyaline cartilage when placed in a joint $(63,81)$. Woo et al. (1987) demonstrated that this newly-formed tissue had the same visco-elastic properties as hyaline cartilage, and Amiel et al. (1988), one year after perichondrial grafting, found neocartilage with histological and biochemical qualities similar to those of normal articular cartilage $(74,75)$.

In clinical practice this method of arthroplasty has been successfully used in many other joints $(62,67,68,81-84)$. Nearly all these studies dealt with small joints in which the whole articular surface was reconstructed. Perichondrial grafting of large full thickness lesions in larger joints, like the knee, seemed to be a problem because a biological method of graft fixation was not available. Widenfalk et al. (1986) however, used fibrin glue for fixation; this is non-toxic, non-allergic and biodegradable. It has a low initial adhesive strength, but this increases rapidly (73). We have used this method successfully in the rabbit knee (46) and we now report our results in patients.

\section{PATIENTS AND METHODS}

From November 1986, patients with a symptomatic cartilage lesion of the knee were treated with an autogenous costal perichondrial graft. They were selected after diagnostic arthroscopy and those with radiological and arthroscopic evidence of arthritis were excluded. Most of the patients had been treated conservatively first, and the mean time between the onset of symptoms and operation was 37 months (range 2 to 144). Thirty cartilage lesions were treated in 25 patients: 12 right and 13 left knees in 20 men and five women. The mean age at the time of operation was 31 years (range 18 to 45$)$. Ten lesions were of traumatic origin; three were from osteochondritis dissecans which had been treated unsuccessfully by drilling, and in five, chondomalacia was the supposed cause of a cartilage lesion of the patella. In seven 
cases degeneration of cartilage had taken place; in two of these there was chondrocalcinosis, but in five the cause was not identified. Eleven patients had had operative treatment previously, mainly consisting of removal of degenerated cartilage and drilling of the underlying bone. Lateral releases had been performed in three cases of chondromalacia patellae.

We studied the type of lesion, its location, any fibrillation or flap tears, exposure of the bone and extent of the lesion. If necessary a hook was used to assess whether the chondral lesion extended to the underlying bone. All 30 lesions were classified according to Bauer and Jackson (1988) and are listed in Table I (79). Most were situated in the anterior and lateral intercondylar regions of the medial femoral condyle, or in the medial and central areas of the patella (Table II).

\section{Table I.}

Classification of the 30 cartilage lesions, according to Bauer and Jackson (1988)

\begin{tabular}{llc}
\hline \multicolumn{2}{l}{ Type of lesion } & Number \\
\hline I & Line crack & 0 \\
II & Stellate fracture & 0 \\
III & Flap & 4 \\
IV & Crater & 6 \\
V & Fibrillation & 12 \\
VI & Degrading & 8 \\
\hline
\end{tabular}

\section{Table II.}

Locations of the 30 cartilage lesions

\begin{tabular}{ll}
\hline Location & Number \\
\hline Medial femoral condyle & 15 \\
Patella & 11 \\
Lateral femoral condyle & 3 \\
Intercondylar groove & 1 \\
\hline
\end{tabular}

The size of the perichondrial grafts varied from 1 to $5 \mathrm{~cm}^{2}$ (mean $2.13 \mathrm{~cm}^{2}$ ). In two cases a ruptured anterior cruciate ligament was diagnosed; it was associated with signs of instability. Before operation anteroposterior, lateral and axial radiographs of the affected knee were taken; in seven, osteophytes were present. 
Technique. General anaesthesia is used and the affected leg is exsanguinated. Through a medial parapatellar incision the knee is opened and the patella dislocated laterally. The chondral lesion is identified and cleaned as far as the subchondral bone. The lesion is extended into the sound surrounding cartilage, creating a sharp border with a vertical edge.

An oblique incision is made over the lower part of the left side of the chest. The fascia of the rectus muscle is split transversely and the muscle in the line of its fibres. A piece of perichondrium is dissected from the cartilaginous part of one of the lower ribs and removed together with its chondrogenic layer. The graft is cut to match the size of the defect; it is sometimes necessary to use two pieces of perichondrium. Tissucol, a human fibrin glue, is prepared by mixing fibrinogen ( 70 to $110 \mathrm{mg} / \mathrm{ml}$ ) with aprotinin $(3000 \mathrm{KIE} / \mathrm{ml})$ and thrombin $(4 \mathrm{IE})$ with calcium chloride $(40 \mathrm{mmol} / \mathrm{l})$. After heating these mixtures to $37^{\circ} \mathrm{C}$ they are brought together and applied to the defect. The perichondrial graft is placed on the subchondral bone with the chondral side facing the joint; it is firmly pressed to the underlying bone with a wet gauze for one minute.

After closing the wounds, a Robert Jones bandage is applied and also a dorsal plaster slab. Two weeks later continuous passive motion is started; for grafted lesions of the patella or the intercondylar groove, flexion is restricted tot $30^{\circ}$. From the fourth week onward the patient is allowed to walk with crutches without putting weight on the affected leg; active movements are encouraged. Weight-bearing is permitted from three months after the operation.

In two patients with instability due to a torn anterior cruciate ligament, perichondrial arthroplasty was combined with reconstruction of the ligament using the central portion of the patellar tendon.

\section{RESULTS}

The results were assessed by means of arthroscopy in all 25 patients, biopsy of the graft in three, change of knee score after one year in all 25, and again after two years in 14 , and by radiological examination in all.

\section{Arthroscopy}

This was performed in all 25 knees at three to 12 months after transplantation (average 10). Of the 30 grafted cartilage defects, 27 had completely filled with tissue 
resembling cartilage. In two cases an unchanged defect of the weight-bearing part of one femoral condyle was seen and one patella graft was covered with white tissue, though the surface was fibrillated. A hook was always used to assess the consistency of the graft. After three months the newly-formed tissue looked white and was elevated above the surrounding cartilage. The surface was still soft, but the deeper layer felt solid. After one year the grafted area strongly resembled the surrounding cartilage.

\section{Biopsy}

The three biopsies were taken one year after grafting and kept in neutral formalin, decalcified, embedded in paraffin, sectioned at $10 \mu \mathrm{m}$ and stained with haematoxylineosin and Alcian blue (the second specimen was not decalcified so that calcium staining by Kossa's method was possible). Macroscopically the biopsies formed a solid core of bone firmly attached to a thick layer of cartilage. Microscopy revealed disruption of cartilage and bone in two cases; in the third there was uninterrupted contact between the two tissues.

The predominant tissue in the biopsies was cartilage. No mitosis or clustering of chondrocytes were seen. With Alcian blue a diffuse blue staining of the intercellular ground substance (matrix) was seen, indicating the presence of acid mucopolysaccharides, exclusively produced by chondrocytes. The cells looked like normal chondrocytes with pericellular lacunae. With the Kossa staining, the subchondral bone stained black as well as part of the basal layer of the cartilage. No signs of ossification were present in this layer.

\section{Knee score}

One year after operation all the patients were questioned and examined. The mean preoperative knee score was 73 (s.d. 9), which increased to 90 (s.d. 10) after one year (paired $t$-test, $p<0.001$ ); thus the mean change in knee score was 17 (s.d. 9), (range -14.5 to 35 ). One year after operation 18 patients were completely free of symptoms: they had resumed their previous work and sports activities. Using the classification of Ranawat et al. (1976), most patients changed from good (70 to 84 points) to excellent ( 85 to 100 points), some from fair (60 to 69 points) to excellent and a minority from good to perfect (100 points) (76). One patient changed from poor ( $<60$ points) to good, one from poor to excellent and one from fair to good. Two patients remained good and two remained excellent (these last two had complained of pain at work but were able to resume work four to five months after operation). 


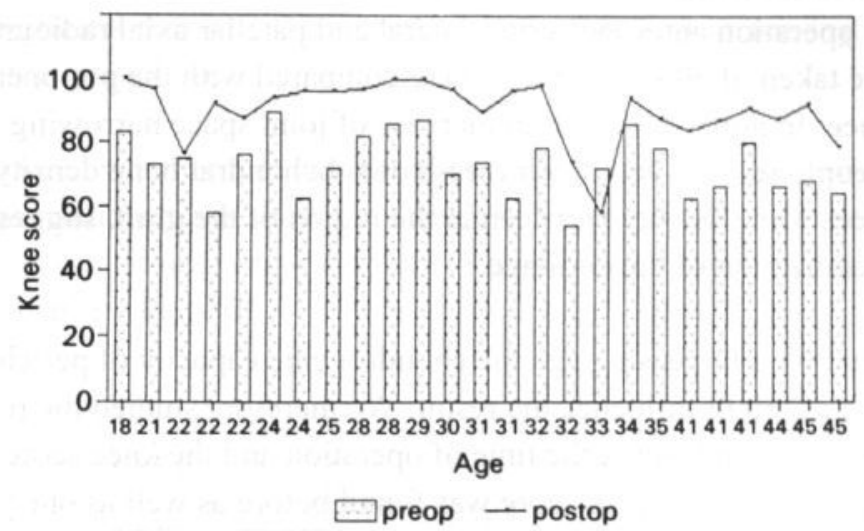

Figure 1. Pre-operative and post-operative knee score related to the age of the patient.

The first 14 patients operated upon were evaluated again after 17 to 32 months (mean 23.5). This was done to assess whether the condition of the graft and subsequently of the knee might deteriorate with time. The mean knee score after this period of time was 87 (range 67 to 100), whereas it had been 85 (range 75 to 100) after one year; thus there was no statistical difference (paired $t$-test: NS). Three patients with a relatively low knee score after one year had a decreased score after two years, but those with no complaints after one year remained excellent in the following year.

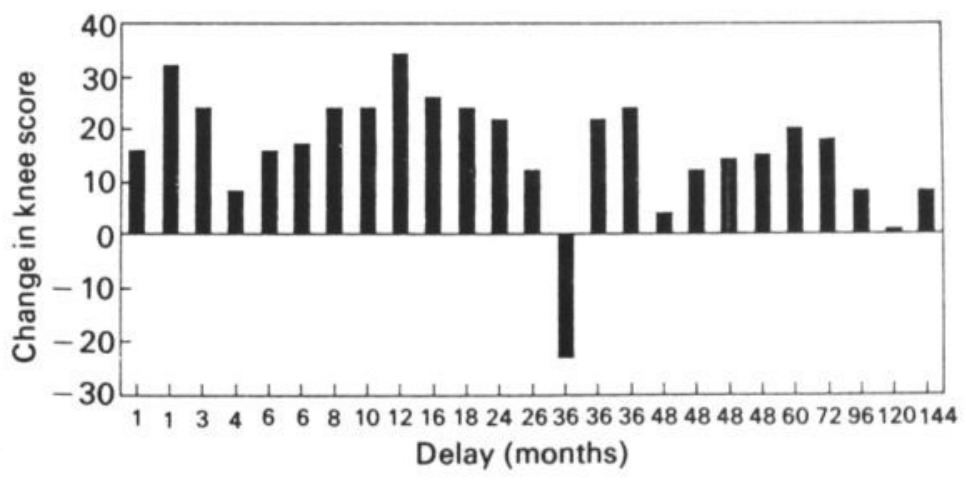

Figure 2. Relation between the change in knee score and the pre-operative delay. 


\section{Radiological examination}

One year after operation anteroposterior, lateral and patellar axial radiographs in $30^{\circ}$ of flexion were taken of all knees; these were compared with the pre-operative films of the same knee. In none was there an increase of joint space narrowing, or of the number of osteophytes, nor was any increase of subchondral bone density or cysts seen. In 20 knees some density was seen in the region of the graft, suggesting increased mineralization of the cartilage.

It is possible that with increasing age the chondrogenic capacity of perichondrium decreases, and this might influence the result. We therefore studied the relation between the age of the patient at the time of operation and the knee score. With increasing age a decrease in knee score was found before as well as one year after operation; however, the result of the operation, as measured by the difference in knee score before and after, was not influenced by the age of the patient (Fig. 1). The Spearman rank correlation coefficient for this relationship was 0.0172 (NS). For the relationship between age and post-operative knee score the Spearman rank correlation coefficient was -0.2656 . It may be concluded that the results were not related to age.

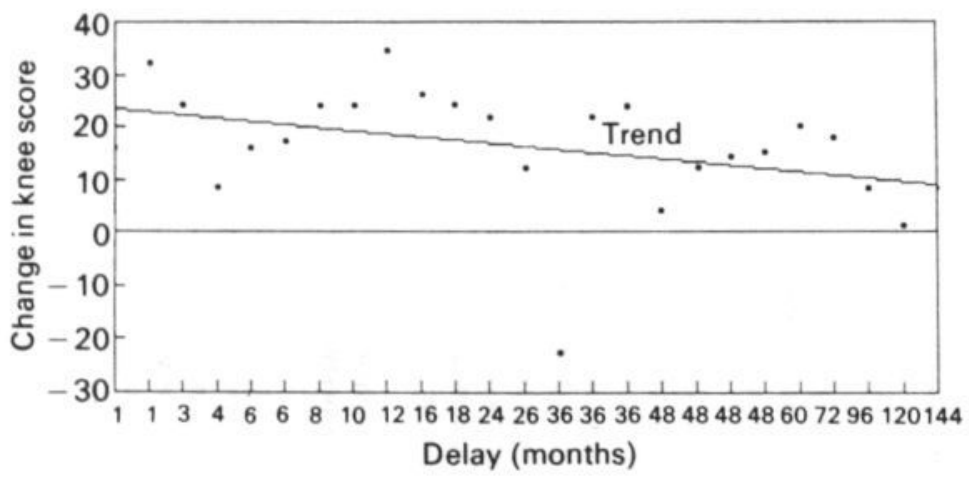

Figure 3. The trend line shows that the result of perichondrial grafting becomes less satisfactory with increasing pre-operative delay.

It also seemed possible that the duration of the lesions before operation might affect the condition of the rest of the articular cartilage of the same joint and so jeopardise the result. Most of our patients had had symptoms for a considerable period of time (mean 37 months, range one month to 12 years). The relation between the pre- 
operative delay and the change in knee score is shown in Figure 2. The Spearman rank correlation coefficient was -0.3822 . Figure 3 shows that with increasing pre-operative delay the result is prejudiced.

We also considered whether the location of the defect (and the graft) might influence the result. This relationship is shown in Figure 4. No significant difference in change of knee score between the grafts was found (Kruskall-Wallis test statistics $=2.96$; level of significance $=0.5650$ ).

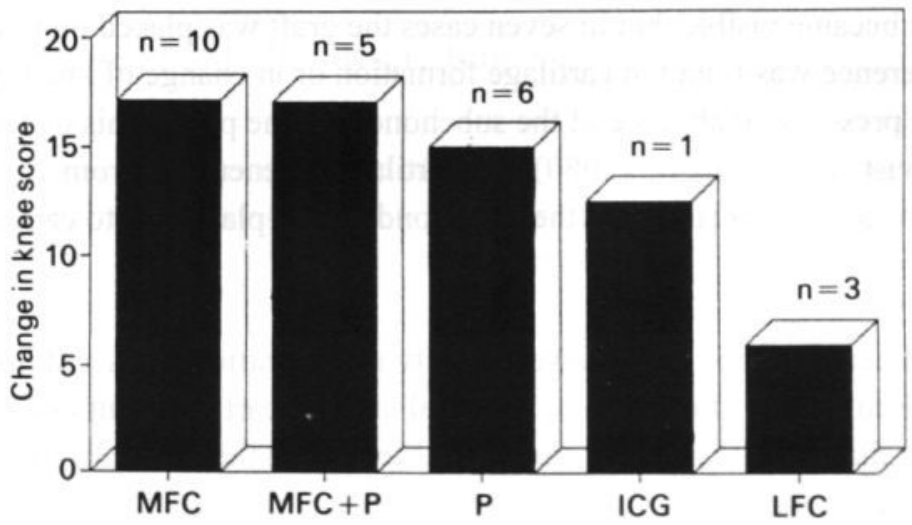

Figure 4. The relationship of the change in knee score to the location of the graft: $\mathrm{MFC}=$ medial femoral condyle; $\mathrm{P}=$ patella: $\mathrm{ICG}=$ intercondylar groove: $\mathrm{LFC}=$ lateral femoral condyle.

\section{DISCUSSION}

Chondral lesions of the knee not only interfere with work and sport but also predispose to arthritis (23). Spontaneous healing is by fibrocartilage which cannot withstand much force. It seemed reasonable, therefore, to try grafting the defect with an autologous piece of perichondrium from a rib, and to anchor it with fibrin glue. This material has been used to reunite nerves, blood vessels, tendons and chondral flake fractures $(85,86)$. For the fixation of cartilage or perichondrial grafts of larger joints, immobilization of the joint is necessary $(73,87,88)$. In our study we followed this by a period of continuous passive motion which is said to promote regeneration of articular cartilage $(82,89)$, though whether this influenced the final result we cannot 
say. Weight-bearing was not allowed during the first three months after operation because the superficial layer of the graft remains soft and vulnerable during this time. Movement was encouraged; but, with a graft in the patellofemoral joint, this movement was limited to $30^{\circ}$.

Arthroscopy in the first few months showed a slightly elevated tissue, resembling articular cartilage, which could be recognised by its white colour and its soft superficial layer. Grafts in the weight-bearing area of the medial femoral condyle were more nearly level with the joint surface after one year than those in low-friction areas or where an old osteochondritic lesion had previously been drilled. Most grafted defects had an intact subchondral bone plate which was only scraped until point haemorrhages became visible, but in seven cases the graft was placed on to cancellous bone. No difference was found in cartilage formation or in change of knee score in relation to the presence or absence of the subchondral bone plate. This differs from the view of Engkvist and Johansson (1980) that cartilage regeneration from perichondrium can only occur when the perichondrium is placed on to cancellous bone (67).

Radiographs taken after one year showed density in the grafted areas and histology showed increased uptake of calcium in the basal layer of cartilage, but ossification of this basal layer did not take place. It must be assumed that the mineralization of the basal layer of newly formed cartilage is increased compared with normal cartilage, as suggested by Plenk and Passl (1980) (90). What impact this increased mineralization will have on the visco-elastic properties of the cartilage and on its durability is still unclear. No relation between the change of knee score and the age of the patient was found as was suggested by Seradge et al. (1984) who grafted joints in the hand and concluded that over the age of 40 the results of perichondrial arthroplasty became worse (72). In our cases the results for young and older patients were not statistically different.

In summary, we concluded that perichondrial grafting of cartilage defects of the knee results in the formation of cartilage and gives good to excellent clinical results. Longterm results of larger numbers of patients are, however, still needed. 


\section{CHAPTER 6}

Long-term results of rib perichondrial grafts for the repair of articular cartilage defects in the human knee

S.J.M. Bouwmeester, J.M.H. Beckers, R. Kuijer, A.J. van der Linden, S.K. Bulstra

International orthopaedics, 21:313-317, 1997 


\section{SUMMARY}

Eighty-eight patients with articular cartilage defects in the knee were treated by perichondrial arthroplasty between 1986 and 1992. An autogenous strip of costal perichondrium was fixed in place with fibrin glue, followed by immobilization, continuous passive motion, and partial weight-bearing. The results were evaluated using the Hospital for Special Surgery Score for knee function, radiographs, arthroscopy and the patient's subjective opinion.

The results after a mean follow-up of 52 months were good in $38 \%$, fair in $8 \%$ and poor in $55 \%$. Previous drilling or shaving of a defect, concomitant osteoarthritis, older age and a long history of complaints proved to be contra-indications. Good results were seen in $91 \%$ of isolated defects. Perichondrial arthroplasty can be beneficial in the repair of cartilage defects. It will reduce symptoms in carefully selected cases, and avoid more extensive operations for osteoarthritis. 


\section{INTRODUCTION}

Full thickness defects of articular cartilage have a poor capacity for repair and the current treatment by shaving or drilling produces fibrocartilage whose biomechanical and biochemical qualities are inferior to normal hyaline cartilage, although symptoms may be reduced $(91,92)$.

Rib perichondrium when transplanted into a cartilage defect produces tissue which closely resembles hyaline cartilage $(65,71,93-95)$, and which may develop into normal hyaline cartilage when placed in a joint $(63,94,96)$. In an animal model, this newly formed cartilage has been shown to have the same visco-elastic properties as hyaline cartilage matched for age and health (74). Neocartilage with histological and biochemical qualities similar to that of normal articular has been reported one year after perichondrial grafting in rabbits $(60,61,66,75,92,97)$. A method of graft fixation was described in 1986 using nontoxic, nonallergic and biodegradabe glue with initial low, but rapidly increasing, adhesive strength (98). This was successful in rabbit's knees and in a small mixed group of patients with chondral and coexisting lesions. The purpose of this paper is to evaluate the long-term results of perichondrial grafting in human knees. This is the first clinical study with a follow-up of more than 4 years (45).

\section{PATIENTS AND METHODS}

From September 1986 to December 1992, 88 patients with an articular cartilage defects were treated by perichondrial arthroplasty in The University Hospital, Maastricht $(45,58,59,63,99)$. The study was approved by the local ethics committee and was performed in accordance with the ethical standards laid down by the 1994 Declaration of Helsinki. Informed consent was obtained before inclusion in the study. One hundred and six cartilage lesions were treated in 88 patients, 40 in the right and 48 in the left knee, in 37 women and 51 men. No exclusion criteria were used, except for age ( $>55$ years). An isolated defect was treated in 70 patients; in 18 patients there were two defects in the same knee. In 13, the perichondrial arthroplasty was combined with an additional procedure, such as anterior cruciate ligament (ACL) repair or a meniscectomy. The mean follow-up was 52 months (range 14 to 80 months). The mean age at operation was 31.3 years (range 15 to 54 years). 
Most perichondrial grafts were placed in the medial and central areas of the patella, in the intercondylar region of the medial femoral condyle and in the weight-bearing area of this condyle (Table I) (98).

Table I. Localisation of articular cartilage defects in 88 patients

\begin{tabular}{lll} 
& Isolated defect & 2 defects \\
\hline$n$ (patients) & 70 & 18 \\
Follow-up & 51 months & 56 months \\
Male & 41 & 10 \\
Female & 29 & 8 \\
Mean age & 30 years & 36 years \\
Patella & 37 & 13 \\
Medial femoral condyle & 28 & 15 \\
Lateral femoral condyle & 2 & 3 \\
Trochlea & 3 & 5 \\
\hline
\end{tabular}

The lesions were traumatic in 31 patients; previous ACL lesions were present in 31, and 12 had osteochondritis dissecans with slight bone loss which had been treated unsuccessfully by drilling. Abnormalities of the menisci were present in 41 patients. In the group of patients with a good Hospital for Special Surgery Score (HSSS), 17/33 had grade 1-2 osteoarthritis at arthroscopy. Of those with a poor score, 18/48 had grade 1-2 osteoarthritis and 5 had grade $3-4$ changes (Table IVb) (100). The size of the cartilage defects varied from $0.3 \mathrm{~cm}^{2}$ to $20.5 \mathrm{~cm}^{2}$.

\section{Operative technique}

The leg was exsanguinated after general anaesthesia with the patient supine. A medial parapatellar incision was used and the patella dislocated laterally, if necessary. The chondral lesion was cleaned with a sharp instrument until bleeding points were visible in the subchondral bone, allowing a better passage for cells. The surrounding cartilage was cut in order to demarcate the lesion. An oblique incision was made over the lower part of the left side of the chest, the fascia of the rectus muscle was split transversely and the muscle in the line of its fibres. The perichondrium was removed, including its chondrogenic layer, from one of the lower costal cartilages. The graft was cut to the 
size of the defect. Two transplants were sometimes needed to cover the entire surface of a large defect.

The graft was fixed with fibrin glue (Tissucol ${ }^{R}$, Immuno, Vienna) (101). The perichondrial graft was placed on the subchondral bone with the chondral side facing the joint; it was firmly pressed to the underlying bone with a wet gauze for one minute, and the knee then moved to assess its fixation. The patella was relocated and the wound closed.

After immobilization for 2 weeks in plaster, continuous passive motion was used for another 2 weeks (89). Movement was encouraged, but for grafted lesions of the patella and the intercondylar groove flexion was limited to $30^{\circ}$. Four weeks after operation, the patients were allowed up non-weight-bearing and active movements encouraged. Full weight-bearing was begun 3 months after the operation (69).

After a mean follow-up of 52 months (range 14 to 80 months), the results were evaluated by the HSSS, radiographs, a visual analogue scale and arthroscopy one year after the operation. The patients were seen at intervals of 4,8 and 12 months and thereafter at 11/2,2, 3, 4 years and later. No histochemical or biochemical assessment of the repair tissue was undertaken because biopsy could not be justified on ethical grounds.

We studied the correlations between the success rate and the site of the lesion, the size of the graft, calcification of the graft seen on radiographs, coexisting abnormalities in the knee and combinations of treatment in relation to the HSSS score.

A result was rated good if the score was $>85$ and the arthroscopic appearances were good. Failure was a score of $<75$ whether the arthroscopy was good or bad, and so was the score $<75$ in combination with a bad result at arthroscopy or with a need to reoperate. Any loosening of the graft, outgrowth above the surrounding tissue or progressive osteoarthritis seen at arthroscopy were failures. A score of 75-84 was fair.

A second group of 14/88 patients were operated on from 1989 to 1992 using a different technique in which the graft was perforated in order to avoid haematoma formation. This group were also given indomethacin $25 \mathrm{mg} 3$ times a day from the day before operation for 2 weeks to minimize calcification in the graft.

The mean follow-up was 14.5 months (range 6 to 29 months). 


\section{RESULTS}

In $33 / 88(38 \%)$ the result was excellent or good; $7(8 \%)$ were fair and $48(55 \%)$ were failures, mainly because of loosening of the graft seen at arthrosccopy (Table II). The fair group have been omitted from the rest of the tables for clarity.

\section{Table II.}

Results H.S.S.S. $(n=88)$

\begin{tabular}{llrr}
\hline & & & \\
& Points & \multicolumn{1}{c}{$n$} & \multicolumn{1}{c}{$\%$} \\
\hline Excellent/good & $85-100$ & 33 & $38 \%$ \\
Fair & $75-84$ & 7 & $8 \%$ \\
Poor and & $<75$ & 10 & \\
reoperation/arthroscopic failure & 38 & $55 \%$ \\
\hline
\end{tabular}

In the whole group, $27 \%$ of the grafts were lost (24/88) (Table III) and this was significantly worse for grafts on the patella ( $p<0.05$, chi-squared test) (Table IVc). In $10 / 88$ patients $(11 \%)$, failure was caused by growth of the graft above the surrounding cartilage which felt hard at arthroscopy, and occurred most often when the patella was grafted (7/37).

Progressive osteoarthritis, as seen at arthroscopy one year after operation, occurred in $4 / 88$ patients, and 3 of these had more than one graft. Isolated patella grafts failed in $23 / 37$, and so did $10 / 28$ of the medial femoral condyle grafts (Table III). The highest rate of failure (14/18) was in double perichondrial grafts.

\section{Table III.}

Failures and localisation of the graft $(n=48)$

\begin{tabular}{lll} 
& $n$ & $\%$ \\
\hline Patella & $23 / 37$ & $62 \%$ \\
Medial femoral condyle & $10 / 28$ & $36 \%$ \\
Combinations & $14 / 18$ & $78 \%$ \\
Trochlea & $1 / 3$ & $33 \%$ \\
\hline
\end{tabular}

Radiographs showed calcification within the graft one or 2 months after operation. Excluding the arthroscopic failures and those that were operated on again, calcification was seen in 25/47; in 22 there was no calcification (Table V). Instability and previous meniscectomy were not detrimental to the clinical results (Table IVa). 
Previous drilling or shaving of the defect, age above 40 years and a long period of complaints before operation influenced the results adversely (Table IVa, b). When more than one graft was used, the results were poor $(p<0.05)$. Osteoarthritis above grade 2 (fibrillation) in other parts of the knee at arthroscopy proved an absolute contra-indication for grafting (Table IVb). Seven patients (7/12) with osteochondritis dissecans with only slight bone loss had good results. The size of the lesion had an adverse effect, but this was not significant; in 48 with a poor result, the average size of the lesion was $3.97 \mathrm{~cm}^{2}$, compared with $3.17 \mathrm{~cm}^{2}$ in 33 who had a good result.

\section{Table IVa.}

Results of perichondrial arthroplasty

\begin{tabular}{lccccc}
\hline & Good & \multicolumn{3}{l}{ Poor } \\
& $n=33$ & & $n=48$ & Sig. \\
\hline 1 grafts & 30 & $91 \%$ & 34 & $71 \%$ & $*$ \\
2 grafts & 3 & $9 \%$ & 14 & $29 \%$ & $*$ \\
Surface cm & 2,17 & $0,4-20,5$ & 3,97 & $0,8-15$ & N.S. \\
Duration of complaints (months) & 40,2 & $1-120$ & 52,5 & $5-240$ & N.S. \\
Age at operation (years) & 28 & $17-41$ & 32,6 & $15-48$ & $\#$ \\
\hline
\end{tabular}

$*=p<0.05 \#=p<0.025$

\section{Table IVb.}

Results of perichondrial arthroplasty in relation to the cause of the defect in 88 patients

\begin{tabular}{|c|c|c|c|}
\hline & $\begin{array}{l}\text { Good } \\
n=33\end{array}$ & $\begin{array}{l}\text { Poor } \\
n=48\end{array}$ & Sig. \\
\hline Trauma & 15 & 15 & N.S. \\
\hline Osteochondritis dissecans & 7 & 4 & N.S. \\
\hline Previous debridement & 9 & 22 & N.S. \\
\hline \multicolumn{4}{|l|}{ Osteoarthritis } \\
\hline Gr 0 & 16 & 25 & N.S. \\
\hline Gr $1-2$ & 17 & 18 & N.S. \\
\hline Gr $3-4$ & 0 & 5 & N.S. \\
\hline
\end{tabular}

$p<0.05$ significant 
Table IVc.

Results of isolated defects in

patella and medial femoral condyle

\begin{tabular}{lll} 
& Good & Poor \\
\hline Patella & 12 & 23 \\
Medial femoral condyle & 15 & 10 \\
\hline$p<0.05$ & &
\end{tabular}

The 14/88 patients given indomethacin for prophylaxis had a reduced incidence of calcification in the graft, their mean follow-up was 14.5 months (range 6 to 29 months). Two patients in this group were lost and excluded; $2 / 12$ showed calcification. Of 25 calcified grafts, 23 had not received indomethacin (Table V). These differences were statistically significant $(p<0.005$, using chi-squared test with the Yates correction).

\section{Table V.}

Effects of indomethacin (indo) on calcification (calc)

\begin{tabular}{lll}
\hline & + calc & - calc \\
\hline + indo & 2 & 10 \\
- indo & 23 & 12 \\
\hline
\end{tabular}

$p<0.005$

\section{DISCUSSION}

Chondral lesions in the knee interfere with work and sport, and predipose to osteoarthritis (23). Spontaneous healing is poor, and shaving and drilling the lesions result in fibrocartilage which is mechanically inferior to articular cartilage $(91,97)$. Rib perichondrium has the potential to differentiate into cartilage with similar properties to hyaline cartilage $(75,94,96,99)$.

Our study shows that the success of this procedure depends on the selection of the patients. Contra-indications for the procedure are more than one defect, previous debridement operations, a long history of symptoms, age over 40 years, and grade 2 or worse osteoarthritis in the rest of the knee. Grafting the patella was less successful because of the mechanical demands and pressure in this area. Good or excellent results were seen with an isolated traumatic defect of the medial femoral condyle in patients under 40 years. 
Fibrin glue provides sufficient immediate fixation, but we used immobilization to ensure that this fixation was not disturbed $(101,102)$.

Continuous passive motion was used because of its beneficial effect on cartilage regeneration (89).

During the first 3 months weight-bearing was not allowed because the superficial part of the graft was assumed to be soft. Movement was limited to $30^{\circ}$ for patellar grafts, but otherwise was encouraged.

The calcification seen in radiographs may be due to mineralization of the base of newly formed cartilage which could have an adverse effect on the visco-elastic properties of the new cartilage and its durability (102). We considered that this increased mineralization was a cause of loosening and the raised hard surface which was found in some of our cases. Indomethacin was shown to prevent calcification and its use should improve the results. Perforating the graft reduced the risk of loosening by preventing haematoma formation.

The design of this study allowed us to establish the indications for perichondrial grafting in the knee. The best results are in patients under 40 years with isolated defects, and without osteoarthritis elsewhere in the joint. Further work to improve fixation and to prevent calcification was started. 


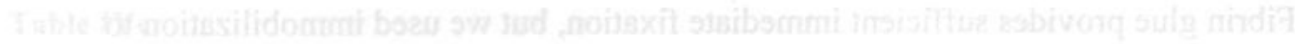

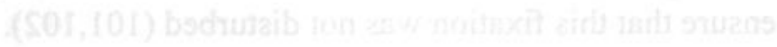

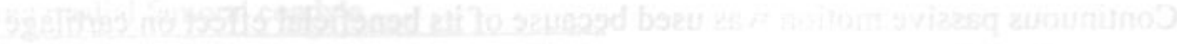

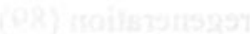

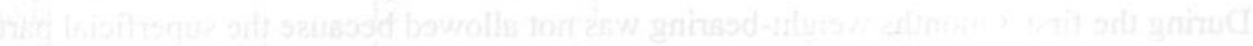

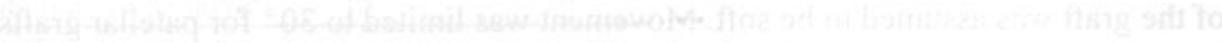




\section{CHAPTER 7}

\section{The polymer Polyactive ${ }^{\mathrm{TM}}$ as a bone-filling substance: an experimental study in rabbits}

R. Kuijer, S.J.M. Bouwmeester, M.M.W.E. Drees, D.A.M. Surtel, E.A.W. TerwindtRouwenhorst, A.J. van der Linden, C.A. van Blitterswijk, S.K. Bulstra

Journal of Materials Science: Materials in Medicine, 9:449-455, 1998 


\section{SUMMARY}

The biocompatible, osteoconductive and resorbable polymer Polyactive ${ }^{\mathrm{TM}}(\mathrm{PA})$ was investigated for its performance as a bone-graft substitute. The model consisted of a 4 $\mathrm{mm}$ borehole, $1.5 \mathrm{~cm}$ distal of the major trochanter in both femurs of a rabbit, of which one was filled with a cylinder of porous PA. The other borehole was left untreated. PA70/30 and PA60/40 were investigated, both before and after being incubated with allogenic bone marrow. Analyses were performed after 4, 8, 26 and 52 weeks and comprised dual energy X-ray absorptiometry (DXA) and image analysis of histological sections.

DXA revealed an increased bone mineral density in the filled defects compared to the controls, both at the defect and immediately proximal and distal of the defect. Histology showed that gap-bridging had occurred within 8 weeks, with $80 \%-90 \%$ of the pores of PA70/30 and PA60/40 occupied by new bone, and an intimate bone-PA contact. PA70/30 seemed to be more suitable compared to PA60/40, in that the highest amount of bone was formed within the shortest period of time. Incubation of PA with allogenic bone marrow resulted in inflammatory reactions at the sites of implantation, which delayed bone growth, but did not prevent it. It was concluded that PA70/30 and PA60/40 are suitable bone-graft substitutes. 


\section{INTRODUCTION}

Spontaneous repair of cortical bone defects, like screw holes, is limited in humans (103). Therefore, these defects present a considerable risk of refracture with an incidence between $1 \%$ and $8 \%$ in forearm, tibia, femur or spine (104-107).

In this study a $4 \mathrm{~mm}$ defect in the femur of a rabbit, comparable to a screw hole, was used to compare spontaneous, new bone formation with bone formation after implantation of the biocompatible and osteoconductive polymer Polyactive ${ }^{\mathrm{TM}}$. A previous pilot study revealed that the process of spontaneous repair of such a bore hole in the femur of a rabbit was not able to gap the defect within 8 weeks (unpublished work). Therefore, this model appears to be suitable for this study.

Polyactive is a segmented copolymer of polyethylene oxide terephthalate and polybutylene terephthalate (PEO/PBT), which was initially used to design a synthetic tympanic membrane. The material has been proven to be biocompatible and osteoconductive, and appeared to be a bone-bonding material $(52,108-111)$. In addition PA is easy to handle and biodegradable $(111,112)$. Varying the ratio PEO over PBT results in materials with different properties. A relatively high concentration of PEO proved to be essential for the bone-bonding properties of the material. The bone-bonding mechanism of the material appeared to be related to the capacity of the material to absorb selectively calcium and phosphate $(51,110,113)$.

The kinetics of bone growth inside the pores of the cylinders, both at the level of the cortex and in the medullary cavity, were investigated. PA60/40 was tested because of its slightly better mechanical properties than PA70/30. Furthermore, it was tested whether the bone growth in and near the implant could be enhanced by incorporating osteoinductive factors present in trabecular bone and bone marrow in the cylinders, as is seen when a polymer is implanted subcutaneously (114-116).

Because the osteoconductivity of Polyactive is caused by the ability of the material to absorb selectively calcium and phosphate $(51,110,113)$, and incubation of Polyactive with bone marrow probably results in "pre-calcification" of the material, implantation of incubated Polyactive should also lead to enhanced bone formation. 


\section{MATERIALS AND METHODS}

Polyactive porous PA cylinders of composition (PEO/PBT) 70/30 and 60/40 used in this study were manufactured and supplied by HC Implants bv, Leiden, The Netherlands. The pores were interconnected. The average pore diameter was $300 \pm$ $150 \mu \mathrm{m}$; the diameter of the interpore connections was $100 \pm 50 \mu \mathrm{m}$. These diameters were shown to be optimal for growth of bone $(51,117,118)$. The cylinders were $4 \mathrm{~mm}$ in diameter and $5 \mathrm{~mm}$ long. Half the number of cylinders were incubated with allogenic bone marrow: bone marrow was harvested from the femur of one New Zealand White rabbit, not belonging to the animals in this study, and diluted with Dulbecco's modified Eagle medium (DMEM culture medium) (1:1). PA cylinders were incubated for $24 \mathrm{~h}$ at $37^{\circ} \mathrm{C}$, then briefly washed in phosphate-buffered saline and freeze dried in order to kill allogenic cells and to shrink the implants to their original dimensions. All PA cylinders were sterilized by gamma irradiation $(25 \mathrm{kGy})$ at Gammaster, Ede, The Netherlands.

For this animal experiment, approval was obtained from the local committee for animal experiments. Female New Zealand White rabbits (128) were used, each about 6 months old, weighing between 3.5 and $4.5 \mathrm{~kg}$. The rabbits were randomized and, at the time of operation, anaesthetized using ketamine hydrochloride $\left(100 \mathrm{mg} \mathrm{kg}^{-1}\right)$ and diazepam $\left(8 \mathrm{mg} \mathrm{kg}^{-1}\right)$. Both femurs were exposed laterally. The periosteum was put aside and, approximately $1.5 \mathrm{~cm}$ below the major trochanter, a borehole of $4 \mathrm{~mm}$ diameter was made. In the right femur, a PA cylinder was implanted; the borehole in the left femur was left untreated. Four groups of 32 rabbits were followed for, respectively, 4, 8, 26 and 52 weeks. Of the 32 rabbits, eight received a cylinder of Polyactive 70/30 (PA70/30); eight a cylinder of PA70/30 impregnated with bonemarrow (PA70/30BM); eight a cylinder of PA60/40 and eight a cylinder of PA60/40 which was incubated with bone marrow (PA60/40BM) (Table I). The animals were housed in groups at a farm in cages of $4 \mathrm{~m} \mathrm{x} 4 \mathrm{~m}$.

The animals were killed using an overdose of thiopental. Both femurs were dissected, placed in sterile PBS and transported to the dual energy X-ray absorbtiometer (DXA) (DPX 560, Lunar). The exact location of the borehole was measured relative to the femoral head and trochanter major. DXA scans were made in the lateral - medial direction. The bone mineral density (BMD, $\mathrm{g} \mathrm{cm}^{-2}$ ) was assessed in three regions of interest (ROI). Three ROIs of $0.2 \mathrm{~mm}^{2}$ adjacent to each other were placed proximal to the defect, over the defect and distal to the defect, respectively. One $0.06 \mathrm{~mm}^{2} \mathrm{ROI}$ was placed in the centre of the $0.2 \mathrm{~mm}^{2} \mathrm{ROI}$ that was placed over the defect. Data 
given are from the $0.06 \mathrm{~mm}^{2} \mathrm{ROI}$ in the centre of the defect and both the $0.2 \mathrm{~mm}^{2}$ ROI's proximal and distal of the defect. Then segments of the femur containing the borehole were fixed in $4 \%$ phosphate-buffered formaldehyde. Part of these segments were dehydrated through a series of acetone solutions and embedded in methylmetacrylate. Sections of $10 \mu \mathrm{m}$ were cut using an especially developed histological inner lock diamond saw microtome cutting system (Leiden, The Netherlands) and stained with methylene blue and basic fuchsine (119).

Other segments were decalcified with a $10 \%$ solution of ethylenediaminetetraacetic acid (EDTA), dehydrated and embedded in glycol methacrylate. Sections of $4 \mu \mathrm{m}$ were stained with trichrome according to Gomori.

Image analysis (Quantimet 570C, Leica Cambridge Ltd, Cambridge, UK) was used to determine the course of the area occupied by implant material, and the percentage tissue occupied by exudate cells/fibrous tissue, and bone. Also, the percentage of the outline of the PA implant in intimate contact with new bone was determined. This is a measure for bone-bonding capacity of the biomaterials. The total area of the pores represented about $40 \%-50 \%$ of the field measured, and was taken as $100 \%$.

For statistical analysis, data were compared with one-way ANOVA and Student's $t$ test.

\section{RESULTS}

From the 128 rabbits that were operated, 21 died or had to be killed before the end of the experiment (Table I). Cause of death was either a pneumonia or an unknown cause not related to the implants. One rabbit had a fractured femur at the level of the bore hole and four rabbits had developed an osteomyelitis.

\section{Table I.}

Distribution of rabbits over 16 groups: four groups of 32 rabbits had four different forms of PA implanted and were followed for 4, 8, 26 and 52 weeks. The data indicate the number of rabbits included in the study; the number of rabbits that were originally operated on is given in parentheses

\begin{tabular}{lllll}
\hline & 4 weeks & 8 weeks & 26 weeks & 52 weeks \\
\hline PA70/30 & $8(8)$ & $8(8)$ & $7(8)$ & $7(8)$ \\
PA70/30BM & $3(8)$ & $7(8)$ & $7(8)$ & $6(8)$ \\
PA60/40 & $8(8)$ & $7(8)$ & $7(8)$ & $6(9)$ \\
PA60/40BM & $6(8)$ & $8(8)$ & $6(8)$ & $6(7)$ \\
\hline
\end{tabular}




\section{DXA}

Both experimental and control femurs were subjected to DXA analysis. With the ROI over the defect, after 4 weeks implantation the BMD was $0.073 \mathrm{~g} \mathrm{~cm}^{-2}(18.2 \%$; $p<0.02$ ) higher when PA70/30 was implanted as compared to the contralateral control site (Table II).

For the other implants, in general the experimental sites at 4 weeks implantation time contained $10 \%-20 \%$ more mineral than the control site, but the differences were not significant. After longer implantation times, differences between experimental and control sites had not changed: the experimental site contained $10 \%-25 \%$ more mineral then the control site. Occasionally the differences were significant (Table II).

\section{Table II.}

DXA analysis: relative differences between experimental side and control side assessed in an ROI of $0.06 \mathrm{~mm}^{2}$ over the defect, an ROI of $0.2 \mathrm{~mm}^{2}$ proximal to the defect and an ROI of $0.2 \mathrm{~mm}^{2}$ distal to the defect. Data from experimental and control sides were compared using the Student's $t$ test for paired data

\begin{tabular}{|c|c|c|c|c|c|c|c|c|c|c|c|c|}
\hline & \multicolumn{2}{|l|}{$4 \mathrm{wk}$} & \multicolumn{3}{|c|}{$8 \mathrm{wk}$} & \multirow[b]{2}{*}{$\mathrm{P}$} & \multicolumn{2}{|c|}{$26 \mathrm{wk}$} & \multicolumn{4}{|c|}{$52 \mathrm{wk}$} \\
\hline & $\%$ & $n$ & $\mathrm{P}$ & $\%$ & $n$ & & $\%$ & $n$ & $\mathrm{P}$ & $\%$ & $n$ & $\mathrm{P}$ \\
\hline 0.06 defect & & & & & & & & & & & & \\
\hline PA70/30 & 18.2 & 7 & ** & 11.6 & 5 & ns & 15.2 & 7 & ns & 14.3 & 6 & ns \\
\hline PA70/30BM & 9 & 5 & ns & 21.8 & 5 & $*$ & 26.3 & 7 & ** & 0.8 & 5 & ns \\
\hline PA60/40 & 15 & 7 & ns & -8.6 & 5 & ns & 19.6 & 8 & $* *$ & 2.3 & 5 & ns \\
\hline PA60/40BM & 20.1 & 4 & ns & -1.2 & 3 & ns & 14.8 & 6 & ns & 19.8 & 6 & ns \\
\hline 0.2 proximal & & & & & & & & & & & & \\
\hline PA70/30 & 12.4 & 7 & * & 18.5 & 5 & $*$ & 9.3 & 7 & $*$ & 8.6 & 6 & $*$ \\
\hline PA70/30BM & 22.0 & 5 & $*$ & 4.0 & 5 & ns & 16.5 & 7 & $* *$ & -2.2 & 5 & ns \\
\hline PA60/40 & 17.0 & 7 & ns & 6.2 & 5 & ns & 11.6 & 8 & ns & -5.8 & 5 & ns \\
\hline PA60/40BM & 17.2 & 5 & ns & 14.9 & 3 & ns & 14.5 & 6 & ns & 5.6 & 6 & ns \\
\hline 0.2 distal & & & & & & & & & & & & \\
\hline PA70/30 & 24.1 & 7 & $* *$ & 22.4 & 5 & ns & 8.1 & 7 & $*$ & -2.8 & 6 & ns \\
\hline PA70/30BM & 19.1 & 5 & ns & 10.5 & 5 & ns & 7.5 & 7 & ns & 1.3 & 5 & ns \\
\hline PA60/40 & 14 & 7 & $*$ & 14 & 5 & ns & 8.2 & 8 & $*$ & 2.5 & 5 & ns \\
\hline PA60/40BM & 19.4 & 5 & $* *$ & 19.3 & 3 & ns & 5.4 & 6 & ns & 18.5 & 6 & $* *$ \\
\hline
\end{tabular}

${ }^{*}=p<0.05 ;^{* *}=p<0.02$

The BMD was also assessed proximal and distal to the defect. Proximal to the defect, the BMD at the experimental site was $10 \%-20 \%$ higher then at the control site after 4 
and 8 weeks. After 26 weeks implantation, the experimental site contained 5\%-10\% more mineral then the control site and after 52 weeks the differences were eliminated. The same was seen just distal to the defect.

The BMD at sites where PA pre-incubated with bone marrow was implanted showed larger variability than when PA without bone marrow was implanted. DXA analyses did not reveal differences between PA70/30 and PA60/40, whether or not these materials were pre-incubated with bone marrow.

\section{Histology}

Cortex of the femur: At 4 weeks after implantation of the PA70/30 and the PA60/40 cylinders, the pores of the plugs within the cortex of the femur were mainly filled with bone and cell-dense fibrous tissue. Bone growth was from the edges of the cylinder, where the PA was in contact with the cortical bone, towards the centre. Polyactive served as scaffold for deposition of bone (Fig. 1a).

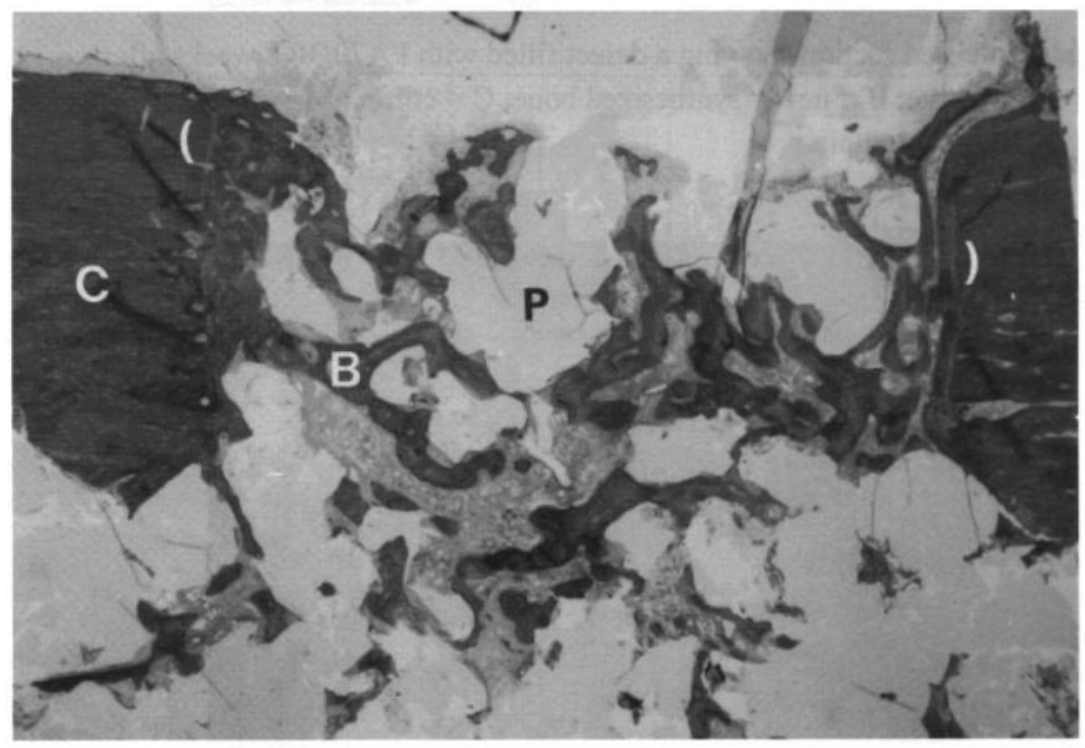

Figure 1a. Histological sections of bone defects filled with Polyactive and after spontaneous "repair". Undecalcified sections $(10 \mu \mathrm{m})$ were prepared using a modified innerlock diamond saw. These sections were stained with methylene blue and basic fuchsine. Decalcified sections were stained with trichrome according to Gomori. A decalcified section showing a defect filled with PA70/30, 4 weeks after implantation. $\mathrm{P}=$ Polyactive; $\mathrm{B}=$ newly synthesized bone; $\mathrm{C}=\operatorname{cortex} ;()=$ the margins of the borehole. 


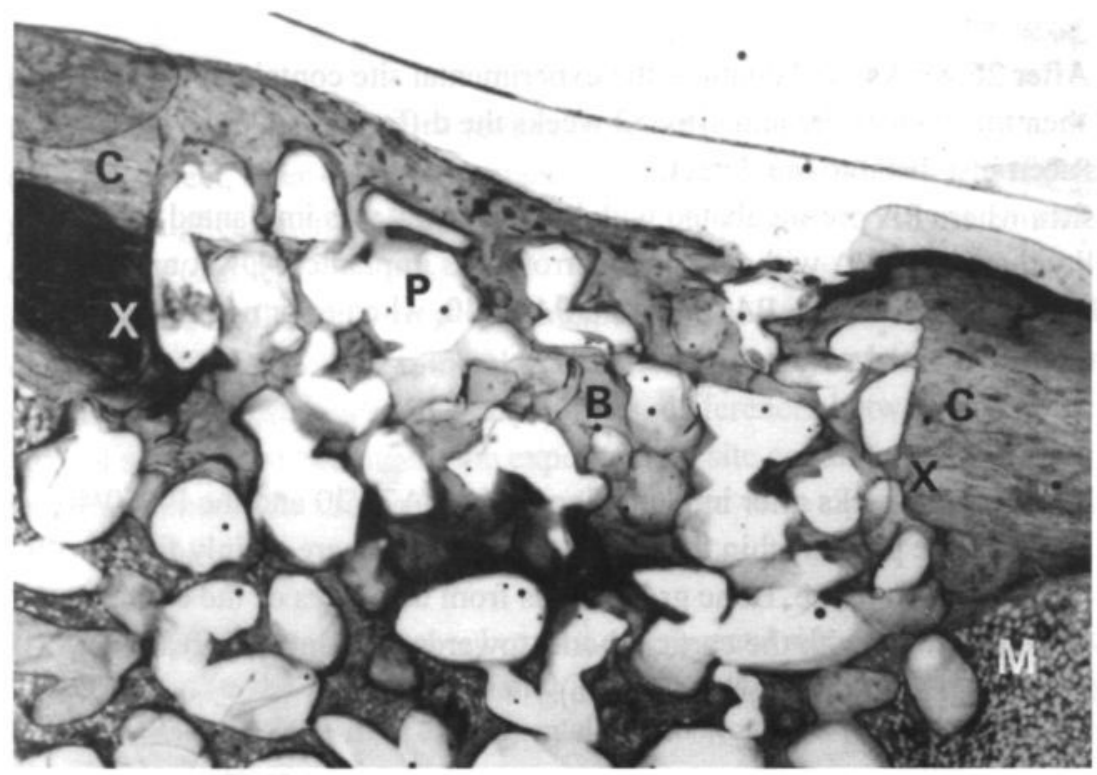

Figure 1b. An undecalcified section showing a defect filled with PA70/30 8 weeks after implantation; $\mathrm{P}=$ Polyactive; $\mathrm{B}=$ newly synthesized bone; $\mathrm{C}=$ cortex; $\mathrm{M}=$ marrow cavity; $(\mathrm{XX})=$ the margins of the borehole.

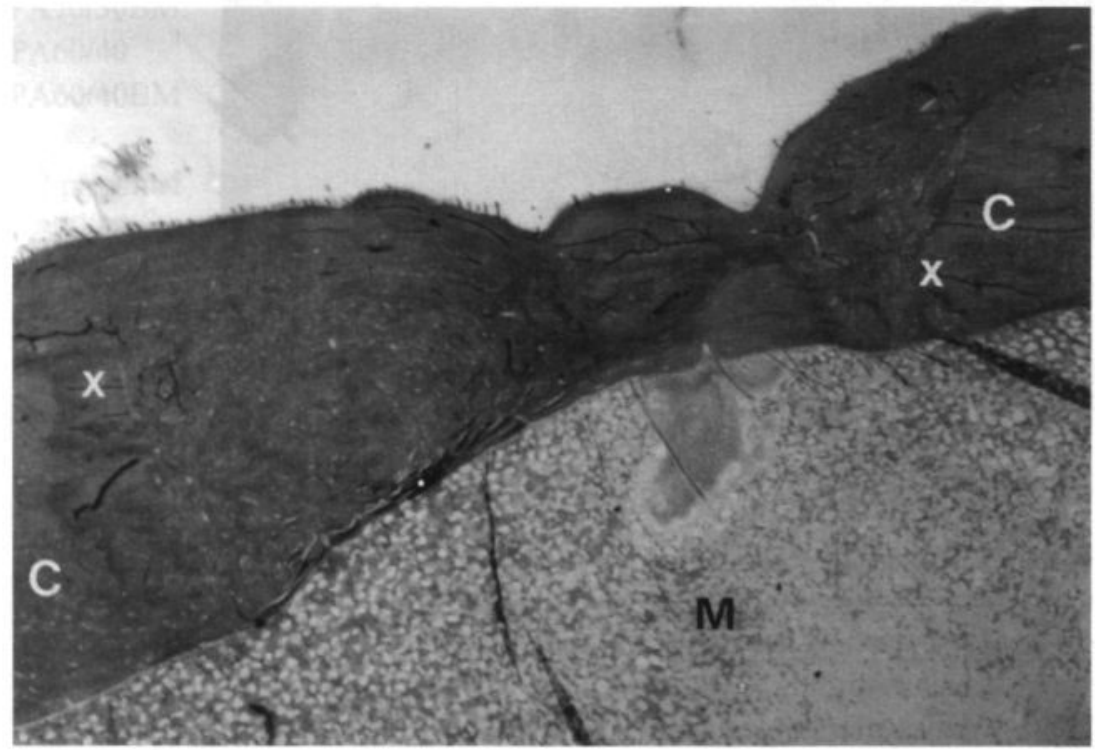

Figure 1c. An undecalcified section showing a control defect 52 weeks after transplantation. $\mathrm{C}=\operatorname{cortex} ; \mathrm{M}=$ marrow cavity; $(\mathrm{xx})=$ the margins of the borehole. 
Assessment of the percentage of pore surface occupied by bone revealed that after 4 weeks, PA70/30 contained $53 \%$ bone. This was more than for PA60/40 cylinders (40\%; not significant) and for PA70/30BM or PA60/40BM cylinders ( $27 \%$ and $8 \%$, respectively; significant) (Fig. 2).

After 8 weeks, $70 \%-95 \%$ of the total surface area of the pores of all types of PA cylinders were filled with newly synthesized calcified bone (Figs 1b, 2). Again, pores of PA70/30 or PA60/40 plugs contained significantly more bone $(95 \%$ and $91 \%$ respectively) than pores of PA70/30BM or PA60/40BM cylinders, respectively (82\% and $66 \%$ ).

After 26 weeks, the pores in PA70/30, PA70/30BM and PA60/40 were filled to the same extent, approximately $87 \%$, with new bone, while $69 \%$ of the pores of PA60/40BM was occupied with bone at that time.

After 52 weeks, in all types of PA, over $83 \%$ of the total surface area of the pores were filled with new bone (Fig. 2). The remaining part of the pores was filled with fibrous connective tissue and bone marrow.

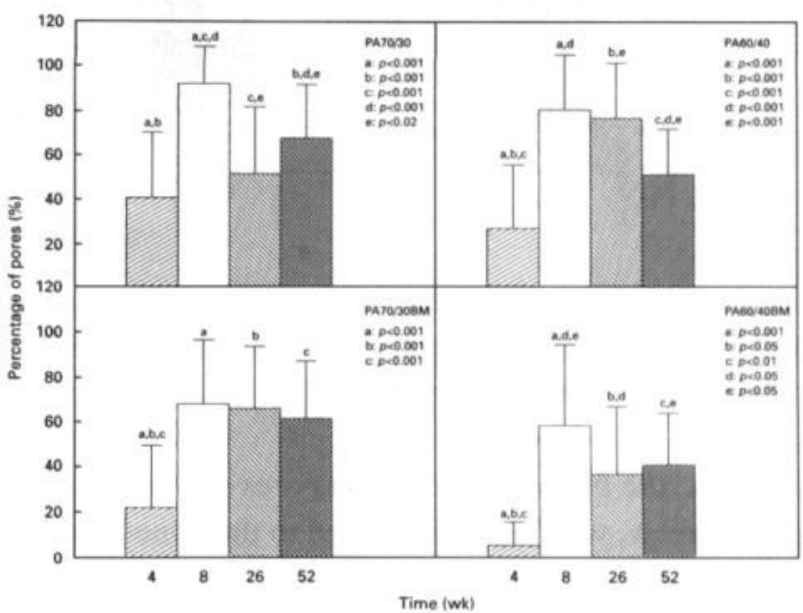

Figure 2. The percentage of the pores of different Polyactives filled with bone within the cortical gap at different implantation times. Bars that share the same letter (within one quarter of the figure) differ significantly (Student's $t$-test $p<0.05$ ).

Between $5 \%$ and $90 \%$ of the PA surface was in contact with bone, depending on the kind of PA and the implantation period (Fig. 3). In general, a higher percentage of the surface of PA implants that had not been pre-incubated with bone marrow, was in intimate contact with bone, as compared with implants that were pre-incubated. 
PA70/30 showed the highest area of intimate contact with bone after 8 weeks (92.5\%). At longer implantation times the area of intimate contact decreased to $<80 \%$ (Fig. 3). PA cylinders that were pre-incubated with allogenic bone marrow, evoked an inflammatory reaction characterized by infiltrations of polymorphonuclear and mononuclear cells (data not shown).

Between different animals there were large fluctuations regarding inflammation signs.

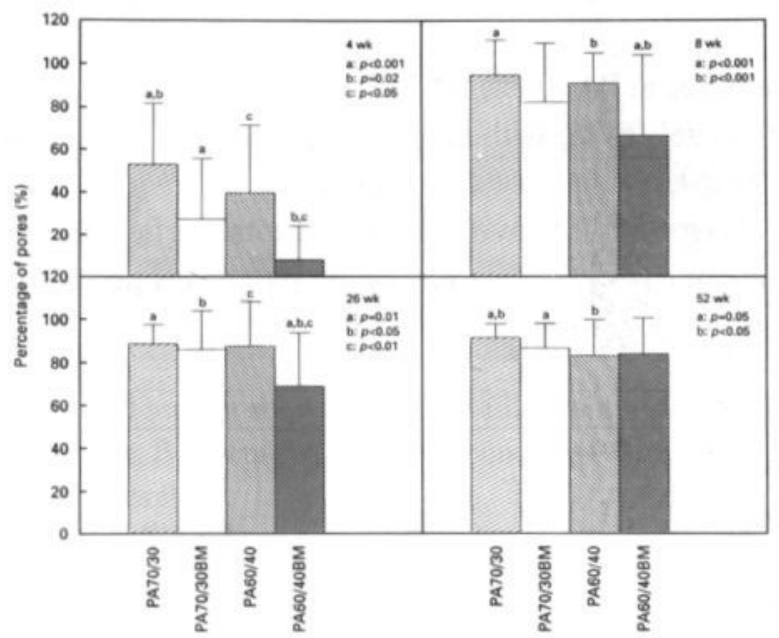

Figure 3. The percentage of Polyactive in direct contact with bone within the cortex of the femur versus the graft material. Bars that share the same letter (within one quarter of the figure) differ significantly (Student's $t$-test, $p<0.05$ ).

At all implantation times, the bone content of the pores of the PA that had been preincubated with bone marrow, was lower compared to the bone content of the nontreated PA cylinders. However, after 1 year, differences in bone content between implants that had been pre-incubated and those that had not been pre-incubated were no longer significant.

Repair of the defect at the control site showed large variations. After 4 or 8 weeks, defects were still visible and only limited filling of the defect with new bone had occurred. After 52 weeks, control defects in general were almost fully repaired (Fig. 1c).

Medullary cavity: The implants extended into the medullary canal. The PA implants were predominantly filled with bone marrow and stroma. At 4 weeks after the 
implantation, $17 \%$ of the pores of PA70/30 were filled with newly synthesized bone (Fig. 1d, Table III). In the other types of PA implants the amount of bone was $10 \%$ or less after that implantation period. Of the pores of PA 70/30, $6 \%$ were filled with bone after 8 weeks, and $<1 \%$ after 26 and 52 weeks. In all other PA implants, the amount of bone decreased with time to zero after 26 weeks (Table II).

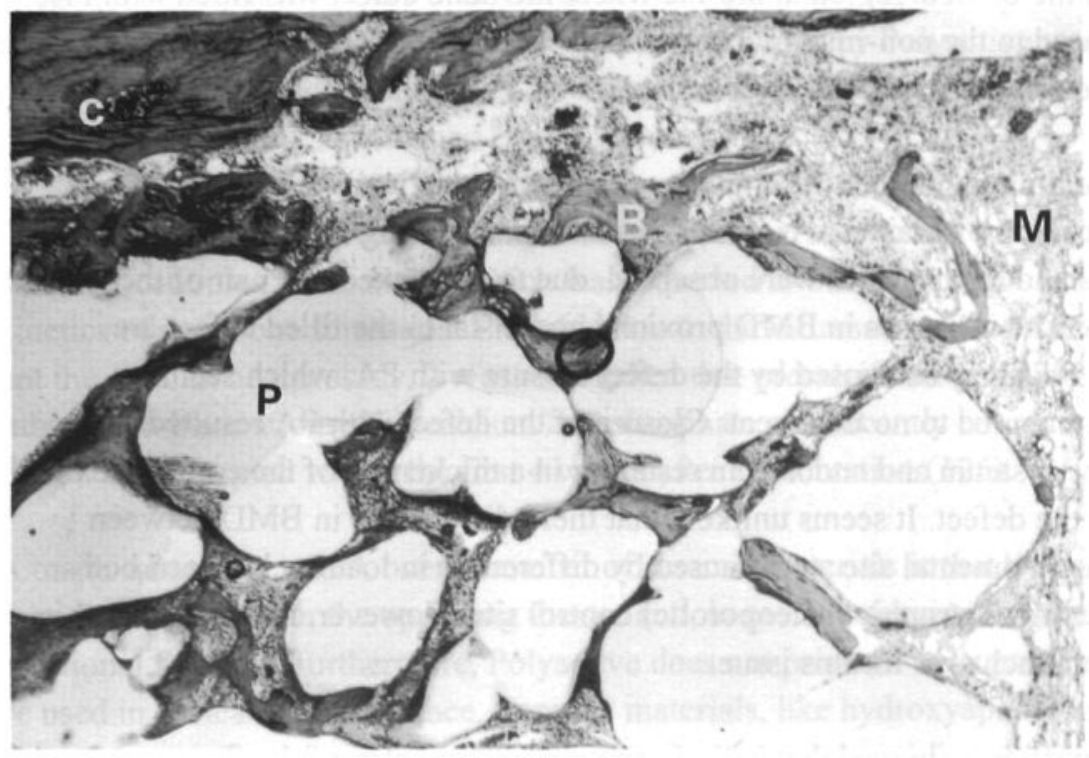

Figure 1d. A decalcified section showing bone present in the pores of PA70/30 in the medullary cavity after 4 weeks of implantation. $\mathrm{P}=$ Polyactive; $\mathrm{B}=$ newly synthesized bone; $\mathrm{c}=$ cortex; $\mathrm{M}=$ marrow cavity.

\section{Table III.}

Percentage bone in pores of Polyactive inside the medullary cavity at different implantation times

$\begin{array}{llll}\text { PA70/30 } & \text { PA70/30B } & \text { PA60/40 } & \text { PA60/40B }\end{array}$

Implantation

\begin{tabular}{|c|c|c|c|c|c|c|c|c|}
\hline time (wk) & (\%) & S.D. ${ }^{\mathrm{a}}$ & (\%) & S.D. ${ }^{\mathrm{a}}$ & $(\%)$ & S.D. ${ }^{\mathrm{a}}$ & (\%) & S.D." \\
\hline 4 & 17.4 & 10.1 & 4.1 & 2.0 & 3.9 & 2.5 & 2.3 & 0.3 \\
\hline 8 & 6.3 & 4.7 & 0.6 & 0.4 & 1.0 & 0.8 & 2.5 & 1.3 \\
\hline 26 & 0.9 & 0.8 & 2.4 & 1.8 & 0.1 & 1.1 & 2.4 & 0.8 \\
\hline 52 & 0.03 & 0.04 & 0.03 & 0.04 & 0 & 0 & 0.07 & 0.12 \\
\hline
\end{tabular}

${ }^{a}$ S.D. = standard deviation. 


\section{DISCUSSION}

In this study, the biocompatible and bone-bonding polymer Polyactive ${ }^{\mathrm{TM}}$ was tested for its performance as a bone-graft substitute in a rabbit model. The results after 4,8 , 26 and 52 weeks were analysed by DXA and image analysis of histological sections. The results obtained after analysis of the DXA data were indicative of enhanced bone formation in the cortical region at the site where the bone defect was filled with PA, when compared to the non-implant control site. We were not able to measure the $\mathrm{BMD}$ at time zero, due to technical problems.

Owing to the limited number of samples, not always statistically significant differences could be obtained. As time progressed, decreasing differences between experimental and control sites were observed, due to spontaneous repair of the control bone defects. The increases in BMD proximal and distal to the filled defect are noteworthy. This may be caused by the defect closure with PA, which seems favourable compared to no treatment. Closure of the defect with PA resulted in a reaction of periosteum and endosteum resulting in a thickening of the cortex proximal and distal to the defect. It seems unlikely that these differences in BMD between control and experimental site were caused by differences in loading between both hind-legs, i.e. more atrophic (osteoporotic) control site. However, the data from this study are not conclusive for this issue.

The histological data showed that bone formation in the cortex of the femur proceeded from the periphery of the PA cylinders towards the centre. This is indicative for bioactivity of PA. Within 8 weeks, the defect was bridged by new calcified bone which filled the pores of the PA almost completely. At this time, an intimate contact was seen between bone and PA at the light microscope level, which is indicative of the bone-bonding properties of these materials $(51,52,108,116,120)$.

The decrease in bone-PA contact with time is probably caused by the process of degradation of PA and by the normal process of bone turnover.

Bone was initially formed in the pores of the PA plugs at the level of both the cortex and the medullary cavity. After 8 weeks, however, the bone inside the medullary cavity had almost completely been resorbed, whereas the pores of the PA plugs in the defect at the level of the cortex were filled with increasing amounts of new bone. From this moment on bone formation apparently proceeded according to Wolff's law of bone architecture: It depended on the direction and the amount of stress induced in the bone (121-125). 
From the data of this study, the most suitable material to use for treatment of bone defects appeared to be PA70/30 without the addition of allogenic bone marrow. The incubation of PA with allogenic bone/bone marrow, which induced bone formation when implanted subcutaneously in syngeneic Fisher rats (116), did not enhance bone formation when implanted in bone defects. In contrast to non-pretreated Polyactive, an inflammatory reaction occurred. This inflammation, which has to be caused by the allogenic bone marrow, only delayed the formation of new bone tissue; bone formation was not prevented. So, bone formation guided by Polyactive was even present in an inflamed area. Further studies are needed to establish the suitability of Polyactive implanted in inflamed environments.

Pretreatment of Polyactive with bone marrow was also suspected to result in some precalcification of the material, which was expected to be advantageous for the kinetics of new bone formation. Probably due to the inflammatory reaction, this was not the case. In a later study, it was established that precalcification of Polyactive by subsequent incubations with calcium and phosphate significantly enhanced the amount of new bone formed within the first 4 weeks after implantation (126).

A major advantage of PA over a number of ceramic materials is that the material is very easy to handle in the operating theatre and, in most instances, does not need additional fixation. Furthermore, Polyactive does not produce wear particles and can be used in or near a joint surface. Ceramic materials, like hydroxyapatite or tricalcium phosphate, produce wear particles and when used in or near a joint surface additional care has to be taken to avoid wear of the material.

Polymers like Polyactive do not provide immediate mechanical stability. However, it is assumed that mechanical stability is reached within 8 weeks, in case of PA70/30 or PA60/40. Further biomechanical studies are necessary to test the suitability of PA in different anatomical locations. In conclusion it can be stated that PA is a biocompatible, bone-bonding material, suitable to fill cortical bone defects in a stable environment, like screw holes, bone cysts or benign tumours. The behaviour of this material in a less stable environment is subject of another study. Biomechanical studies will be needed to assess the strength of PA implants filled with bone. 


\section{CHAPTER 8}

Quantitative histological analysis of bony ingrowth within the biomaterial Polyactive ${ }^{\mathrm{TM}}$ implanted in different bone locations: an experimental study in rabbits

S.J.M. Bouwmeester, R. Kuijer, M.M.W.E. Sollie- Drees, A.J. van der Linden, S.K. Bulstra

Journal of Materials Science: Materials in Medicine, 9:181-185, 1998 


\section{SUMMARY}

The quantity of bone formed in cylinders of a newly developed erodible copolymer, Polyactive $^{\mathrm{TM}}$ (PA60/40) was examined. PA60/40 was implanted in three different bone locations in the rabbit: in the cortex, in bone marrow and in trabecular subchondral bone. Bony ingrowth was assessed after 4, 8, 26 and 52 weeks after the operation and investigated by histology and image analysis. The ingrowth of bone was observed in PA60/40 placed in the cortex from 4 weeks onwards. After 8 weeks, more than $90 \%$ of the pores of the biomaterial were filled with dense bone. In bone marrow, initially some bone formation was seen. After 26 weeks, all newly formed bone was resorbed. Subchondral bone formation was less than in the cortex of the femur, but somewhat comparable to the amount of bone found in healthy trabecular bone. Bone formation appeared not to be affected by the degradation of the biomaterial. It was concluded that Polyactive ${ }^{\mathrm{TM}}$ is a suitable bone graft substitute. Bone formation within PA60/40 is site-dependent and this follows Wolff's law. 


\section{INTRODUCTION}

Autogenous bone grafts are widely used in orthopaedic practice. These grafts are needed to fill bone defects, to induce an arthrodesis or to heal a pseudarthrosis. The quantity of these grafts, however, is limited. Allogenous bone grafts are often used to overcome this problem. Disadvantages of these allografts are the risk of transmitting infections $(36,127)$. Allografts are more prone to infection, fracture and non-union several years after implantation $(116,128)$. Furthermore, the costs of sampling, work up and storage are high.

In order to overcome these limitations, research has been directed towards artificial materials that may be useful as bone substitutes. Such a material should be mechanically stable, bio-erodible, biocompatible and, most of all, osteoconductive or osteoinductive (128-132). A number of ceramic materials are suitable; however, they are difficult to manipulate and, in general, resorption is low $(115,132,133)$.

Recently, a new material was discovered that proved to be biocompatible, bio-erodible and osteoconductive $(51,52,108,109)$. This material, trademarked Polyactive ${ }^{\mathrm{TM}}$ (PA60/40), is a polyetherpolyester segmented block copolymer, composed of a soft segment, polyethylene oxide (PEO), and a hard segment polybutylene terephthalate (PBT). Based on the same compounds, a whole range of polymers with different degradation characteristics can be obtained by varying the PEO/PBT ratio.

The PEO component stands for the bone-bonding properties of the material, provided it is used in relatively high amounts: $60 \%$ PEO or higher. With increasing amounts of $\mathrm{PEO}$, the degradation is faster $(51,108,120)$. Polyactive ${ }^{\mathrm{TM}}$ was originally used as a synthetic tympanic membrane.

PA60/40 functions as a hydrogel and selectively absorbs calcium from the vicinity (51). PA60/40 has a spongy appearance and it is easy to manipulate. $(51,52,110)$ In other studies PA60/40 proved to be biocompatible and osteoconductive $(52,108-110)$.

In this study Polyactive ${ }^{\mathrm{TM}} 60 / 40$ was used to fill the defects in trabecular bone and the cortex of rabbit femora. The amount of bone growth in the material at the two different locations as well as in the bone marrow was measured semi-quantitatively. 


\section{MATERIALS AND METHODS}

Polyactive $^{\mathrm{TM}}$ 60/40 (PA60/40) cylinders were manufactured and supplied by HC Implants bv., Leiden, The Netherlands. The average pore diameter was $300 \pm 150 \mu \mathrm{m}$; the diameter of the interconnecting pores was $100 \pm 50 \mu \mathrm{m}$. These diameters have been shown to be optimal for the ingrowth of bone $(51,117,118)$.

The cylinders were $4 \mathrm{~mm}$ in diameter and had a length of $5 \mathrm{~mm}$. All PA60/40 cylinders were sterilized by gamma irradiation ( $25 \mathrm{kGy})$ at Gammamaster, Ede, The Netherlands (Fig. 1).

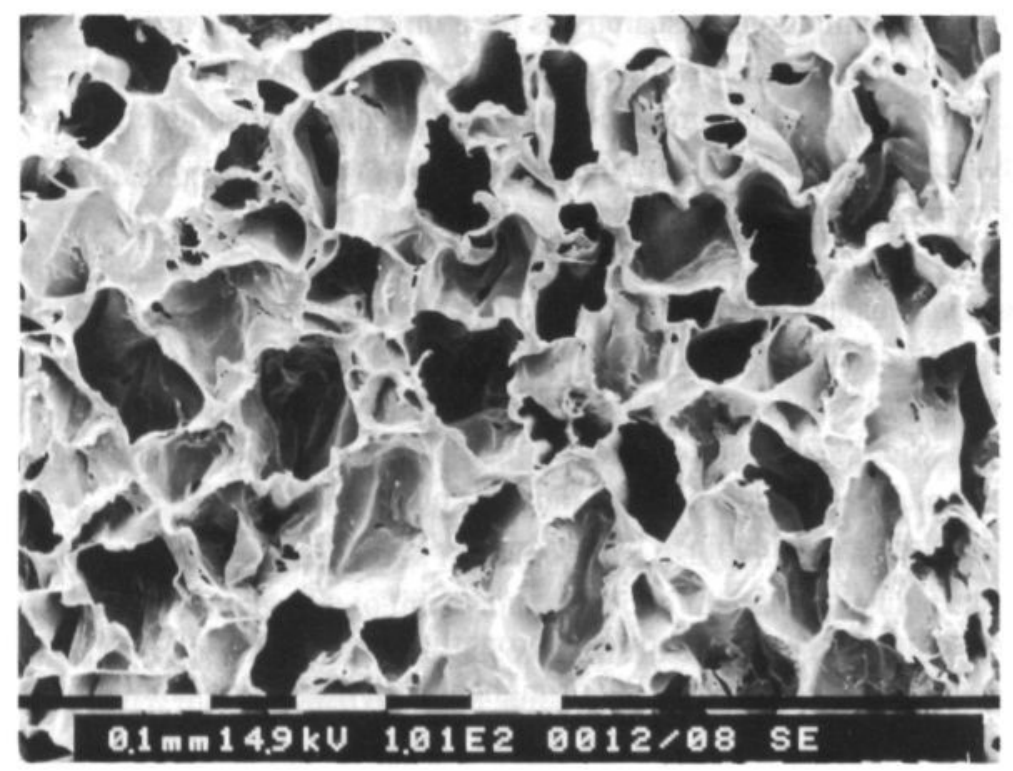

Figure 1. Scanning electron microscopy of surface of Polyactive ${ }^{\mathrm{TM}}$ (Bar $\left.0.1 \mathrm{~mm}\right)$.

The experiments were approved by the local committee for animal experiments. Female New Zealand White Rabbits (32) about 6 months old, were used, weighing between 3.5 and $4.5 \mathrm{~kg}$. The rabbits were anaesthetized using ketamine hydrochloride $\left(100 \mathrm{mg} \mathrm{kg}^{-1}\right)$ and diazepam $\left(8 \mathrm{mg} \mathrm{kg}^{-1}\right)$. The rabbits were in a supine position.

\section{Trabecular bone}

The left knee was opened through a medial parapatellar incision and the patella was dislocated laterally. A borehole of $4 \mathrm{~mm}$ diameter was made in the facies patellaris of 
the femur. A PA60/40 cylinder was placed in the borehole. In the right knee, a sham operation was performed without drilling the borehole.

\section{Cortex}

The right femur was exposed laterally by pushing off the musculature ventrally. The periosteum was moved aside and approximately $1.5 \mathrm{~cm}$ below the major trochanter, a borehole of $4 \mathrm{~mm}$ diameter was made. The PA60/40 cylinder was placed here. Again, the contralateral site was used as a control; a borehole was made without placing a PA60/40 cylinder.

\section{Marrow}

The cylinders were placed in the defect of the femur onto the contralateral cortex. Thus information could be obtained both from the growth of bone within the PA60/40 in the marrow and in the cortex.

Four groups of eight rabbits were sacrificed after respectively 4, 8, 26 and 52 weeks. The animals were killed using an intravenous overdose of thiopental. Both knees and femurs were dissected and fixed in $4 \%$ phosphate-buffered formaldehyde. The specimens were dehydrated through a series of acetone/alcohol solutions and embedded in methylmetacrylate. Sections of $10 \mu \mathrm{m}$ were cut using an innerlock diamond saw and stained with methylene blue and basic fuchsine (119).

To determine the percentage of area occupied by implant material, exudate cells, fibrous tissue and bone, we used an image analyser (Quantimet $570 \mathrm{C}$, Leica Cambridge Ltd, Cambridge, UK). For statistical analysis, data were compared using the one-way ANOVA test.

\section{RESULTS}

From 32 rabbits that were operated on, three died or had to be killed before the end of the experiment. Causes of death were a meningitis in one case and fractures at the level of the borehole in two cases.

\section{Trabecular bone}

Already 4 weeks after implantation, some bone formation was seen in the PA60/40 cylinders placed in the trochlea (Table I). Here, $14.3 \%$ of the total pore area was filled with bone. Besides bone formation, a fibrous cell-dense tissue and bone marrow were seen. At the periphery, trabecular bone and normal bone marrow made contact with 
the PA cylinder and from there on bone growth proceeded. Some bone formation also took place in the center of the cylinder.

After eight weeks, $12.5 \%$ of the pores were filled with bone (Table I, Figs 2 and 3).

After 26 weeks, significantly more bone was seen; both at the periphery and in the center of the cylinder $(28.2 \%, p<0.039)$. The amount of fibrous tissue had diminished.

At 52 weeks the extent of bone formation had diminished to $14.5 \%$.

\section{Table I.}

Percentage of bone in pores of Polyactive ${ }^{\mathrm{TM}}$ in the cortex, the trabecular bone and the marrow at different implantation times

\begin{tabular}{lllllllll}
\hline $\begin{array}{l}\text { Implantation } \\
\text { time (wk) }\end{array}$ & \multicolumn{8}{l}{ Percentage of pores filled with bone } \\
\hline 4 & Cortex & S.D. & S $^{\mathrm{b}}$ & Trab $^{\mathrm{c}}$ & S.D. & $\mathrm{S}^{\mathrm{b}}$ & Marrow & S $^{\mathrm{b}}$ \\
\hline 8 & 39.5 & 31.5 & $*$ & 14.3 & 11.4 & - & 10.4 & ${ }^{*}$ \\
26 & 90.7 & 14.0 & - & 12.5 & 6.5 & - & 2.6 & - \\
52 & 87.6 & 20.6 & - & 28.2 & 4.3 & $\#$ & 0.2 & - \\
\hline
\end{tabular}

'S.D. = standard deviation; ${ }^{b} \mathrm{~S}=$ significance; ${ }^{\mathrm{c}}$ trab = trabecular bone;

$* p<0.001 ; \# p<0.039$.

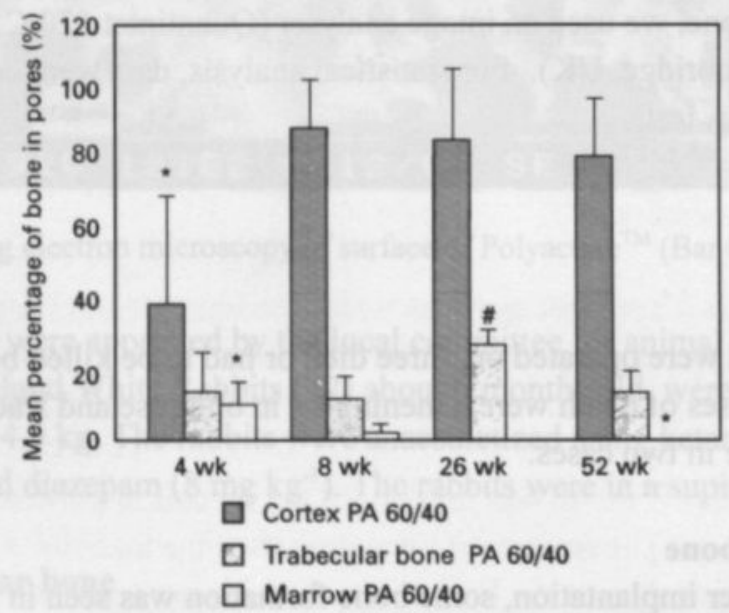

Figure 2. Graph showing the mean percentages of the pores in Polyactive $60 / 40$ filled with bone at different implantation times; ${ }^{*} p<0.001, \# p<0.039$. 


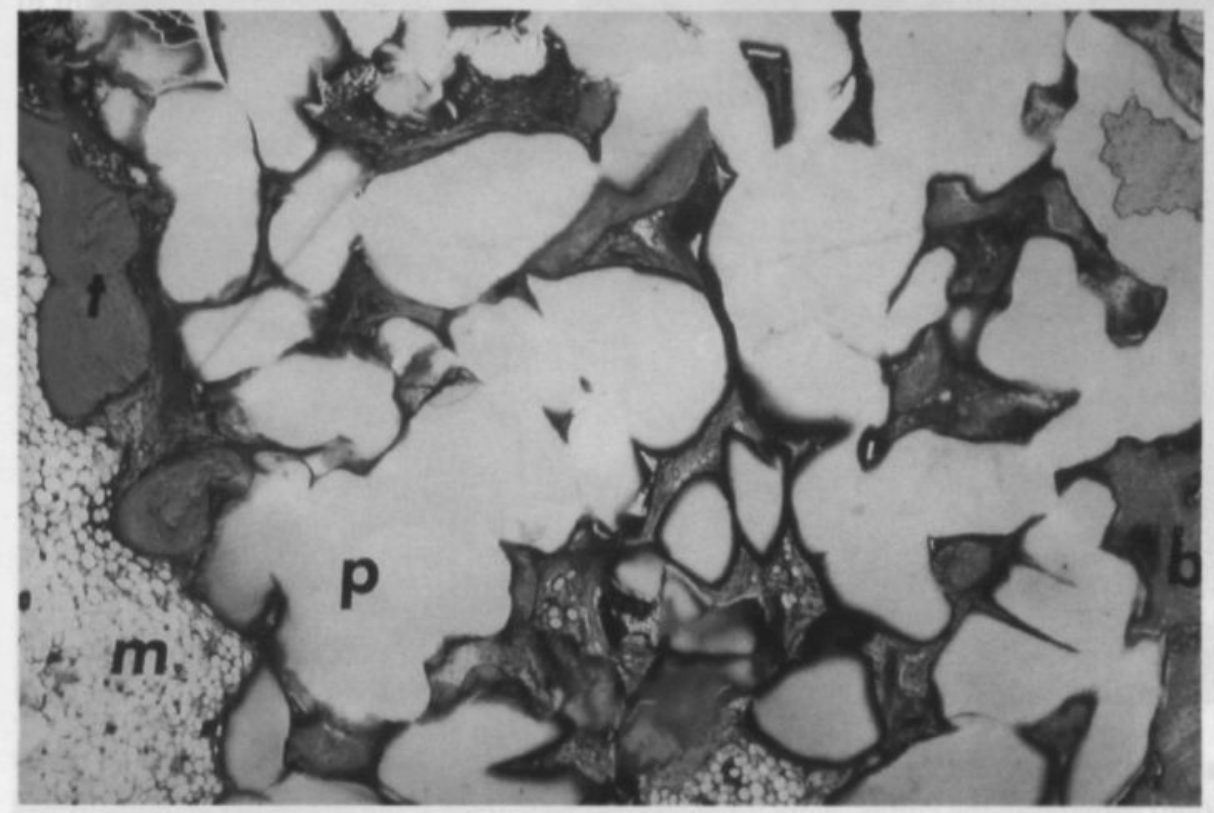

Figure 3. Light micrograph of a section from a sample 8 weeks after implantation of a PA60/40 cylinder in the trabecular bone. $p=$ Polyactive $60 / 40 ; b=$ newly synthesized bone; $\mathrm{m}=$ marrow; $\mathrm{t}=$ trabecular bone $(10 \mu \mathrm{m}$; methylene blue and basic fuchsine; $\mathrm{x} 25)$.

\section{Cortex}

In the cortical level of the femur, the pores of the PA60/40 were mainly filled with a cell-dense fibrous tissue at 4 weeks. Here also, bone formation started from the margins of the cylinder and progressed inwards. At 4 weeks, signifantly less bone was detected in the center of the PA60/40 cylinder compared to 8, 26 and 52 weeks (Table I, Fig. $2, p<0.001$ ). After 8 weeks, $90.7 \%$ of the pores of the PA60/40 cylinder was filled with newly synthesized calcified bone (Fig. 4). After 26 and 52 weeks, respectively, $87.6 \%$ and $83.1 \%$ of the PA60/40 pores were filled with bone (Table I). The remaining part of the pores was filled with fibrous connective tissue and bone marrow.

The control side in the cortex showed marginal bone formation. After 4 or 8 weeks, the defects were still visible and only a relatively thin neocortex was present at the defect site (Fig. 5). After 26 and 52 weeks, in most rabbits the amount of bone matched the control defects. 


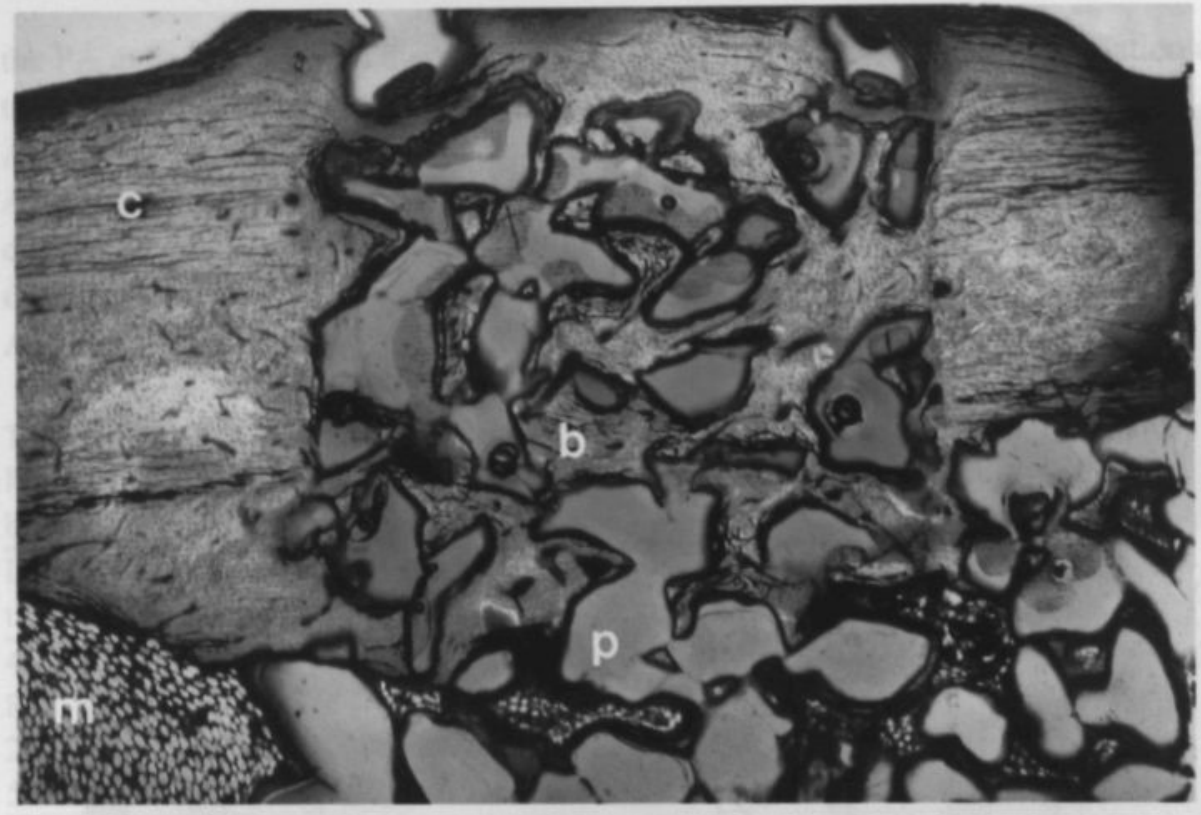

Figure 4. Light micrograph of a section from a sample 8 weeks after implantation of a PA60/40 cylinder in the cortex. Note the thickened neocortex at the site of the cylinder. $\mathrm{p}=$ Polyactive $60 / 40 ; b=$ newly synthesized bone; $c=$ cortex; $m=$ marrow cavity $(10 \mu \mathrm{m}$; methylene blue and basic fuchsine; $x 25$ ).

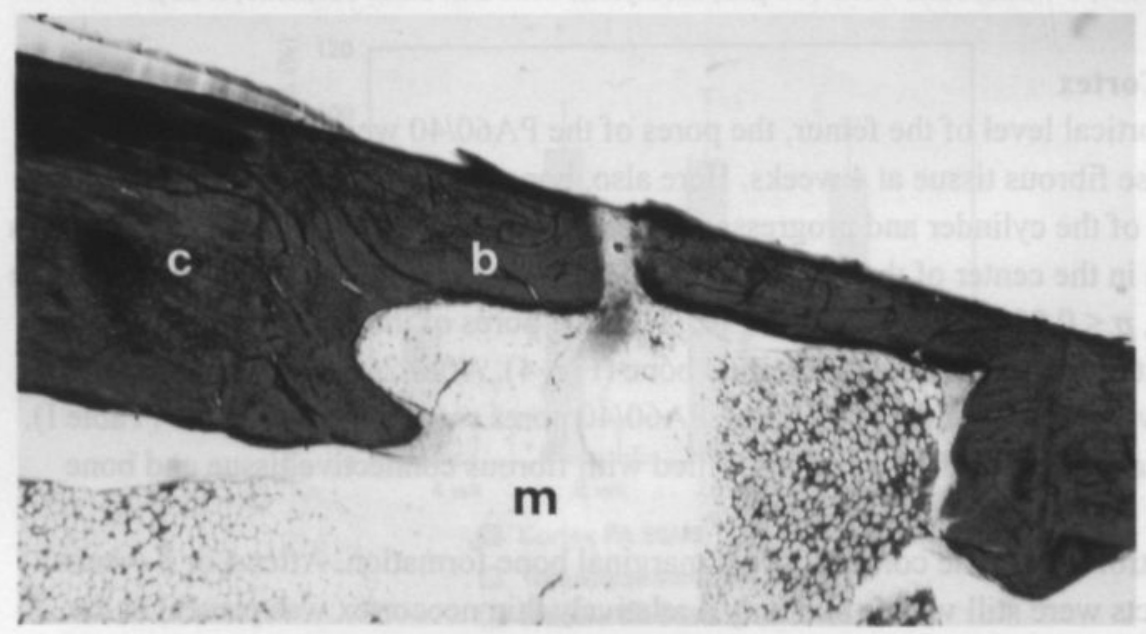

Figure 5. Light micrograph of a section from a sample 8 weeks after making the control defect. Note the relatively thin neocortex. $\mathrm{b}=$ newly synthesized bone; $\mathrm{c}=$ cortex; $\mathrm{m}=$ marrow cavity $(10 \mu \mathrm{m}$; methylene blue and basic fuchsine; $x 25)$. 


\section{Marrow}

In the marrow, the PA60/40 cylinders were predominantly filled with bone marrow cells and some connective tissue. At 4 weeks, $10.4 \%$ of the pores was filled with bone. At later stages, this percentage decreased significantly to $2.6 \%$ (Fig. 6) and below $1 \%$ after, respectively 8 and 26 weeks $(p<0.001)$.

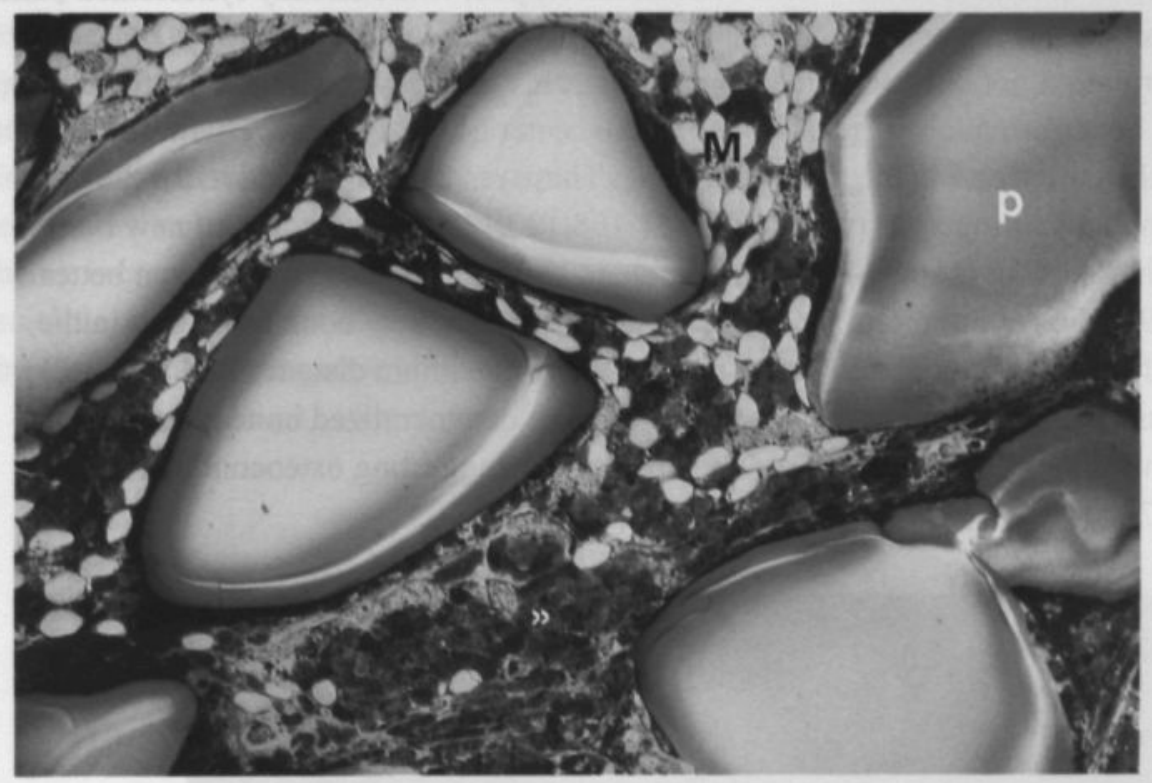

Figure 6. Light micrograph of a section from a sample 4 weeks after implantation of a PA60/40 cylinder in the marrow. $\mathrm{m}=$ marrow cavity; $\mathrm{p}=$ Polyactive $^{\mathrm{TM}} 60 / 40$; 〉 = macrophages filled with Polyactive 60/40 (10 $\mu \mathrm{m}$; methylene blue and basic fuchsine; $\mathrm{x}$ $100)$.

\section{DISCUSSION}

Polyactive $^{\mathrm{TM}} 60 / 40$ was tested as a bone graft substitute in a rabbit model. Image analysis of histological sections was performed on samples yielded at 4, 8, 26 and 52 weeks after the implantation of PA60/40. The results suggest that bone formation in the presence of PA60/40 followed Wolff's law of bone architecture: the structure in bone is the result of a dynamic regulatory process, controlled by mechanical loads. Bone formation occurs depending on the direction and the amount of stress induced in the bone (121-125). Osteocytes, located within the bone, sense mechanical signals and 
these cells mediate osteoclasts and osteoblasts in their vicinity to adapt bone mass (134).

At the cortex, within 8 weeks, $>90 \%$ of the pores of PA60/40 was filled with bone. When PA60/40 was implanted in the cortex of the femur or within the bone marrow, the data were respectively, $12.5 \%$ and $2.6 \%$. After initial calcification and slight bone formation in the marrow, new bone formation stopped, while already synthesized bone was resorbed and replaced by normal bone marrow.

Bone formation not only occurred from the margins of the cylinder towards the center, but new bone formation was also found in the center of the cylinder. This was found both in the cortex and in the trabecular bone. These results are indicative for the osteoconductive properties of PA60/40 $(51,108,120,135)$. The amount of new bone formed in PA60/40 is somewhat comparable to hydroxylapatite (HA) or even better $(128,129,131)$. An important difference is the absence of new bone formation in the center of HA, where bone formation occurs over a maximum distance of $2 \mathrm{~mm}$. Like in porous $\mathrm{HA}$, other bone graft substitutes, such as demineralized bone matrix or coral, only show a peripheral creeping substitution, suggesting osteoconduction $(136,137)$.

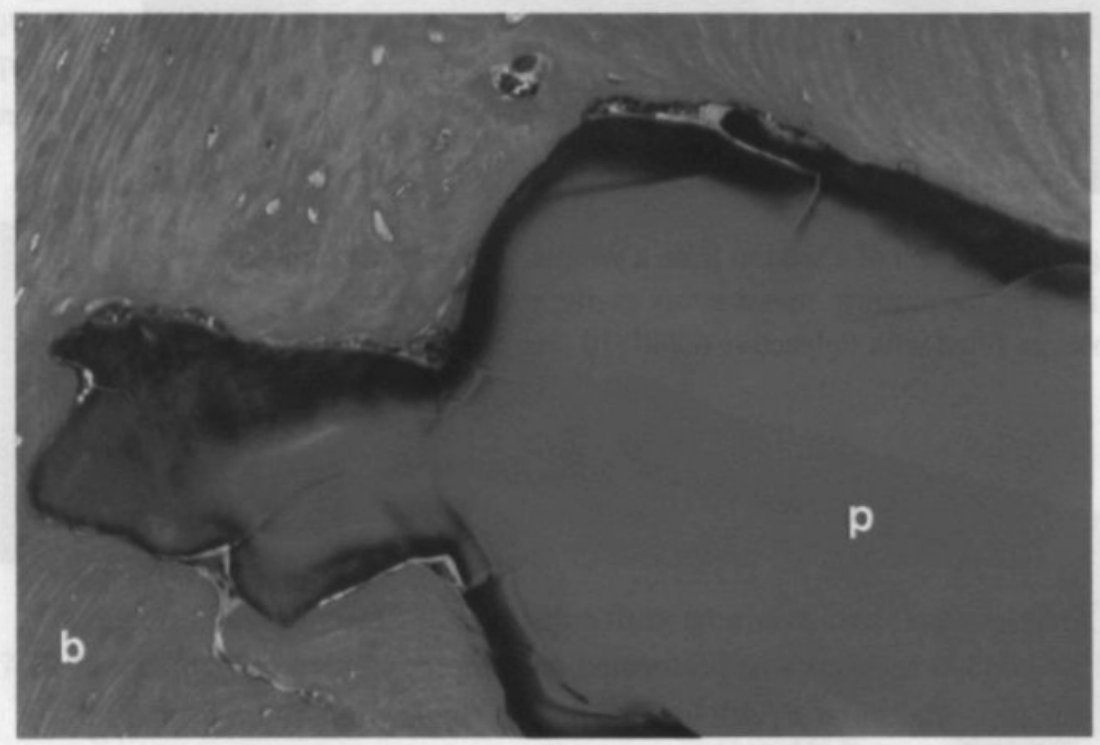

Figure 7. Light micrograph of a section from a sample 8 weeks after implantation of a PA60/40 cylinder in the cortex. Note the close contact between the bone and PA60/40. $\mathrm{p}=$ Polyactive $60 / 40 ; \mathrm{b}=$ newly synthesized bone $(10 \mu \mathrm{m}$; methylene blue and basic fuchsine; $x$ 200). 
Bone formation in PA60/40 was in direct contact with the biomaterial (Fig. 7) as in contrast to apatite- and wollastonite-containing glass-ceramic. In the latter, the radiolucent line, as seen on X-ray examination, only tended to decrease with time (138).

HA provides, in some respects, for immediate mechanical stability, whereas PA60/40 is expected to give the necessary mechanical stability within 8 weeks. Of course, the actual and relative size of the defect are important, and mechanical studies are needed to establish these. In comparison with HA which is brittle and breaks easily, PA60/40 is very easy to manipulate in the operating room. Biomechanical studies are needed to compare the mechanical properties of these biomaterials and other ceramics after being incorporated by bone. In conclusion it can be stated that Polyactive ${ }^{\mathrm{TM}}$ is a suitable substitute for allografts. It is bio-erodible, fully biocompatible and moreover, bioactive, stimulating new bone formation without the need of additives. 


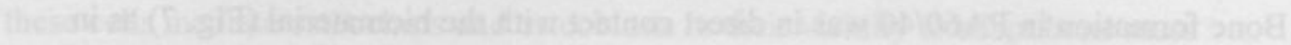

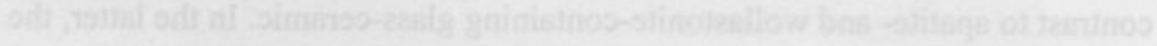

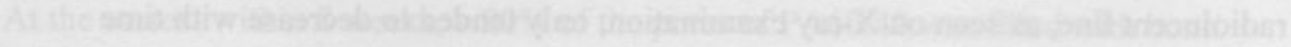

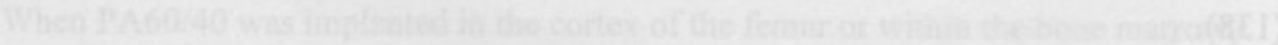

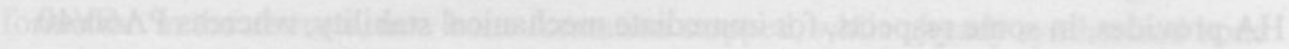

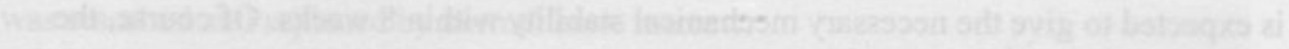

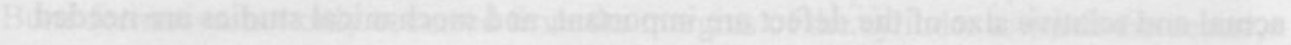

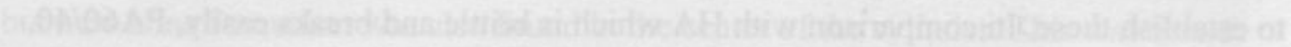

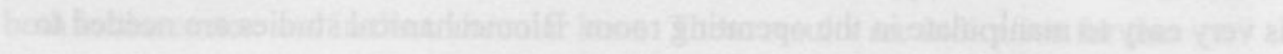

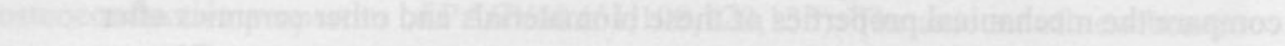

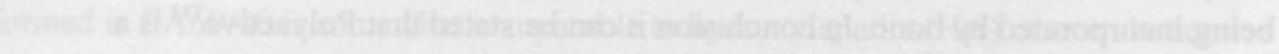

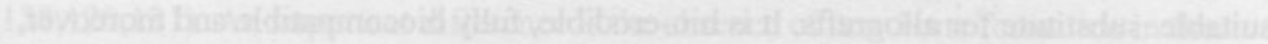

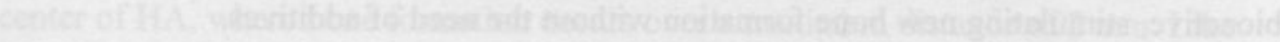

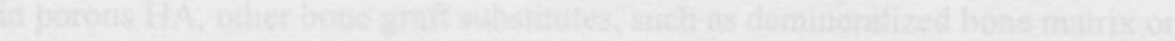




\section{CHAPTER 9}

\section{Histological and biochemical evaluation of perichondrial transplants in human articular cartilage defects}

S.J.M. Bouwmeester, R. Kuijer, E.A.W. Terwindt-Rouwenhorst, A.J. van der Linden, S.K. Bulstra

Revised version under second editorial review of The Journal of Orthopaedic Research 


\section{SUMMARY}

From 1986 to 1992,88 patients with articular defects in the knee were treated with a perichondrial arthroplasty. In this study we report on the results of 22 biopsies of grafted tissue with a mean follow-up of 21 months. Biopsies were obtained at routine arthroscopy after approximately one year, or at arthroscopy or arthotomy at a later stage, when patients were re-operated because of recurrent complaints. Biopsies were only taken when a partial failure was present, or a clear failure resulting in fibrocartilage, a loose flap or a loose body. Biopsies were analyzed histologically, biochemically for the amount of type II collagen, and immuno-histochemically using antibodies for type I, type II, and type X collagen. The well-being of the patients was investigated using the H.S.S. knee score.

The biopsies from 11 patients contained hyaline cartilage with good organization. In the biopsies classified as good during arthroscopy, the mean relative value of collagen type II was $56 \%$. At arthroscopy the grafted area revealed 'macroscopically normal' cartilage in $8 / 22$.

Histological and biochemical analysis of biopsies from failed transplants showed fibrocartilage with mainly type I collagen. These tissues were primarily retrieved from patients with additional abnormalities in their knee joint. It is concluded that adult human perichondrium is able to form hyaline-like cartilage in an isolated cartilage defect in an otherwise healthy knee. 


\section{INTRODUCTION}

Full thickness defects of hyaline articular cartilage have a poor capacity to repair. Spontaneous regeneration of traumatic and osteoarthritic (OA) cartilage defects results in the formation of fibrocartilage $(9,139,140,141)$. Shaving or drilling of a cartilage defect also results in the formation of fibrocartilage, although it has been reported that small defects may heal towards hyaline cartilage $(9,12,142)$. Biomechanically, fibrocartilage is inferior to normal hyaline cartilage and therefore may only provide for a temporary less symptomatic joint.

The possibility to restore cartilage defects with autologous or homologous tissue capable to form hyaline cartilage has been studied extensively $(43,47,48,63,75,94,95,143,144)$. These in vivo and in vitro studies showed that animal and adult human perichondrium were capable to form hyaline cartilage. The transplantation of rib perichondrium to restore cartilage defects in the human knee was introduced (45). Autologous rib perichondrium was transplanted to cartilage defects in the knee using fibrin glue (Tissucol ${ }^{8}$ ) as an adhesive (145). One year after the operation the transplantation had reduced the complaints of many patients significantly (46). However, not every defect appeared to be repaired with hyaline cartilage.

In this study we investigated the biological status of perichondrial transplants and correlated these data with the preoperative clinical diagnosis of the patients. At arthroscopy approximately one year after the operation, we examined whether the transplant was firmly attached to the subchondral bone. Whenever ethically allowed, a biopsy was taken and studied by histological and immunohistochemical methods. Biochemically the percentage of collagen type II present in the biopsy was assessed. The correlations between clinical, arthroscopical and histological results were examined.

\section{METHODS}

Perichondrial arthroplasty was performed in 88 patients with articular defects in the knee. Patients with osteoarthritis or previous operations such as drilling procedures to induce cartilage repair of the knee were also included (45). For this study approval of the Institutional Review Board was obtained. 


\section{Perichondrium transplantation and post-operative treatment}

During the first operation, the perichondrial transplantation, the chondral lesion was identified and sharply cleaned until point-bleeding of the subchondral bone was visible. The size of the defect was measured. Then the perichondrium was removed from the anterior side at the cartilaginous part of one of the lower ribs at the conjoint part near the sternum. Perichondrium was placed into the cartilage defect with its chondrogenic side up (cambium layer up). The graft was fixed with fibrin glue (Tissucol $^{\circledR}$, Immuno, Vienna, Austria) to the subchondral bone. After an immobilization period of two weeks in a plaster, the operated knee was subjected to continuous passive motion (CPM) for 6-8 hours a day until $90^{\circ}$ of flexion was reached (mean time: one week) (89). The patients were then allowed to walk nonweight bearing. Partial weight bearing was allowed 6 weeks after the operation and continued until 12 weeks after the operation (45).

\section{Biopsies}

After approximately one year a routine arthroscopy was performed on all patients. No patients were lost to arthroscopic follow-up. In this study we report the results of 22 biopsies of cartilaginous tissue in 22 patients (22/88) (Table I). Of these biopsies 8 were obtained at routine arthroscopy, and 14 at an arthroscopy or arthrotomy at an earlier or later stage, performed because of recurrent complaints. The mean follow-up at the time of the biopsy was 21 months (median 17).

\section{Table I.}

Macroscopical results of biopsies of perichondrial grafts; distribution over two different patient groups

\begin{tabular}{lll}
\hline & Group $\mathrm{A}^{1}$ & Group $\mathrm{B}^{2}$ \\
\cline { 2 - 3 } & $n=14$ & $n=8$ \\
\hline Loose body/fibrous cartilage & 1 & 7 \\
Hyaline cartilage & 13 & 1 \\
\hline
\end{tabular}

A: patients with an isolated defect, no concommitant osteoarthritis.

${ }^{2} \mathrm{~B}$ : patients with concommitant osteoarthritis/anomalities.

At routine arthroscopy, biopsies were only taken in case of a loose flap of cartilage, a loose body or a failure resulting in fibrocartilage. Biopsies were taken from the center of the graft or at the rim in case of a loose flap. When core biopsies were taken, the diameter of the biopsies was $3 \mathrm{~mm}$ and the depth approximately $1 \mathrm{~cm}$. Smooth, apparently normal cartilage was left undisturbed. If only a color change was seen at 
the margin of the transplant without any signs of loosening or changes in consistency, no biopsy was taken and the result was classified as excellent.

\section{Arthroscopy and clinical data}

The quality of the cartilage at the transplant site and in the other parts of the knee was assessed. Cartilage that looked normal and felt 'healthy' when compressed upon with an arthroscopic hook, was distinguished from fibrocartilage, which was defined as clearly softened cartilage with an irregular and fibrillated surface. The outcome of the arthroscopy was classified 'excellent' if the transplant could not be distinguished from the surrounding cartilage. A slight irregularity of the transplant with good fixation and consistency was classified as 'good'. A slight irregularity of the transplant combined with loosening and a graft feeling relatively too hard or too soft was classified 'fair'. 'Poor' results were grossly irregular or elevated grafts, large loose rims or bare areas. The clinical results were scored using the Hospital for Special Surgery Knee Score (H.S.S.S.). A result was rated as 'excellent/good' if the H.S.S.S. was $>85$, 'fair' if 75-84 and 'poor' if $<75$. Standard X-rays were obtained just prior to arthroscopy or arthrotomy.

\section{Histology and immunohistochemistry}

For the histological evaluation a part of a biopsy was fixed in cold $4 \%$ buffered formaldehyde ( $=10 \%$ formalin) for 24 hours, a second part was frozen in Tissue-Tek. Half of the samples were subsequently demineralized in $10 \%$ EDTA, dehydrated with ethanol, transferred to Histosol (National Diagnostics, Sommerville, NY, USA) and embedded in paraffin. The second half was not demineralized, and was embedded in glycolmethacrylate (GMA) (Technovit 7100, Kulzer, Wehrheim, Germany). Ten micrometer sections were stained with safranin-O ( $1 \%$ filtered solution, $\mathrm{pH}=6.7$, $\mathrm{BDH}$ chemicals, Germany), erös red, sirius red $(0.1 \%$ Sirius red in picrin acid $\mathrm{pH}=$ $2.0,90 \mathrm{~min}$.) or alcian blue (only the paraffin embedded sections) (47). For the qualitative analysis of the collagen type present in the newly synthesized cartilage layer, histological sections were stained with specific antibodies to collagen types I and II (Southern Biotechnology, Birmingham, USA). Frozen sections were stained with a specific polyclonal antibody to collagen type $\mathrm{X}$ at the laboratory of Prof. Dr. K. von der Mark, Erlangen, Germany) (146).

Microscopically, cartilage was defined as hyaline if the newly formed tissue showed articular cartilage with its typical organization. Staining with alcian-blue revealed an extensively and evenly stained matrix, indicating the presence of high amounts of glycosaminoglycans (GAG). 
Hyaline cartilage and fibrocartilage were distinguished using sirius red staining of the sections and polarization microscopy with monochromatic light. Hyaline cartilage is hardly birefringent, whereas fibrocartilage shows randomly oriented, birefringent collagen fibers (167). Other properties of fibrocartilage were an abnormal organization of the cartilage with safranin-O stained sections and a strong, although not even, staining with alcian-blue.

Sections of grafted tissue were scored as follows: $++=>50 \%$ hyaline cartilage with good organization, $+=<50 \%$ hyaline cartilage with good organization, $\pm=$ fibrous cartilage, $-=0 \%$ cartilage.

\section{Biochemical analysis}

For the quantitative analysis of collagen types 12 biopsies were used and subjected to cyanogen bromide digestion. Cyanogen bromide derived peptides were analyzed with sodiumdodecyl sulfate polyacrylamide gel electrophoresis as described by O'Driscoll et al. (147). Type I Collagen from rat tail tendon (Boehringer Mannheim, Almere, The Netherlands) and type II collagen from human articular cartilage were used as standards (148).

\section{Correlations}

The correlations between clinical, arthroscopical and histological results were examined using the Spearman's rho test.

\section{RESULTS}

The mean follow-up of the time of biopsy after the perichondrial arthroplasty was 21 months (5-61). The mean surface area that was repaired with perichondrium was 2.4 $\mathrm{cm}^{2}$. There were no significant differences in the dimensions of the defects between failed and successful transplants. There were no complications at the donor site.

\section{Macroscopical results}

The attachment of the transplant to the subchondral bone was examined macroscopically. We checked upon any loosening of the transplant or whether the transplant had formed a loose body.

In 14 of the 22 patients a loose flap at the rim of hyaline-like repair cartilage was taken as a biopsy. These biopsies were part of full depth cartilaginous tissue. In a few cases, fibrillated pieces of poor quality were removed. 
Detached transplants seen as loose bodies were found in 4 patients, leaving a clear defect in the cartilage unto the subchondral bone or a defect filled with fibrocartilage or fibrous tissue at the original transplantation site.

In 4 other patients biopsies were obtained from the transplantation sites that were filled with fibrocartilage. Radiologically diffuse calcification of the transplant was seen in these 4 patients between 6 and 12 months after the perichondrium transplantation (153). The 8 biopsies showing fibrocartilage or complete loosening of the graft were merely obtained from patients who had additional anomalies in the knee at the time of the primary operation, such as meniscal tears, instability or degenerative changes (Table I).

\section{Microscopical results}

Overall, histological analysis of the newly formed tissue showed cartilage with hyaline aspects as seen in normal articular cartilage with flattened cells in the superficial layer and more rounded cells in the intermediate and deep zones (Fig. 1).

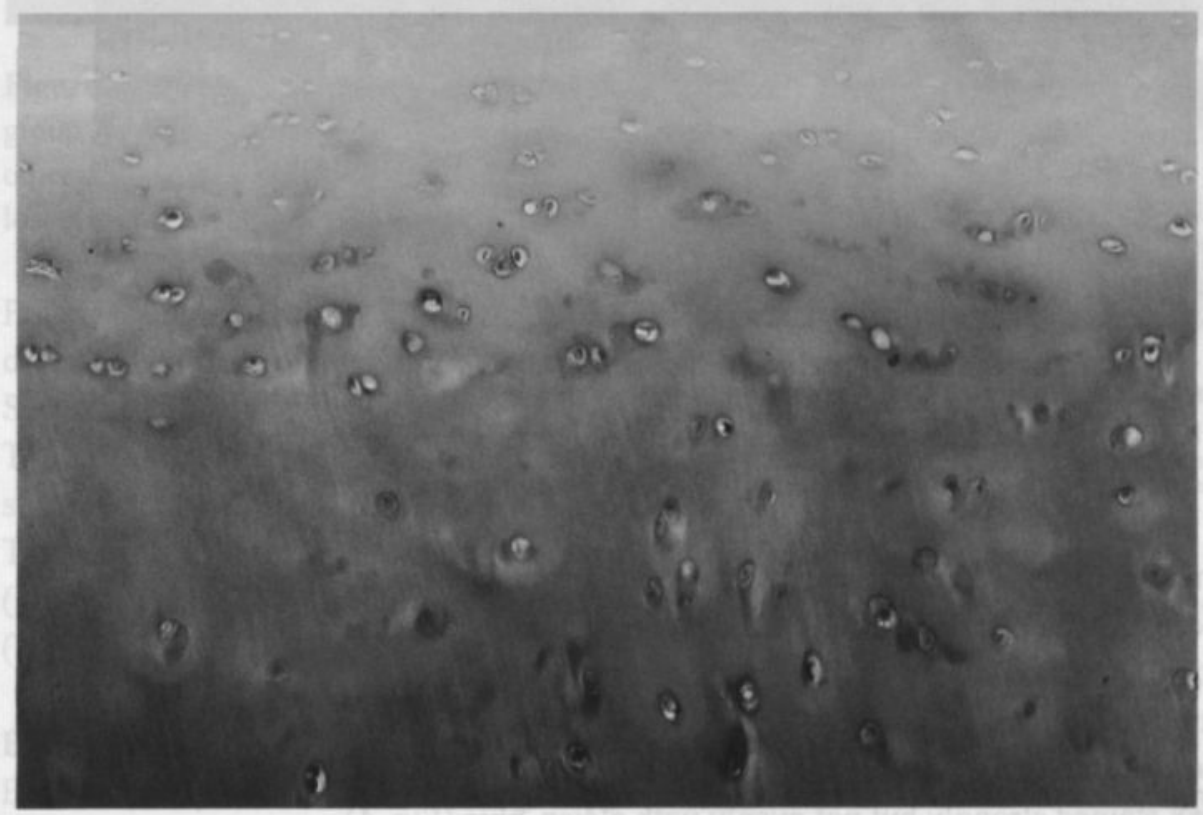

Figure 1. Light micrograph of a section of biopsy number 3 (Table II) from a patient of group A. Aspect of hyaline-like cartilage. Normal, regular aspect of chondrocytes embedded in evenly stained cartilage matrix indicating the presence of high glycosaminoglycans normal for hyaline cartilage $(10 \mu \mathrm{m}$; alcian blue; x 20$)$. 
More or less hyaline-like cartilage was seen in 11/22 biopsies. The matrix stained extensively and evenly with alcian blue. Polarization microscopy showed an homogeneous, hardly polarizing tissue without signs of type I collagen fibers (Fig. 3). These sections did not stain with the calcium dye erös red (data not shown). Immunohistochemical staining revealed the presence of type II collagen, whereas collagen type I and X were not detected.

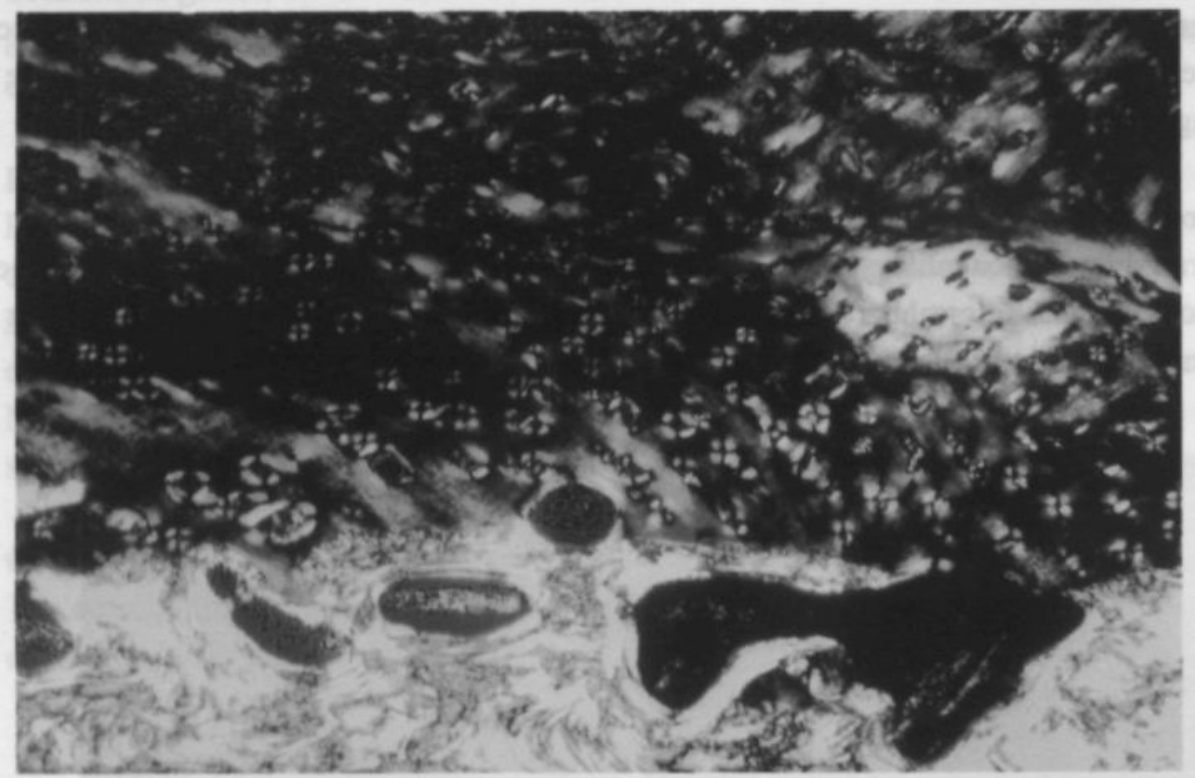

Figure 3. Light micrograph of a section of biopsy number 3 (Table II). See Figure 2. Section of a biopsy of a perichondrial transplant. The well organized tructure of the hyaline cartilage to the subchondral bone can be seen $(10 \mu \mathrm{m}$; sirius red using polarization technique; $\mathrm{x} 10)$.

In the 4 patients where biopsies were obtained from transplantation sites that were filled with softened, fibrillated cartilage, the subchondral bone showed new osteoid apposition. Calcification of the fibrillated tissue was seen using erös red staining. Sections of this tissue stained with $\mathrm{H} / \mathrm{E}$ showed fibrocartilage and fibrous tissue. Zones of fibrous tissue were seen next to regions with hyaline-like cartilage. The matrix stained strongly but not evenly with alcian-blue (Fig. 4). 


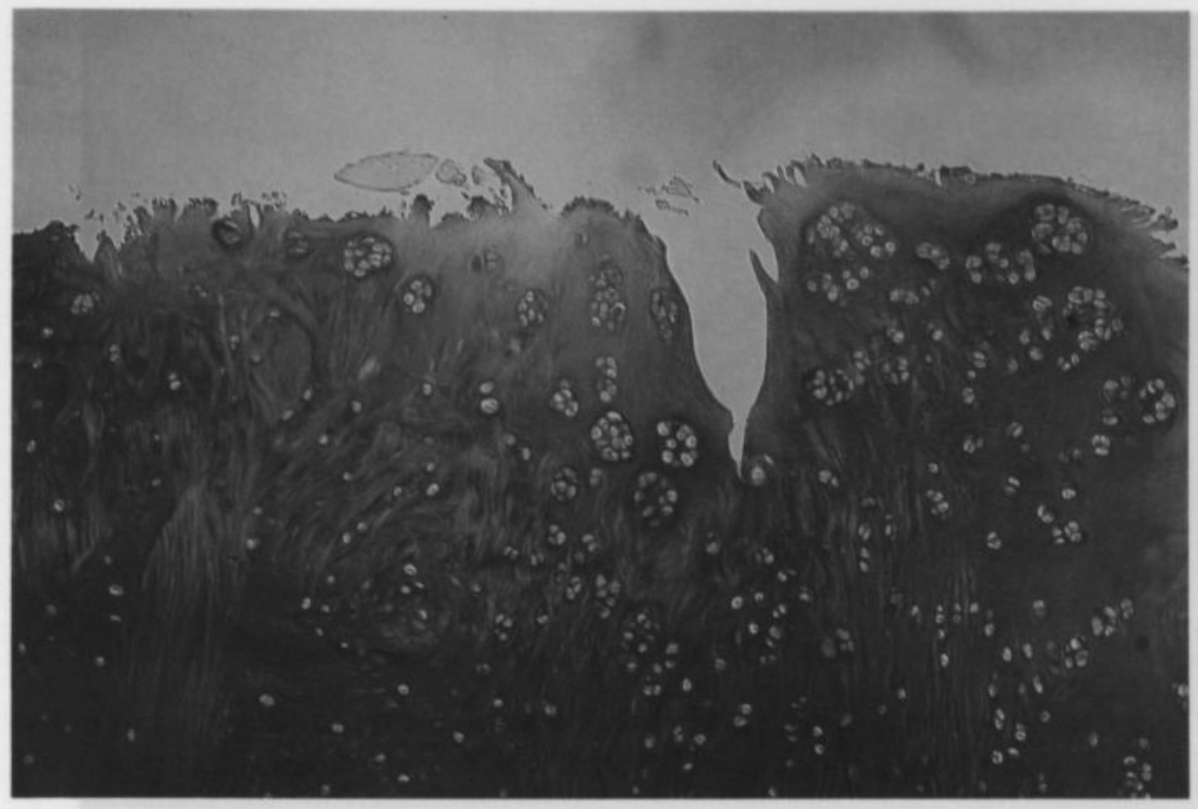

Figure 4. Light micrograph of a section of biopsy number 14 (Table II) from a patient of group A. A large cleft at the surface of the cartilage can be seen next to large cell nests and other degenerative changes. The matrix is not evenly stained and the normal architecture is lost $(10 \mu \mathrm{m}$; alcian blue/PAS; $\times 10)$.

Polarization microscopy of sirius red stained sections showed randomly oriented, diversely stained collagen fibers and confirmed the presence of fibrocartilage.

Sections stained positively with antibodies to type I and type X collagen.

The histological aspect of loose bodies showed a typical area of central ossification surrounded by fibrocartilage (data not shown).

Transplants from patients with isolated cartilage defects and an otherwise healthy knee (group A) showed hyaline-like cartilage with good organization in $6 / 14$ of the cases (Fig. 2).

\section{Biochemical results}

Biochemically, the content of collagen type II varied from 0 to $82 \%$ in the 12 biopsies analyzed (Table II). In the biopsies classified as good during arthroscopy both collagen type I and collagen type II were present. The mean relative value of collagen type II was $56 \%$ (Table II: pat no. $3,5,7,8,9$ ). 


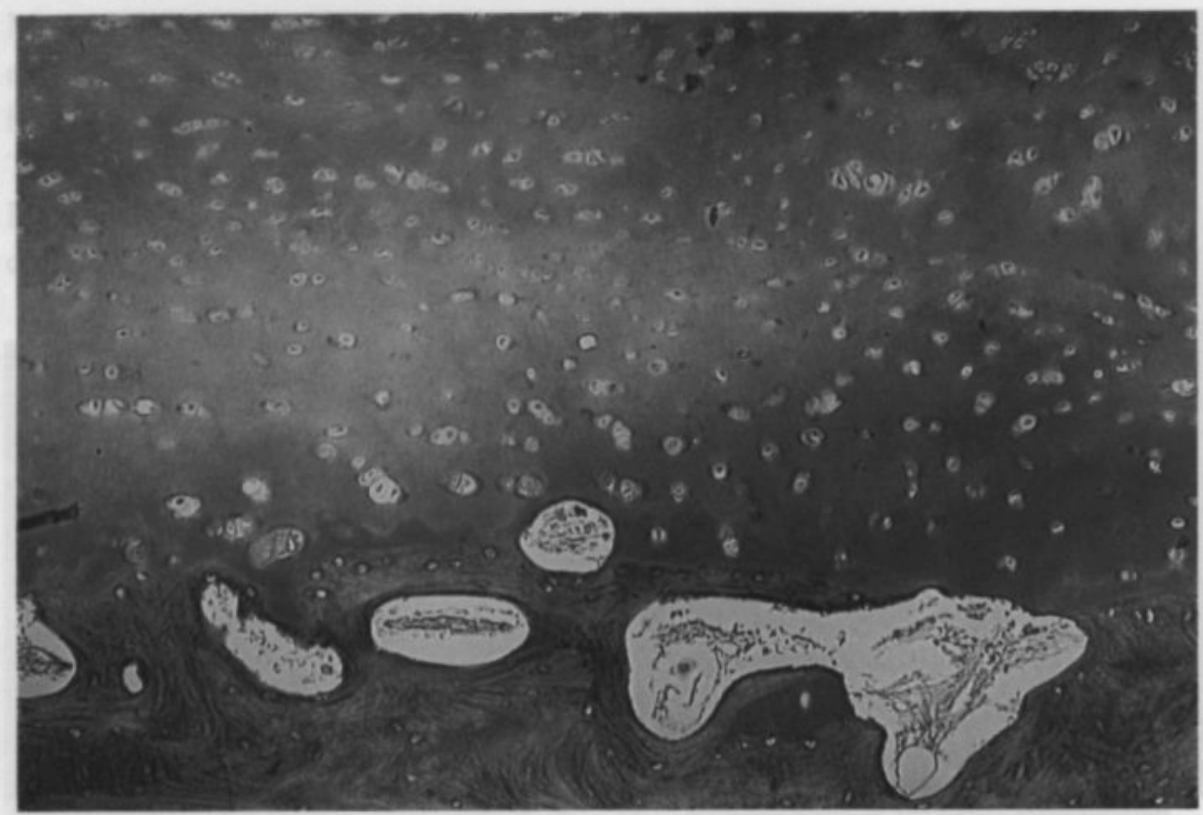

Figure 2. Photomicrograph of a section of biopsy number 3 (Table II) from a patient of group A. Magnification $10 \mathrm{x}$. Staining sirius red. Section of a biopsy of a perichondrial transplant. A good attachment of the cartilage to the subchondral bone can be seen. The matrix and the orientation of the chondrocytes resemble normal hyaline cartilage.

\section{Clinical results}

Using the H.S.S. knee score 5 patients were rated as excellent or good, 2 patients scored fair and 15 patients poor (Table II).

\section{Statistical analysis}

There was a strong correlation between the arthroscopical and clinical results $(p=$ 0.002).

The correlations between histology versus clinic or arthroscopy were not significant.

\section{DISCUSSION}

In this study the potential of perichondrium transplanted into a cartilage defect of the knee to form hyaline cartilage was examined. The 5-year follow-up of the clinical results, resulting in a limitation of the inclusion criteria, were described in a previous 
study (153). Perichondrium was placed with the chondrogenic layer up. Previous unpublished work by Homminga did not show great differences (as confirmed by Salter), but placing the cambium layer up was slightly preferential.

Histological and biochemical studies were done on biopsies from grafts obtained at arthroscopy or arthrotomy at a mean follow-up of 21 months. Size and location of both the defects and the biopsies were not standardized, which may partly account for the variability in the results. Another source of variability is the diversity in clinical diagnosis.

At arthroscopy biopsies were only taken when a loose flap of cartilage, a loose body or a failure with fibrocartilage were present. The histological results seem disappointing but one has to take into account that no biopsies were taken from normal, firmly attached grafted tissue.

Histological and biochemical evaluation of the biopsies confirmed the data of other authors showing that autologous rib perichondrium is able to form hyaline cartilage in the human knee $(45,75,145)$.

Radiological calcification protruding from the subchondral bone plate was seen in the successful cases. This did not influence the histological or arthroscopical aspects of the transplant, neither did it affect the clinical outcome at the respective follow-up.

Histologically, the loose rims of the transplants obtained from successful cases (one year after the operation) consisted mainly of hyaline-like cartilage. Hypertrophy of the chondrocytes or the presence of collagen type $\mathrm{X}$ was not observed in these biopsies at this short term follow-up (150). No calcification was found in these biopsies, suggesting that the calcification as seen radiologically was merely outgrowth of the subchondral bone, resulting from fixation of the subchondral bone to the perichondrial graft. This ossification process may lead to thinning, and at the long-term to degeneration of the regenerated cartilage (156). However, our ten-year follow-up data do not show such a trend (chapter 10).

The relatively high content of collagen type II confirmed the presence of primarily hyaline cartilage.

The loose flaps found in 14 of the 22 patients appear to be derived from failures of attachment, although detachment due to overgrowth and/or incongruency can not be 
excluded. The loosening of the transplants may have been caused by insufficient scratching of the subchondral bone (44). On the other hand, when too much subchondral bone was removed, the restoration of bloodflow might have been the cause for the transplant to loosen. The use of fibrin glue has been subject of much debate, because of the limited adhesive properties. Another biological adhesive, tissue transglutaminase, may be a good alternative, but this will need further investigation $(168,169)$. Also the incongruency in the post-operative period when CPM was applied, may be responsible for the frequently observed loosening of the transplant in these degenerative joints.

In those patients where perichondrial transplantation was performed in a knee with additional degenerative changes of the cartilage, failure of the perichondrium to produce firm healthy cartilage was observed at control arthroscopy. Diffuse calcification throughout the graft was seen radiologically and histologically, although the clinical results at that time were not as bad as arthroscopical and histological results suggested. Our data indicate that hypertrophic differentiation of the cells in the graft might be an explanation for the early calcification of the transplant in an osteoarthritic joint. The presence of type $\mathrm{X}$ collagen is indicative of hypertrophic chondrocytes, which are responsible for the calcification of the matrix. Whether this process is influenced by factors present in the synovial fluid of osteoarthritic joints, as has been suggested by other investigators, remains to be elucidated (150-152). Also, the usual sclerosis of the subchondral bone in an osteoarthritic joint will severely hamper the scratching procedure, which appeared to be critical as is discussed above.

All together, it is concluded that osteoarthritis is a contra-indication for a perichondrium transplantation. After the outcome of this study, the inclusion criteria for this procedure to restore articular cartilage defects were adjusted.

The difference in correlations between histology on one side and clinic and arthroscopy on the other are probably due to the difficulty of obtaining a biopsy in an area without clear macroscopical borders between normal cartilage, cartilage deriving from the perichondrial transplantation or fibrocartilage.

This study suggests that even relatively large isolated cartilage defects can be treated with a perichondrial arthroplasty. When combining the histological, biochemical, arthroscopical and clinical data it is clear that only in patients without degenerative changes in the rest of the knee, healthy hyaline cartilage may be expected. 


\section{Table II.}

List of samples obtained at arthroscopy

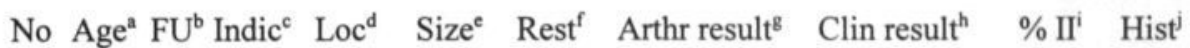

\begin{tabular}{llrllllllll}
\hline 1 & 22 & 19 & UK & PAT & 3 & A & POOR & POOR & 10 & - \\
2 & 30 & 21 & TR & PAT & 1 & A & POOR & POOR & 82 & + \\
3 & 35 & 10 & TR & MFC & 2.3 & A & GOOD & GOOD & 77 & + \\
4 & 27 & 14 & OD & MFC & 2 & A & POOR & POOR & 27 & + \\
5 & 42 & 27 & UK & PAT & 1 & A & GOOD & POOR & 20 & \pm \\
6 & 27 & 14 & OD & MFC & 2 & A & POOR & POOR & 66 & + \\
7 & 22 & 6 & DL & PAT & 1 & A & GOOD & FAIR & 75 & ++ \\
8 & 31 & 34 & OA & PAT & 4.5 & B & GOOD & POOR & 48 & + \\
9 & 33 & 10 & TR & MFC & 3.8 & B & GOOD & EXCELL & 61 & ++ \\
10 & 43 & 5 & UK & MFC & 1.4 & A & GOOD & FAIR & 0 & + \\
11 & 22 & 19 & UK & PAT & 3 & A & POOR & POOR & 0 & - \\
12 & 26 & 10 & UK & PAT & 3 & A & GOOD & GOOD & 0 & - \\
13 & 16 & 14 & UK & PAT & 2.3 & A & POOR & POOR & ND & \pm \\
14 & 17 & 24 & TR & PAT & 3.8 & A & POOR & POOR & ND & \pm \\
15 & 30 & 21 & TR & PAT & 1 & A & POOR & POOR & ND & \pm \\
16 & 27 & 61 & UK & PAT & 3 & A & POOR & POOR & ND & \pm \\
17 & 32 & 13 & OA & TRO & 6 & B & FAIR & GOOD & ND & + \\
18 & 44 & 16 & OA & PAT & 2 & B & POOR & POOR & ND & - \\
19 & 27 & 13 & TR & PAT & 2 & B & FAIR & POOR & ND & - \\
20 & 41 & 43 & TR & MFC & 1.5 & B & POOR & POOR & ND & ++ \\
21 & 15 & 31 & OD & MFC & 2 & B & GOOD & POOR & ND & ++ \\
22 & 38 & 26 & TR & PAT & 0.4 & C & FAIR & GOOD & ND & ND \\
\hline
\end{tabular}

${ }^{a}=$ age patient at time of perichondrium transplantation. ${ }^{b}=$ follow-up in months at time of arthroscopy and collecting the sample. ${ }^{\mathrm{c}}=$ indication for perichondrial arthroplasty; OA, osteoarthritis, OD, osteochondritis dissecans, DL, dislocation, TR, trauma, UK, unknown. ${ }^{d}=$ location of defect; PAT, patella, MFC, medial femoral condyle, TRO, trochlea. ${ }^{e}=$ size of graft in $\mathrm{cm}^{2} .{ }^{\mathrm{f}}=$ quality of cartilage in the rest of the knee; A, normal cartilage, B, Grade 1-2 osteoarthritic changes, C, Grade 3-4 osteoarthritic changes.

$\mathbf{g}=$ arthroscopical result; Excellent: transplant can not be distinguished from surrounding cartilage, Good, slight irregular transplant with good fixation and consistency, Fair: irregular transplant combined with loosening and/or graft feeling relatively too hard or too soft, Poor:

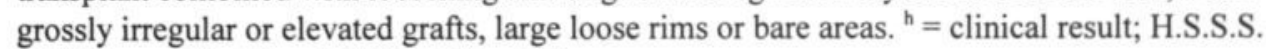
85-100: excellent/good, 75-84: fair, < 75: poor.

$\mathrm{i}=$ percentage Collagen type II, ND, analysis not done $.^{j}=$ histology score $;++:>50 \%$ hyaline cartilage with good organization, $+:<50 \%$ hyaline cartilage with good organization, \pm :

fibrous cartilage, -: $0 \%$ cartilage, $\mathrm{ND}$, biopsy not taken 


\section{CHAPTER 10}

\section{Ten year follow-up of human perichondrial grafting versus debridement of cartilage defects in the knee.}

S.J.M. Bouwmeester, R. Kuijer, G.N. Homminga, S.K. Bulstra, R.G.T. Geesink

Submitted to The Journal of Bone and Joint Surgery, American Volume 


\section{SUMMARY}

From 1986 to 1992,88 patients with articular cartilage defects in the knee were treated with a perichondrial transplantation (PT). In the lesions an autogenous strip of costal perichondrium was fixed with fibrin glue. Fourteen patients met the revised inclusion criteria: age under forty years, no previous drilling or shaving of the defect, no more than one graft at the time of operation and no more than osteoarthritis grade two in other parts of the knee (153). Using the same inclusion criteria, a second group of eleven patients was formed from another prospective study consisting of 150 patients. These patients underwent an arthrotomy and debridement and drilling (DB) of the cartilage defect.

The results of both procedures after ten to eleven years were evaluated with the Hospital for Special Surgery Knee Score (HSSS), X-ray examination, by clinical examination and by Visual Analogue Scale (VAS). Both techniques resulted in a general improvement.

Compared to the situation before the operation, after ten years the PT group showed a slightly larger increase concerning the HSSS difference (PT 18,5 $\leftrightarrow$ DB 17,7). The VAS for walking was slightly worse for the PT group (PT 2,0 $\leftrightarrow$ DB 1,1). In rest the scores were PT $0,9 \leftrightarrow$ DB 0,7 . Both groups showed an equal number of irregular operation surface sites on X-ray (PT 9/11 $\leftrightarrow$ DB 8/10).

This study shows that ten years after treatment, perichondrium transplantation does not perform better than open debridement and drilling. This raises questions about the added value of perichondrium transplantation over open debridement. 


\section{INTRODUCTION}

Articular cartilage defects have a poor capacity to repair. Superficial cartilage defects do not heal at all. Full thickness defects penetrating the subchondral bone heal with a fibrous or fibrocartilagenous tissue, biomechanically inferior to healthy hyaline cartilage $(11,12,17)$. Nevertheless, the current treatment of such defects is focussed on removing diseased tissue and penetrating the subchondral bone to allow filling of the defect with fibrocartilage $(21,154)$. In short this operation is called debridement and drilling.

Many methods to restore articular cartilage have been investigated, with varying results in animal studies and clinical trials (18). These include transplantation of osteochondral shell grafts, autogenous transplantation of perichondrium or periosteum, chondrocytes or mesenchymal stem cells $(29,161,162)$. The use of Holmium:YAG laser is still controversial (163).

A widely used technique to reduce pain and improve joint function is to shave the damaged cartilage and to drill holes into the subchondral bone. There is no evidence that shaving alone stimulates repair (164). The relief is usually temporary unless an additional procedure intended to correct the underlying abnormalities that created the cartilage damage in the first place is added (patellar realignment/ high tibial osteotomy for varus or valgus abnormalities) (15). The resulting fibrocartilagenous tissue may provide for a less symptomatic joint, but also for early onset of osteoarthritis.

Debridement of an incongruent cartilage can decrease the mechanical and inflammatory symptoms of unstable flaps or from fibrillation or other distortion from anatomy. Repair tissue can reduce symptoms but it does not prevent deterioration of the cartilage (18).

Rib perichondrium when transplanted into a cartilage defect produces a repair tissue that resembles hyaline cartilage $(63,64,69,95,99,155,156)$. In an animal model, this newly formed cartilage has been shown to have the same visco-elastic properties as hyaline cartilage (75). Neocartilage with histological and biochemical qualities similar to that of normal articular cartilage has been reported one year after perichondrial grafting in rabbit knees $(67,71,94,95)$.

In 1990 Homminga et al. reported on twenty-five patients from a prospective study. In these patients, thirty chondral lesions of the knee were treated with an autogenous strip of perichondrium. (45) Graft fixation was done by using non-toxic, non-allergic 
and biodegradable fibrin glue $(73,101)$. After an immobilization period of two weeks in a plaster of Paris, the operated knee was subjected to continuous passive motion (89). Within one year post-operative increased density was seen on radiographs, indicating some degree of mineralization of the cartilage.

The purpose of this study is to assess which procedure to repair isolated cartilage defects gives the best results in the long-term; perichondrial transplantations or open debridements with drilling.

\section{PATIENTS AND METHODS}

Before starting this study, the following inclusion criteria were chosen: age under forty years, no previous drilling or shaving of the defect, no more than one graft at the time of operation and no more than osteoarthritis grade two in other parts of the knee (grading according to Dandy and Jackson) $(100,157)$.

From 1986 to 1992, fourteen patients with an articular cartilage defect were included in this study. They were treated with a perichondrial arthroplasty at The University Hospital of Maastricht and followed prospectively. The study was approved by the local ethics committee and was performed in accordance with the ethical standards laid down in the 1994 Declaration of Helsinki. An informed consent of the patients was obtained prior to inclusion in the study.

As a consequence of the use of the aforementioned criteria, only a limited number of patients could be included in this study. The patients that underwent debridement and drilling were selected from a parallel prospective study using the same inclusion criteria. From two relatively large groups of patients (PT 88, DB 150), only a few patients were included (PT 14, DB 11). The majority of patients suffered from more damage to the articular surface. This was also the case for patients under the age of forty. 


\section{Table I.}

Data on the patients: Perichondrial arthroplasty

\begin{tabular}{llrllllllll}
\hline Pat & Age $^{1}$ & FU $^{2}$ & Defect $^{3}$ & Size $^{4}$ & Tr $^{5}$ & PC $^{6}$ & PrHSS $^{7}$ HSS/ FU & HSS/ FU & & Remarks $^{8}$ \\
\hline 1 & 26 & 89 & R pat & 2.50 & - & 120 & 78 & $64 / 7$ & & Patellect \\
2 & 17 & 113 & L pat & 1.00 & + & 5 & 88 & $98 / 17$ & $100 / 113$ & \\
3 & 22 & 129 & R mfc & 3.00 & + & 12 & 57.9 & $92.5 / 12$ & $100 / 129$ & ACL rec \\
4 & 25 & 132 & R mfc & 1.50 & - & 15 & 72 & $97.5 / 12$ & $80 / 132$ & \\
5 & 22 & 94 & R pat & 2.50 & + & 36 & 64.5 & $88.5 / 12$ & $69 / 94$ & \\
6 & 36 & 85 & R pat & 2.25 & - & 36 & 80 & $97 / 11$ & $88 / 85$ & \\
7 & 35 & 142 & L mfc & 2.25 & - & 48 & 78.9 & $89.5 / 12$ & $97 / 142$ & Valg tib ost \\
8 & 37 & 103 & R mfc & 2.00 & - & 24 & 53 & $99 / 17$ & & Drilling \\
9 & 30 & 121 & R mfc & 6.25 & - & 24 & 72.6 & $78.5 / 25$ & & \\
10 & 22 & 115 & R pat & 2.00 & + & 24 & 79.8 & $100 / 17$ & $98 / 115$ & \\
11 & 27 & 127 & L mfc & 0.5 & - & 48 & 86.5 & $100 / 11$ & $94 / 127$ & \\
12 & 24 & 137 & L mfc & 3.75 & + & 4 & 63.3 & $95.5 / 11$ & $100 / 137$ & \\
13 & 21 & 100 & L mfc & 3.00 & - & 48 & 79 & $93.2 / 8$ & $99 / 100$ & \\
14 & 22 & 140 & R mfc & 1.50 & + & 26 & 75.5 & $87.5 / 16$ & $87 / 140$ & \\
\hline
\end{tabular}

Mean

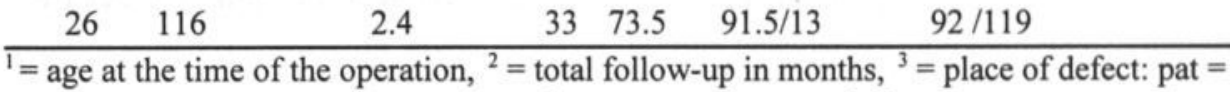
patella, $\mathrm{mfc}=$ medial femoral condyle, ${ }^{4}=$ size of defect in $\mathrm{cm}^{2},{ }^{5}=$ previous trauma, ${ }^{6}=$ preoperative duration of complaints in months, ${ }^{7}=$ Hospital for Special Surgery Score before the operation, ${ }^{8}=$ Hospital for Special Surgery Score at number of months post-operative, ${ }^{9}=$ patellectomy, anterior cruciate ligament reconstruction, valgus high tibial osteotomy

In the perichondrium group nine right and five left knees were treated in three women and eleven men. Most of the defects were situated in the medial femoral condyle (9). Five defects were grafted in the patella. The average defect size was $2.4 \mathrm{~cm}^{2}$. The average follow-up was nine years and eight months (range 85-140 months) and the average age was twenty-six years (Table I).

A second group of patients applying to the same inclusion criteria was chosen from another prospective study on debridements. These patients underwent open drilling of cartilage defects between 1978 and 1992. In the DB group six right and five left knees were treated in four women and seven men. Most defects were situated in the patella (6). Four defects were grafted in the medial femoral condyle and one in the lateral femoral condyle. The average defect size was $3.2 \mathrm{~cm}^{2}$. The average follow-up was 
eleven years (range 73-247 months) and the average age was thirty-one years (Table I).

This study was not randomized. Patients were selected from two different prospective studies; one on open debridement and drilling (1978-1992), and one on perichondrial arthroplasty (1986-1992). This explains the differences in follow-up in the debridement group. All patients complying to the inclusion criteria were also included.

\section{Operation technique perichondrial arthroplasty. The affected leg was} exsanguinated during general anaesthesia, the patient was in a supine position. The knee was opened through a medial parapatellar incision and the patella was dislocated laterally if necessary. The chondral lesion was identified and sharply cleaned until point-bleeding from the subchondral bone was visible. Point-bleeding was thought to provide for a cellular passage due to a better contact with the subchondral bone. The surrounding cartilage was cut in order to demarcate the lesion. An oblique incision was made over the lower part of the left side of the chest. The fascia of the rectus muscle was split transversely, and the muscle was split in the line of its fibres. Then the perichondrium was removed including its chondrogenic layer from the cartilaginous part of one of the lower ribs. The graft was cut to the size of the defect. In large defects sometimes two transplants were needed to cover the entire surface of the defect.

The graft was fixed with fibrin glue (Tissucol ${ }^{R}$, Immuno, Vienna). The perichondrial graft was placed on the subchondral bone with the chondral side facing the joint; it was then firmly pressed to the underlying bone with a wet gauze for one minute. The knee was moved to assess the fixation of the graft. The patella was relocated and the wound closed.

After an immobilization period of two weeks in a plaster of Paris, the graft was thought to be sufficiently attached and the operated knee was subjected to continuous passive motion for another two weeks $(73,74,89)$. Movement was encouraged, but for grafted lesions of the patella or the intercondylar groove the flexion was limited to $30^{\circ}$. Four weeks after the operation, patients were mobilized non-weight-bearing; active movements were encouraged. Full weight-bearing was started three months after the operation.

Operation technique debridement. The affected leg was exsanguinated during general anaesthesia, the patient was in a supine position. The knee was opened through a medial parapatellar incision and the patella was dislocated laterally if 
necessary. The chondral lesion was identified and cleaned. Thin drill holes were made using a $1.2 \mathrm{~mm}$ drill until point-bleeding from the subchondral bone was visible. After rinsing the knee with Ringers lactate, the patella was relocated and the wound closed. The aftertreatment consisted of four weeks non-weight-bearing, but active movements were encouraged. Full weight-bearing was started three months after the operation.

Analysis. The results were evaluated by means of the HSSS for knee function, by Xray examination and by a Visual Analogue Scale (VAS). The Hospital for Special Surgery Score by Ranawat et al. takes into account daily activities and a clinical and functional examination (76). The Visual Analogue Scale was used to measure pain while walking and pain at rest. The $\mathrm{X}$ - ray examination was performed during the last follow-up and compared to the situation one year after the operation. Signs of degenerative disease, calcification of the graft and irregularity of the operation surface site were noted. For statistical analysis, a paired $t$-test was used.

\section{RESULTS}

Three patients from the PT group were not included in the final assessment because of an additional operation interfering with the results (Table I). In patient number 1 the patella was removed after seventy-seven months because of incessant pain. This was done for an original defect of $2.50 \mathrm{~cm}^{2}$, followed by an unsuccessful debridement. Patient number 8 underwent a high tibial osteotomy after fifty-four months to reduce the undiminished pain in his medial compartment, based on a defect of $2.00 \mathrm{~cm}^{2}$ on his medial femoral condyle. In patient number 9 the loose rims of the graft were debrided and subchondral drilling was performed after fifty-six months. This patient was free of symptoms after this last procedure.

Patients: The mean age in the perichondrium group (Table I) was twenty-six years and the mean follow-up was 116 months. The average defect size was $2.4 \mathrm{~cm}^{2}$. One patient received an anterior cruciate ligament (bone-patella-bone) during the same procedure. This did not interfere with the treatment and after-treatment. The mean duration of complaints before the operation was thirty-three months. In 5/14 patients a trauma was the cause of the articular cartilage defect. In the other nine patients no cause of the defect could be detected. 


\section{Table II}

Data on the patients: Debridement

\begin{tabular}{|c|c|c|c|c|c|c|c|c|}
\hline \multicolumn{3}{|c|}{ Pat $\mathrm{Age}^{1} \mathrm{FU}^{2}$} & \multirow{2}{*}{$\begin{array}{l}\text { Defect }^{3} \\
\text { L mfc }\end{array}$} & \multirow{2}{*}{$\begin{array}{c}\text { Size }^{4} \\
0.25\end{array}$} & \multirow{2}{*}{$\begin{array}{l}\mathrm{Tr}^{5} \\
-\end{array}$} & \multirow{2}{*}{$\begin{array}{l}\mathrm{PC}^{6} \\
10\end{array}$} & \multicolumn{2}{|c|}{$\mathrm{PrHSS}^{7} \mathrm{HSS}^{8}$} \\
\hline 1 & 30 & 73 & & & & & 77 & 86 \\
\hline 2 & 28 & 75 & $\mathrm{~L} \mathrm{mfc}$ & 9 & - & 9 & 77 & 99 \\
\hline 3 & 36 & 223 & $\mathrm{R}$ lfc & 2.25 & - & 36 & 85 & 94 \\
\hline 4 & 38 & 205 & $\mathrm{R}$ pat & 2.25 & + & 48 & 76 & 99 \\
\hline 5 & 32 & 152 & $\mathrm{~L}$ pat & 1 & - & 36 & 68 & 84 \\
\hline 6 & 33 & 79 & $\mathrm{R}$ pat & 3 & + & 36 & 80 & 99 \\
\hline 7 & 37 & 247 & $\mathrm{~L}$ pat & 2.25 & - & 18 & 91 & 91 \\
\hline 8 & 31 & 79 & $\mathrm{R} \mathrm{mfc}$ & 8.75 & + & 3 & 26.4 & 97 \\
\hline 9 & 20 & 79 & R pat & 2.25 & + & 5 & 90 & 97 \\
\hline 10 & 25 & 80 & $\mathrm{~L} \mathrm{mfc}$ & 2.25 & + & 5 & 85 & 99 \\
\hline 11 & 32 & 165 & R pat & 2 & + & 48 & 91 & 97 \\
\hline$\overline{\mathrm{Mea}}$ & $\ln 31$ & 132 & & 3.2 & & 23 & 77 & 94.7 \\
\hline
\end{tabular}

${ }^{1}=$ age at the time of the operation, ${ }^{2}=$ total follow-up in months, ${ }^{3}=$ place of defect: pat: patella, mfc: medial femoral condyle, lfc: lateral femoral condyle, ${ }^{4}=$ size of defect in $\mathrm{cm}^{2}$, $5=$ previous trauma, ${ }^{6}=$ pre-operative duration of complaints in months, ${ }^{7}=$ Hospital for Special Surgery Score before the operation, ${ }^{8}=$ Hospital for Special Surgery Score at number of months post-operative.

In the debridement group (Table II) the mean age was thirty-one years and the mean follow-up 132 months. The average defect size was $3.2 \mathrm{~cm}^{2}$. One patient refused the $\mathrm{X}$-ray because of her pregnancy. The mean duration of complaints before the operation was twenty-three months. In 6/11 patients a trauma caused the articular cartilage defect. In the other five patients no cause of the defect could be detected.

HSSS: Fig. 2 and Table I and II: In the perichondrium group the mean HSS score changed from 73.5 before the operation to 92 after the last follow-up. In the debridement group the HSS score changed from 77 to 94.7. No significant difference could be detected with the numbers available. The difference in HSS score measured before the operation and after ten years was in both groups approximately the same. The PT group improved somewhat more than the DB group although no trend was seen (PT 18.5- DB 17.7). 
VAS: Figure 1 and Table III: The VAS for walking improved in the perichondrial group from 2.8 after one year to 2.0 after ten years. In rest the scores changed from 1.8 to 0.9 . In the debridement group after ten years the results for walking were 1.1 and in rest 0.7 . No significant difference could be detected with the numbers available.

\section{Figure 1}

Visual Analogue Scale

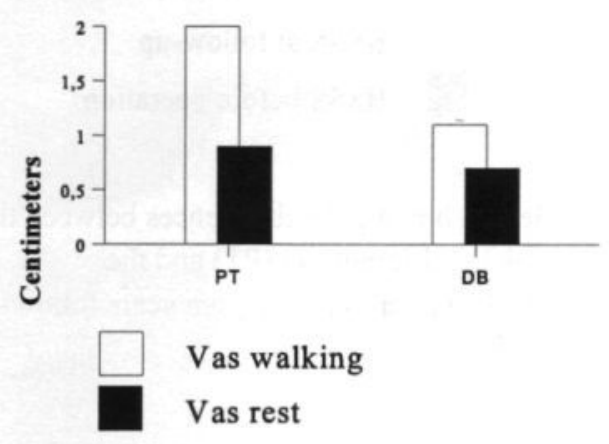

Graph showing the differences between the perichondriumgroup (PT) and the debridementgroup (DB) ten years follow-up

$\mathrm{X}$-ray examination: Table IV: X-ray examinations showed increases in subchondral sclerosis. In the PT group this was the case in 3/11 patients and in the DB group 4/10. More spurs were seen in the DB group 4/10 as compared to the PT group 3/11. Irregularities were seen as calcifations of the graft, or subchondral sclerosis and thickening of the debrided site. In the PT group 9/11 X rays showed marked irregularities and in the DB group these were seen in $8 / 10$ of the cases. The changes were seen at the same extent in both groups at the last follow-up (Figs 3,4).

Clinical examination: All patients underwent a clinical examination. The results of these examinations are already incorporated in the HSS score. One of the fourteen patients who underwent a perichondrium transplantation still had pain on the donor site (rib). 


\section{Figure 2}

Hospital for Special Surgery Score

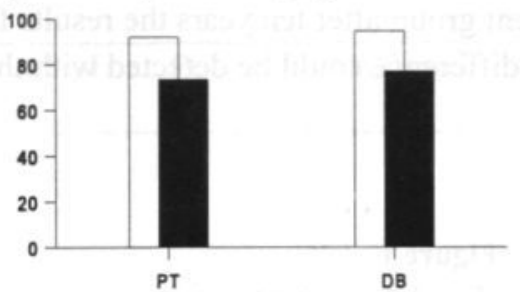

HSSS at follow-up

HSSS before operation

Graph showing the differences between the perichondriumgroup (PT) and the debridementgroup (DB) ten years follow-up

\section{Table III}

Data on the patients: Visual Analogue Scale

\begin{tabular}{llllll}
\hline Pat Grp $^{1}$ & Wlk $/$ Rst $^{2}$ at $\mathrm{FU}^{3}$ Wlk/Rst atFU & Remarks & Pat & Grp $^{1}$ & Wlk/Rst
\end{tabular}

\begin{tabular}{rrrrrrllllr}
\hline 1 & PT & $7.5 / 7.0$ & 7 & & & Patellectomy & 1 & DB & $4.4 / 2.9$ & 73 \\
2 & PT & $0.7 / 0.0$ & 17 & $0.2 / 0.3$ & 113 & & 2 & DB & $0.7 / 0.2$ & 75 \\
3 & PT & $3.0 / 2.5$ & 12 & $0.0 / 0.0$ & 129 & & 3 & DB & $1.2 / 0.4$ & 223 \\
4 & PT & $3.5 / 3.0$ & 12 & $2.0 / 0.5$ & 132 & & 4 & DB & $0.3 / 0.3$ & 205 \\
5 & PT & $1.6 / 0.0$ & 12 & $8.1 / 4.6$ & 94 & & 5 & DB & $4.0 / 3.7$ & 152 \\
6 & PT & $0.7 / 0.4$ & 11 & $3.8 / 0.2$ & 85 & & 6 & DB & $0.0 / 0.0$ & 79 \\
7 & PT & $6.0 / 5.3$ & 12 & $4.3 / 3.7$ & 142 & & 7 & DB & $0.1 / 0.1$ & 247 \\
8 & PT & $0.2 / 0.1$ & 17 & & & Valg tib ost & 8 & DB & $0.2 / 0.3$ & 79 \\
9 & PT & $4.7 / 0.6$ & 25 & & & Drilling & 9 & DB & $1.2 / 0.0$ & 79 \\
10 & PT & $0.0 / 0.0$ & 17 & $0.2 / 0.1$ & 115 & & 10 & DB & $0.0 / 0.0$ & 80 \\
11 & PT & $2.5 / 2.6$ & 11 & $2.3 / 0.2$ & 127 & & 11 & DB & $0.0 / 0.0$ & 165 \\
12 & PT & $6.0 / 4.0$ & 11 & $0.0 / 0.0$ & 137 & & & & & \\
13 & PT & $0.0 / 0.0$ & 8 & $0.0 / 0.0$ & 100 & & & & & \\
14 & PT & $3.0 / 0.0$ & 16 & $1.4 / 0.0$ & 140 & & & & & \\
\hline Mean & $2.8 / 1.8$ & 13 & $2.0 / 0.9$ & 119 & & & DB & $1.1 / 0.7$ & 132 \\
\hline
\end{tabular}

$1=$ PT: perichondrial arthroplasty group, DB: debridement group, ${ }^{2}=$ Visual analogue scale for walking and in rest, ${ }^{3}=$ Follow-up in months. 


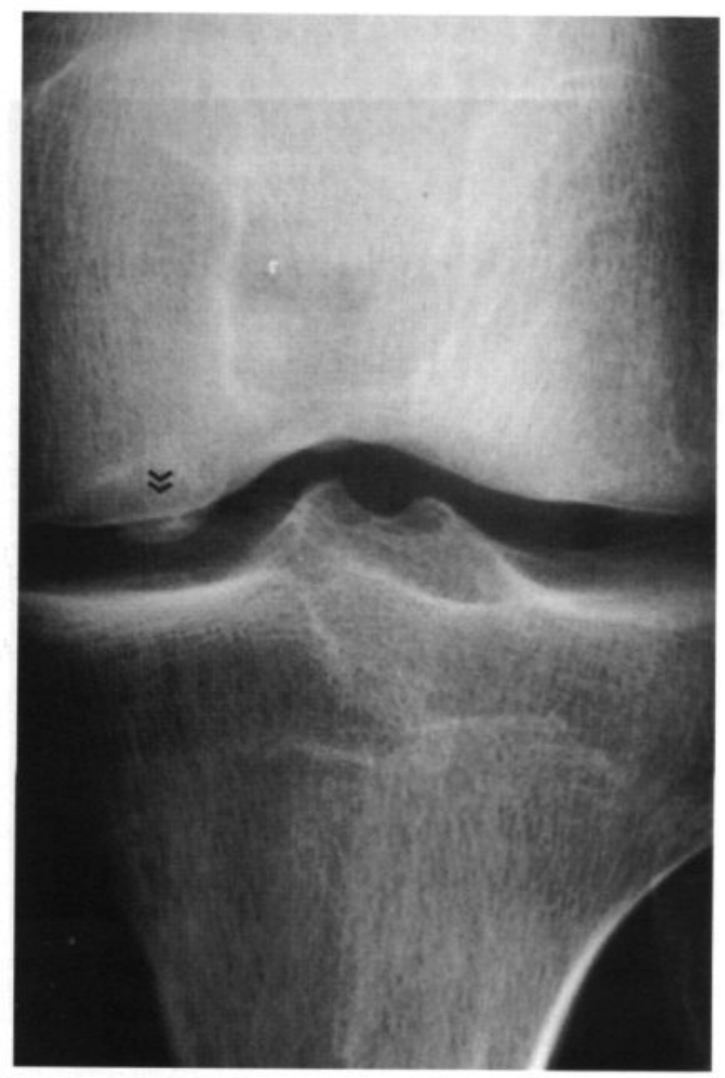

Figure 3. X ray of patient from PT group. $\gg>=$ calcification of the graft/subchondral sclerosis on the medial femoral condyle. $\mathrm{X}$ ray taken after 85 months follow-up.

\section{DISCUSSION}

In this study the long-term effects of a perichondrial arthroplasty versus an open debridement were examined. In a previous prospective study criteria were put forward whereby this procedure could be performed with a success rate of approximately $90 \%$. Perichondrial or periosteal arthroplasty are the only experimental procedures thusfar that result in repair of cartilage defects with hyaline-like cartilage $(156,158)$. It was considered important to know whether this experimental technique performed better clinically in the long-term compared to the generally used debridement procedure. 


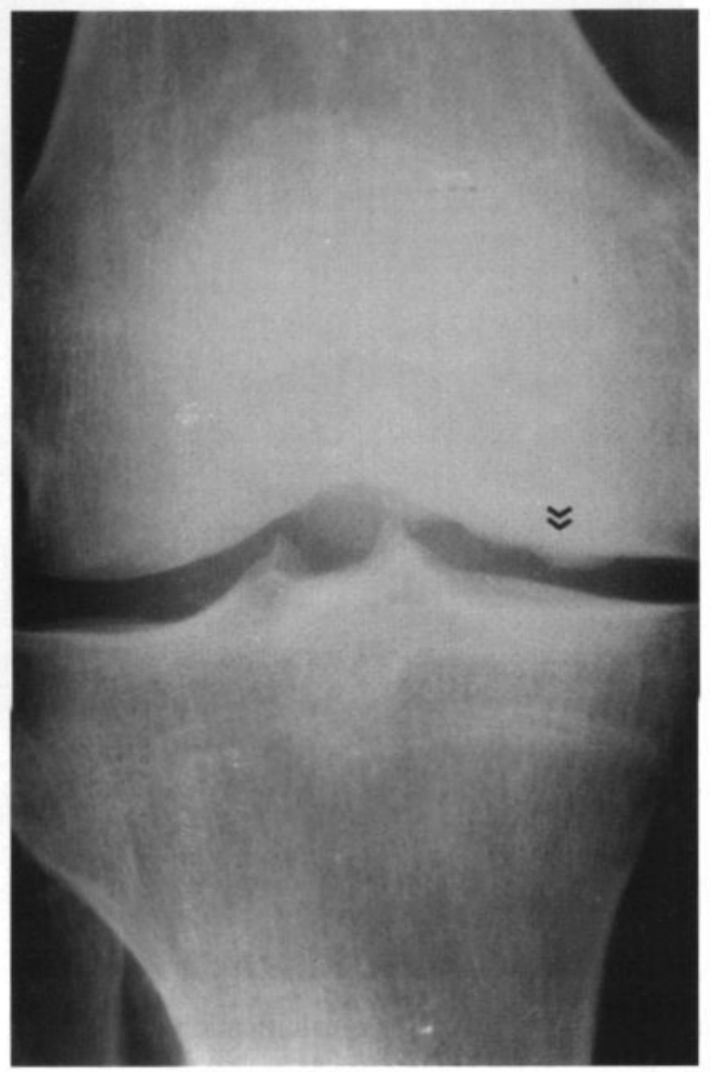

Figure 4. $\mathrm{X}$ ray of patient from DB group. $>>=$ calcification of the repair tissue/subchondral sclerosis on the medial femoral condyle. $\mathrm{X}$ ray taken after 80 months follow-up.

Three patients were lost at the last follow-up (Table I). Patient number 1 underwent two operations after the perichondrial grafting: during the first operation thirty-eight months later, a debridement of the patella was done. A second operation was performed because of consistent pain after seventy-seven months: the patella was removed completely. This patient was still not satisfied after the last procedure. Patient number 8 underwent a high tibial osteotomy after fifty-four months. His pain subsided, but only for one year. Overall his complaints were less compared to the situation before the perichondrial transplantation. In patient number 9 , drilling in the 
original transplantation site was performed after fifty-six months. After this procedure he was satisfied.

Shortcomings of the perichondrial arthroplasty technique are calcification of the graft and delamination of the cartilage (153). These are potentially significant limitations to the long-term efficacy of the technique. Both these topics were studied and attempts for improvements have been made. Studies to strengthen the bond between the graft and the host tissue by implantation of biodegradable, biocompatible polymers, or enzymatic treatment of the host tissue have been undertaken $(7,166)$. Nowadays patients receive indomethacin to reduce the calicification of the graft. This improves the durability and visco-elastic properties of the graft. By using indomethacin to prevent excessive calcification, the results in the future will hopefully improve, although calcification may play an important role in the fixation of the graft.

Healthy articular cartilage can stand a high amount of intensive and repetitive stress. However, the capacity to repair even the smallest injury is surprisingly low. The respons of cartilage to injury differs from that of other tissues because of the lack of vascular tissue, the immobility of chondrocytes, and the limited ability of mature chondrocytes to proliferate $(159,160)$. Debridement and drilling results in mechanically inferior fibrocartilagenous tissue. Differences in quality of repair tissue have been described using different sizes of drills (20). In our debridement group 1.2 $\mathrm{mm}$ drills were used on the basis of data in literature. These drills were used because better hyaline-like repair tissue was seen with this size. In this way both groups were compared using the best treatment modalities available.

Radiographs taken post-operatively of patients who underwent a PT, showed calcification of the graft in a considerable number of cases. Plenk and Passl suggested that the mineralization of the basal layer of newly formed cartilage is increased compared with normal cartilage $(91,102)$. This increased mineralization may have a negative impact on the visco-elastic properties of the cartilage and on its durability.

Dzioba described a study in which sixty-five articular cartilage lesions were treated by complete vertical excision of diseased or injured articular cartilage followed by drilling of the subchondral bone plate. The overall clinical results after two years were $69 \%$ good, $3 \%$ fair and $28 \%$ poor (21). In another study by Timoney et al.

debridement of the knee was performed in 109 patients (111 knees). After a mean follow-up of 50.6 months, arthroscopic debridement offered measurable relief for $63 \%$ of the patients for a significant period of time (19). Menche et al. compared abrasion 
burr arthroplasty and subchondral drilling in rabbits and found that, although both techniques were suboptimal, after 6 months, subchondral drilling resulted in a longerlived repair than abrasion arthroplasty in the treatment of full-thickness lesions (165).

The results of the debridement group where open drilling had been the procedure seem somewhat better than according to literature, but one must keep in mind that only a selected group of patients was included. Patients younger than 40 years seem to do better almost regardless of which treatment had been offered. Nowadays all debridements are performed arthroscopically because of a number of reasons. The morbidity of an arthroscopical procedure is lower and patients can return to work earlier. These issues carry big advantages seen economically. Perichondrial arthroplasty will always carry the disadvantages of an arthrotomy. Next to that, perichondrial arthroplasty requires a second operation area, the rib. In the case of a periosteum transplantation, one incision can be used for harvesting and transplanting the graft. If the long-term results are at least equal to those of perichondrial transplants, periosteum transplantation would eventually be preferrable (82).

To justify the disadvantages compared to arthroscopic debridements, superior results of perichondrial transplantation in the long-term are required. Ten years after the treatment this does not seem to be the case. However, considering the age of the patients at the time of treatment a longer follow-up may be necessary to illustrate the potential and theoretical advantages of perichondrial arthroplasty over debridement and drilling.

In conclusion, perichondrial arthroplasty used to repair isolated articular cartilage defects does not show better clinical results than open debridement and drilling after ten years.

In order to establish the value of the theoretical advantages of perichondrium transplantation, longer follow-up will be necessary.

To achieve useful evaluations, this should be done in randomized prospective studies with sufficient numbers of patients and extreme long follow-up periods. In patients with more or larger cartilage defects, perichondrial arthroplasty has shown to be less successful than drilling. In the selected groups of this study, both treatments are equal. Improving the results of debridement and drilling will be difficult. For the time being we prefer the drilling procedure as the golden standard for articular cartilage defects. 


\section{CHAPTER 11}

\section{Discussion}

No common evaluation system of postsurgery results in cartilage repair and no accepted classification system regarding the description of cartilage defects exists. Therefore it is difficult to compare the results of different cartilage treatments. A complete evaluation of cartilage repair is possible only if biopsies are taken. Of great importance is the fact that results from animal studies may not be easily extrapolated to humans. Many differences exist like cartilage thickness, cell concentration, structure and so on.

Despite many studies, no good technique has been found to generate the genuine hyaline cartilage. The histological results are often disappointing, although many different techniques are used. It still remains controversial whether the histological result is more important than the clinical result. A good example of this was the use of woven carbon fiber implants in drilled lesions. The resulting repair tissue was fibrocartilaginous. Cartilage was not regenerated using this technique, but pain subsided and function improved in most patients (173).

Until now, the clinical results were reasonable, whereas the histological results were dubious. In which direction we have to go in order to deal with this problem remains the question. Is it better to produce cartilage of a better quality, like with the use of stem cells or tissue engineering? Or is it better to focus on complete synthetic replacement of the cartilage? Or is the key to this answer primary prevention of damage?

Another way of approaching the subchondral bone is by using synthetic materials. The subchondral bone carries the loads transmitted by the cartilage, and defects predispose for degenerative disease. Many synthetic bone grafts substitutes like Polyactive $^{\mathrm{TM}}$ have been used to repair the subchondral bone. Other synthetic bone grafts like hydroxyapatite and the resorbable tricalcium phosphate have been used as a 
scaffold (129). Improvements in pore configuration, mechanical properties and osteoinductive capacity of synthetic bone grafts substitutes should widen their future clinical application.

One way of preventing more damage to the cartilage after an isolated cartilage defect has emerged, might be the protection of the surface of the cartilage. Aggrecan is thought to leak from the superficial layers of the cartilage, thereby further damaging the structural integrity. Some studies were performed with chondrocyte protectants like hyaluronate, arteparon or rumalon $(171,172,178)$. Hyaluronate seems promising to prevent deterioration of cartilage damage in an early stadium. These studies are still speculative. Perhaps these therapies can stand alone in specific cases, or as additional therapies to a more fundamental repair process.

It may be important to focus more on the natural biomechanical environment and mechanisms. Until now not much attention has been paid to this issue. Biomechanical testing is difficult and not very often performed when reviewing the literature.

Although it is hard to realize in human studies, in the future this will become more and more important. Dynamic compression after a surgical procedure to repair cartilage could improve the results. It is critical to obtain some mechanical information beyond simple palpation with a probe.

Much attention is paid nowadays to techniques using, for example, growth hormones, tissue engineering or osteochondral progenitor cells. The biomechanical environment has to be taken into account as an important factor.

Growth hormones can possess very divers working mechanisms, if known at all. They have a chondrogenic effect on immature cartilage. Transforming Growth Factor- $\beta$ for example upregulates the expression of Type II collagen mRNA's. The optimum dose is important; a relative overdose inhibits these processes (174).

Insulin growth Factor 1 (IgF-1) alone stimulates chondrocytes DNA and proteoglycan synthesis. Growth hormone alone has no effect on either process, whereas when both hormones are used at the same time, more proteoglycan synthesis and keratan sulphate is seen than by using IgF-1 alone (176).

Osteogenic protein 1 (OP-1, BMP-7) is known to stimulate cartilage differentiation of human perichondrium tissue in vitro. The effect of Interleukin 1 (IL-1) on chondrocyte function is negative: there is a decreased repair and an increase in degradation fragments of the matrix. IL-1 together with OP-1 restores the proteoglycan synthesis (175). 
It is essential to know the exact working mechanism of each of these hormones before they can be used in human clinical studies. Combining different hormones may induce beneficial reactions.

Cartilage which does not repair itself and bone which does, are derived from a common progenitor cell. The use of mesenchymal stem cells acting as osteochondral progenitor cells derived from the periosteum or bone marrow is in an early research stage. By using the recapitulation of embryonic events starting with an uncommitted progenitor cell population, cartilage formation can be induced. The optimum number of appropriate cells has to be established as well as a suitable, flexible and supportive vehicle. Because cartilage has no vascular supply or easy access to the progenitors, sufficient numbers of progenitor cells have to be brought to the repair site.

Because the defect encompasses the subchondral bone and the cartilage, the reparative cells must be situated in such way as to provide repair for both of these very different types of skeletal tissue. Pluripotential cells embedded in Type I collagen gel showed a filled defect with vascularized bone up to the bone-cartilage junction. A normal calcified zone of cartilage and tidemark did not develop (177). Some studies in rabbits did show a tidemark. Here a polyglycolic acid polymer matrix was used for implantation together with mesenchymal stem cells from skeletal muscle. It is clear that extensive research still has to be done.

Tissue engineering has emerged as a potentially new therapy in which synthetic materials seeded with appropriate cell populations are grown in vitro and subsequently implanted into patients. Perhaps in a few years, entire femoral condyles can be reproduced by using chondrocyte-polymer composites with specific three-dimensional shapes.

In the future more will be heard of the recently emerged gene therapy. Not much is known yet about this technique, although many preclinical studies are performed. The infection of chondrocytes with adenovirusses carrying growth factors could bring about an enormous step forward in the repair of cartilage.

Thus far, none of the methods of treating chondral defects have shown to stimulate formation of tissue that duplicates the structure, composition, mechanical properties and durability of articular cartilage and none of them have been evaluated in controlled prospective studies. 
Advances are being made on a number of fronts. Perhaps some combination of chondrocyte transplantation, bioabsorbable polymer to direct the distribution of chondrocytes, and pharmocologic intervention will combine to yield a satisfactory solution. Other biotechnologies include combining growth factors with synthetic matrices and cell and tissue transplants, use of electromagnetic fields, ultrasound and controlled loading and motion.

Orthopaedic surgeons must carefully assess new technologies and expect the highest quality of scientific evidence before recommending new procedures to their patients. To adopt a new form of treatment enthusiastically, we must be certain that it is better than existing modalities, and that it has the prospect of maintaining good results over time. 


\section{SUMMARY}

Chapter 1 deals with some aspects of the biology and structure of normal articular cartilage. The processes occurring during wound healing in articular cartilage and the problems encountered in the repair of articular cartilage defects are discussed. A short survey of repair techniques is given.

In chapter 2, methods of biological repair are mentioned, varying from osteotomies, drilling or shaving to different grafting techniques. Some advantages and disadvantages of osteochondral allografts and autografts are shown. Cell transplantation techniques like chondrocyte transfer or mesenchymal stem cell transfer are discussed. Finally, some aspects concerning the use of periosteum, perichondrium and artificial scaffolds are given.

The history of perichondrial arthroplasty is highlighted in chapter 3. Already in 1878 the potential of perichondrium to form cartilage was documented. Application of perichondrium started in 1972, when rabbit ear perichondrium was used. Until now many researchers used perichondrium in different clinical and animal studies with varying successes.

The aims of this thesis are discussed in chapter 4. An important question is why some patients performed so well after they had undergone a perichondrial arthroplasty and why others did not. Fixation and calcification problems had to be studied as well as the best criteria for performing a perichondrial arthroplasty. Finally, the most important question was which technique was superior: perichondrial arthroplasty or the old-fashioned debridement and drilling.

Chapter 5 describes perichondrial grafting for cartilage lesions of the knee in twentyfive patients with 30 chondral lesions. The mean Hospital for Special Surgery knee Score (HSSS) changed from 73 before the operation to 90 one year after; in 14 patients evaluated after two years there was no decrease. We concluded that in most cases, perichondrial arthroplasty of cartilage defects in the knee gave excellent shortterm results. 
In chapter 6 the long-term results of rib perichondrial grafts for the repair of articular cartilage defects in the human knee were studied. Eighty-eight patients operated upon between 1986 and 1992 were evaluated by assessing knee function, radiographs, arthroscopy and the patient's subjective opinion. The results after a mean follow-up of 52 months were good in $38 \%$, fair in $8 \%$ and poor in $55 \%$. Failures were caused by growth of the graft above the surrounding cartilage, which also felt hard at arthroscopy. Previous drilling or shaving of a defect, concomitant osteoarthritis, older age and a long history of complaints proved to be contra-indications. Good results were seen in $91 \%$ of isolated defects.

In order to improve the fixation and to prevent the calcification of the perichondrial graft some studies were performed with a polymer. Chapter 7 describes the use of Polyactive $^{\mathrm{TM}}$ (PA) as a bone-filling substance. An experimental study in rabbits was performed and the biocompatible, osteoconductive and resorbable polymer was investigated for its performance as a bone-graft substitute. PA70/30 and PA60/40 were investigated, both before and after being incubated with allogenic bone marrow. Dual energy X-ray absorptiometry (DXA) and image analysis of histological sections were performed. DXA revealed an increased bone mineral density in the filled defects compared to the controls, both at the defect and immediately proximal and distal of the defect. PA70/30 seemed to be more suitable compared to PA60/40, because the highest amount of bone was formed within the shortest period of time. Incubation of PA with allogenic bone marrow resulted in inflammatory reactions at the sites of implantation. The conclusion was that PA70/30 and PA60/40 were suitable bone-graft substitutes.

In chapter 8 quantitative histological analysis of bony ingrowth was performed within Polyactive ${ }^{\mathrm{TM}}$ implanted in different bone locations. PA60/40 was implanted in three different bone locations in the rabbit: in the cortex, in bone marrow and in trabecular subchondral bone. The ingrowth of bone was investigated by histology and image analysis and was observed in the PA60/40 placed in the cortex from 4 weeks onwards. After 8 weeks, more than $90 \%$ of the pores of the biomaterial were filled with dense bone. In bone marrow, initially some bone formation was seen, but after 26 weeks, all newly formed bone was resorbed. Subchondral bone formation was less than in the cortex of the femur, but somewhat comparable to the amount of bone found in healthy trabecular bone. Degradation of the biomaterial did not affect bone formation. 
Chapter 9 describes the results of 22 biopsies of tissue formed after approximately one year after a perichondrium transplantation. This operation was performed from 1986 to 1992 on 88 patients (introduced in chapter 6) with articular defects in the knee. Biopsies were only taken when at that time a partial failure was present, or a clear failure resulting in fibrocartilage, a loose flap or a loose body. Histological analysis showed the presence of normal hyaline cartilage in 11/22 patients. Biochemical analysis showed that more than $56 \%$ of the collagen present was type II collagen. Biopsies from patients with an isolated cartilage defect and an otherwise healthy knee showed normal hyaline cartilage in $93 \%$ (13/14) of the cases. Analysis of biopsies from failed transplants found in patients with additional anomalities in the knee showed fibrocartilage with mainly type I collagen.

Chapter 10 describes the ten year follow-up of human perichondrial grafting versus debridement and drilling of cartilage defects in the knee. From 1986 to 1992, the already described group of eighty-eight patients with articular cartilage defects in the knee were treated with a perichondrial transplantation (PT). Fourteen patients met the revised inclusion criteria: age under forty years, no previous drilling or shaving of the defect, no more than one graft at the time of operation and no more than osteoarthritis grade two in other parts of the knee. Using the same inclusion criteria, a second group of eleven patients was formed, who underwent an arthrotomy and debridement and drilling of the cartilage defect. The results of both procedures after ten to eleven years were evaluated with the Hospital for Special Surgery knee Score, X-ray examination, by clinical examination and by Visual Analogue Scale. This study shows that ten years after treatment, perichondrium transplantation does not do better than open debridement and drilling.

Chapter 11 of this thesis is the discussion. Here some reflections are given on the future possibilities of dealing with articular cartilage defects. The most important issue is the fact that orthopaedic surgeons must carefully look for scientific evidence before recommending new procedures to their patients. To offer a new form of treatment, we must be certain that it is better than existing modalities, and that the results maintain good over time. 


\section{SAMENVATTING}

Hoofdstuk 1 geeft een overzicht van enkele aspecten van de biologie en de structuur van normaal gewrichtskraakbeen. De processen die optreden bij wondgenezing in gewrichtskraakbeen met de bijbehorende problemen worden beschreven. Een kort overzicht wordt gegeven van operatieve technieken.

In hoofdstuk 2 worden de operatieve mogelijkheden voor het herstel van kraakbeendefecten beschreven. Enkele voor- en en nadelen van osteochondrale allografts en autografts komen aan bod. Technieken waarbij gebruikt wordt gemaakt van transplantatie van cellen, zoals chondrocyten en mesenchymale cellen, worden toegelicht. Tot slot volgen enkele opmerkingen over het gebruik van periosteum, perichondrium en artificial scaffolds.

De geschiedenis van de transplantatie van perichondrium wordt belicht in hoofdstuk 3. $\mathrm{Al}$ in 1878 werd de potentie van perichondrium om kraakbeen te vormen gerapporteerd. Klinische toepassing van perichondrium begon in 1972 toen perichondrium van het oor van een konijn werd gebruikt. Tot nu toe hebben vele onderzoekers perichondrium met wisselend succes gebruikt in klinische onderzoeken en experimenten met dieren.

Het doel van dit proefschrift wordt beschreven in hoofdstuk 4. Een belangrijke vraag is waarom sommige patiënten het zo goed deden na een perichondrium transplantatie en anderen niet. De fixatie en de verkalking van perichondrium transplantaten alsmede de beste criteria voor het uitvoeren van deze operatie moesten worden onderzocht. De belangrijkste vraag was welke operatie de voorkeur verdiende: de perichondrium transplantatie of de aloude operatie waarbij het subchondrale bot wordt opgeboord.

Hoofdstuk 5 beschrijft een studie waarin 25 patiënten met 30 kraakbeenletsels werden geopereerd door middel van een perichondrium transplantatie. De gemiddelde kniescore (Hospital for Special Surgery knee Score, HSSS) nam toe van 73 voor de operatie tot 90 een jaar later. In 14 patiënten die na twee jaar geëvalueerd werden, werd geen verslechtering geconstateerd. Onze conclusie was dat perichondrium 
transplantaties voor kraakbeendefekten in de meeste gevallen uitstekende korte termijn resultaten gaven.

De resultaten op lange termijn van perichondrium transplantaten voor het herstel van kraakbeendefekten worden beschreven in hoofdstuk 6. Achtentachtig patiënten die geopereerd werden tussen 1986 en 1992 werden geëvalueerd. Er werd gebruik gemaakt van klinisch onderzoek, röntgenfoto's, arthroscopieën en de subjectieve mening van de patiënten. Na een follow-up van gemiddeld 52 maanden waren de resultaten bij $38 \%$ van de patiënten goed, matig bij $8 \%$ en slecht bij $55 \%$.

Transplantaten die faalden groeiden uit boven het niveau van het kraakbeen in de omgeving en voelden hard aan tijdens de arthroscopie. Contra-indicaties voor het uitvoeren van deze operatie waren voorafgaande operaties zoals nettoyage of opboren van het defekt, reeds aanwezige arthrose ten tijde van de operatie, leeftijd hoger dan 40 en een langere voorgeschiedenis. Een goed resultaat werd gevonden bij $91 \%$ van de patiënten met een geïsoleerd defect.

Met het doel de fixatie te verbeteren en de calcificatie tegen te gaan werd een studie verricht met een polymeer. Hoofdstuk 7 beschrijft het gebruik van Polyactive ${ }^{\mathrm{TM}}$ (PA) als een middel om botdefekten te vullen. Er werd experimenteel onderzoek verricht in konijnen. De biocompatibele, botgeleidende en resorbeerbare eigenschappen van Polyactive $^{\mathrm{TM}}$ (PA) werden onderzocht. PA 70/30 en PA 60/40 werden gebruikt, beide voor en na te zijn geïncubeerd met allogeen beenmerg. Dual energy X-ray absorptiometrie (DXA) en image analysis van histologische coupes werd uitgevoerd. DXA liet een toename zien van de botdichtheid in de gevulde defekten vergeleken met de controles; in het defekt, proximaal en distaal hiervan. PA 70/30 gaf de indruk beter bruikbaar te zijn dan PA 60/40, omdat het meeste bot werd gevormd in de kortste tijd. Incubatie van PA met allogeen beenmerg gaf ontstekingsreacties in het gebied van implantatie. De conclusie van dit onderzoek was dat zowel PA 70/30 als PA 60/40 bottransplantaties kunnen vervangen.

In hoofdstuk $\mathbf{8}$ is kwantitatieve, histologische analyse verricht van de ingroei in bot van Polyactive ${ }^{\mathrm{TM}}(\mathrm{PA})$ geïmplanteerd in verschillende lokaties. PA 60/40 werd in drie verschillende locaties getransplanteerd: in de cortex, in het merg en in het subchondrale bot. De ingroei van bot werd geëvalueerd door histologie en image analysis. Ingroei van bot in PA 60/40 geïmplanteerd in de cortex werd gezien vanaf 4 weken. Na 8 weken was meer dan $90 \%$ van de porieën van het biomateriaal gevuld met bot. In het beenmerg werd aanvankelijk ook botvorming gezien, echter na 26 
weken was dit geheel verdwenen. De botvorming in PA 60/40 in het subchondrale bot was minder dan in de cortex, maar wel vergelijkbaar met de botvorming die in gezond spongieus bot werd gevonden. Degradatie van het biomateriaal had geen nadelige effecten op de vorming van bot.

Van 1986 tot 1992 werden 88 patiënten (geëntroduceerd in hoofdstuk 6) met kraakbeendefecten behandeld met een perichondrium transplantatie. Hoofdstuk 9 beschrijft de resultaten van 22 weefselbiopten gevormd door het perichondrium na ongeveer een jaar. Er werden alleen biopten genomen als er sprake was van loslating van het transplantaat, een evident slecht resultaat door de vorming van fibreus kraakbeen of een corpus liberum. Histologische evaluatie liet de aanwezigheid van normaal hyalien kraakbeen zien in 11/22 patiënten. Uit de biochemische analyse kwam naar voren dat meer dan $56 \%$ van het aanwezige collageen van het type II was. Biopten van patiënten met een geïsoleerd kraakbeendefect en voor de rest niet afwijkend gewricht lieten hyalien kraakbeen zien in 93\% (13/14) van de gevallen. Analyse van de biopten van mislukte transplantaten die genomen waren bij patiënten met additionele afwijkingen in de knie lieten fibreus kraakbeen zien met hoofdzakelijk type II collageen.

Hoofdstuk 10 beschrijft de resultaten van een vergelijkende studie na tien jaar tussen perichondrium transplantaties en nettoyages waarbij het defect werd opgeboord. Veertien patiënten van de voornoemde 88 voldeden aan de criteria die van te voren werden opgesteld: leeftijd lager dan veertig jaar, geen voorgeschiedenis van nettoyage of opboren, niet meer dan één defect ten tijde van de operatie en niet meer dan arthrose graad 2 in de rest van de knie. Een tweede groep van patiënten die voldeden aan dezelfde inclusie criteria werd gevormd uit patiënten die een open nettoyage met opboren van het defect hadden ondergaan. De resultaten van de beide operaties na tien jaar werden geëvalueerd door middel van de Hospital for Special Surgery knee Score, röntgenonderzoek, klinisch onderzoek en door het gebruik van een Visual Analogue Scale. Uit deze studie kwam naar voren dat de resultaten na tien jaar van perichondrium transplantaties niet beter waren dan die van open nettoyages waarbij het defect werd opgeboord.

Hoofdstuk 11 beschrijft mogelijke toekomstige behandelingen voor kraakbeendefekten. Het belangrijkste blijft echter de kritische blik van de orthopaedisch chirurg naar de wetenschappelijke waarde en de lange termijn resultaten van hetgeen wordt gepresenteerd voordat dit aan patiënten wordt aangeboden. 


\section{REFERENCES}

1. Horton WA: Morphology of connective tissue: cartilage. In: Connective tissue and its heritable disorders, ed by PM Royce, B Steinmann, New York, Wiley-Liss, Inc.:73-84, 1993

2. Lapiere $\mathrm{CM}$, Nusgens $\mathrm{B}$ : Mechanical powers are responsible for differentiation of fibroblasts cultured within a 3 dimensional collagen support. In: Hybrid Artificial Organs: Concepts and Development, ed by C Baquey, B Dupuy, Paris, Institut National Sante Recherche Medicinale:77-90, 1989

3. Mow VC, Holmes MH, Lai WM: Influence of load bearing on the fluid transport and mechanical properties of articular cartilage. In: Joint Loading. Biology and Health of Articular Structures, ed by HJ Helminen, I Kiviranta, M Tammi, A-M Saamanen, K Paukkonen, J Jurvelin, Bristol, Wright:264-286, 1987

4. Pollesello P, D'Andrea P, Martina M, de Bernard B, Vittur F: Modification of plasma membrane of differentiating preosseous chondrocytes. Evidence for a degradative process in the mechanism of matrix vesicle formation. Exp Cell Res 188(2):214-218, 1990

5. Korver THV, van de Stadt RJ, Kiljan E, van Kampen GPJ, van der Korst JK: Effects of loading on the synthesis of proteoglycans in different layers of anatomically intact articular cartilage in vitro. J Rheumatol 19(6):905-912, 1992

6. Hunziker EB: Articular cartilage structure in humans and experimental animals. In: Articular cartilage and osteoarthritis, ed by KE Kuettner, R Schleyerbach, JG Peyron, VC Hascall, New York, Raven Press:183-199, 1992

7. Hunziker EB, Kapfinger E: Removal of proteoglycans from the surface of defects in articular cartilage transiently enhances coverage by repair cells. J Bone Joint Surg 80B(1):144-150, 1998

8. Mankin HJ: The response of articular cartilage to mechanical injury. J Bone Joint Surg 64-A(3):460-468, 1982

9. Convery FR, Akeson WH, Keown GG: The repair of large osteochondral defects. Clin Orthop 82:253-262, 1972

10. Key JA: Experimental arthritis: the changes in joints produced by creating defects in the articular cartilage. J Bone Joint Surg Am 13:725-739, 1931

11. Meachim G, Roberts C: Repair of the joint surface from subarticular tissue in the rabbit knee. J Anat 109(2):317-327, 1971

12. Mitchell N, Shepard $\mathrm{N}$ : The resurfacing of adult rabbit articular cartilage by multiple perforation through the subchondral bone. J Bone Joint Surg 58-A(2):230-233, 1976 
13. Insall JN: The Pridie debridement operation for osteoarthritis of the knee. Clin Orthop 101(01):61-67, 1974

14. Coventry MB, Ilstrup DM, Wallrichs SL: Proximal tibial osteotomy. J Bone Joint Surg 75-A(2):196-201, 1993

15. Akizuki S, Yasukawa Y, Takizawa T: Does arthroscopic abrasion arthroplasty promote cartilage regeneration in osteoarthritic knees with eburnation? A prospective study of high tibial osteotomy with abrasion arthroplasty versus high tibial osteotomy alone. Arthroscopy 13(1):9-17, 1997

16. Coletti JM Jr, Akeson WH, Woo SL-Y: A comparison of the physical behavior of normal articular cartilage and the arthroplasty surface. J Bone Joint Surg 54-A(1):147160,1972

17. Mitchell N, Shepard N: Effect of patellar shaving in the rabbit. J Orthop Res 5:388-392, 1987

18. Kim HKW, Moran ME, Salter RB: The potential for regeneration of articular cartilage in defects created by chondral shaving and subchondral abrasion. J Bone Joint Surg 73A(9):1301-1315, 1991

19. Timoney JM, Kneisl JS, Barrack RL, Alexander H: Arthroscopy in the osteoarthritic knee. Long-term follow-up. Orthop Rev 19(4):371-379, 1990

20. Pridie KH: A method of resurfacing osteoarthritic knee joints. J Bone Joint Surg 41B:618-619, 1959

21. Dzioba RB: The classification and treatment of acute articular cartilage lesions. Arthroscopy 4(2):72-80, 1988

22. Blevins FT, Steadman JR, Rodrigo JJ, Silliman J: Treatment of articular cartilage defects in athletes: an analysis of functional outcome and lesion appearance.

Orthopedics 21(7):761-768, 1998

23. Ficat RP, Ficat C, Gédéon P: Spongialization: A new treatment for diseased patellae. Clin Orth 144:74-83, 1979

24. Johnson-Nurse C, Dandy DJ: Fracture-separation of articular cartilage in the adult knee. J Bone Joint Surg 67-B(1):42-43, 1985

25. Czitrom AA, Langer F, McKee N, Gross AE: Bone and cartilage allotransplantation. Clin Orthop 208(Jul):141-145, 1986

26. Tomford WW, Duff GP, Mankin HJ: Experimental freeze-preservation of chondrocytes. Clin Orthop 197:11-14, 1985

27. Czitrom AA, Keating S, Gross AE: The viability of articular cartilage in fresh osteochondral allografts after clinical transplantation. J Bone Joint Surg 72-A(4):574581,1990

28. Mahomed MN, Beaver RJ, Gross AE: The long-term success of fresh, small fragment osteochondral allografts used for intraarticular post-traumatic defects in the knee joint. Orthopedics 15(10):1191-1199, 1992 
29. Matsusue Y, Yamamuro T, Hama H: Arthroscopic multiple osteochondral transplantation to the chondral defect in the knee associated with anterior cruciate ligament disruption. Arthroscopy 9(3):318-321, 1993

30. Hangody L, Kish G, Kárpáti Z, Szerb I, Udvarhelyi I: Arthroscopic autogenous osteochondral mosaicplasty for the treatment of femoral condylar articular defects. Knee Surg Sports Traumatol. Arthrosc. 5:262-267, 1997

31. Hangody L, Kish G, Kárpáti Z, Udvarhelyi I, Szigeti I, Bély M: Mosaicplasty for the treatment of articular cartilage defects: Application in clinical practice. Orthopedics 21(7):751-756, 1998

32. Bentley G, Greer RB: Homotransplantation of isolated epiphyseal and articular cartilage chondrocytes into joint surfaces of rabbits. Nature 230(9):385-388, 1971

33. Itay S, Abramovici A, Nevo Z: Use of cultured embryonal chick epiphyseal chondrocytes as grafts for defects in chick articular cartilage. Clin Orthop 220:284-303, 1987

34. Brittberg M, Lindahl A, Nilsson A, Ohlsson C, Isaksson O, Peterson L: Treatment of deep cartilage defects in the knee with autologous chondrocyte transplantation. $N$ Engl $J$ Med 331(14):889-895, 1994

35. Caplan AI: Mesenchymal stem cells. J Orthop Res 9(5):641-650, 1991

36. Goldberg VM, Stevenson S: Natural history of autografts and allografts. Clin Orthop 225:7-16, 1987

37. Nakahara H, Goldberg VM, Caplan AI: Culture-expanded human periosteal-derived cells exhibit osteochondral potential in vivo. J Orthop Res 9:465-476, 1991

38. Gallay SH, Miura Y, Commisso CN, Fitzsimmons JS, O'Driscoll SW: Relationship of donor site to chondrogenic potential of periosteum in vitro. J Orthop Res 12(4):515525,1994

39. O'Driscoll SW, Salter RB: The induction of neochondrogenesis in free intra-articular periosteal autografts under the influence of continuous passive motion. J Bone Joint Surg 56-A(8):1248-1257, 1984

40. O'Driscoll SW, Keeley FW, Salter RB: The chondrogenic potential of free autogenous periosteal grafts for biological resurfacing of major full-thickness defects in joint surfaces under the influence of continuous passive motion. J Bone Joint Surg 68A(7):1017-1035, 1986

41. O'Driscoll SW, Salter RB: The repair of major osteochondral defects in joint surfaces by neochondrogenesis with autogenous osteoperiosteal grafts stimulated by continuous passive motion. Clin Orthop 208:131-140, 1986

42. Moran ME, Kim HKW, Salter RB: Biological resurfacing of full-thickness defects in patellar articular cartilage of the rabbit. J Bone Joint Surg 74-B(5):659-667, 1992

43. Bruns J, Kersten P, Lierse W, Silbermann M: Die autologe Transplantation von Rippenperichondrium zur Behandlung von tiefen Knorpeldefekten am Kniegelenk des Schafs. Morphologischer Vergleich zweier resorbierbarer Fixationsmethoden. Unfallchirurg 96:462-467, 1993 
44. Bruns J, Kersten P, Lierse W, Silbermann M: Autologous rib perichondrial grafts in experimentally induced osteochondral lesions in the sheep-knee joint: morphological results. Virchows Arch [A] 421(1):1-8, 1992

45. Homminga GN, Bulstra SK, Bouwmeester SJM, van der Linden AJ: Perichondrial grafting for cartilage lesions of the knee. J Bone Joint Surg 72-B:1003-1007, 1990

46. Homminga GN, van der Linden AJ, Terwindt-Rouwenhorst EAW, Drukker J: Repair of articular defects by perichondrial grafts. Experiments in the rabbit. Acta Orthop Scand 60(3):326-329, 1989

47. Bulstra SK, Homminga GN, Buurman WA, Terwindt-Rouwenhorst E, van der Linden AJ: The potential of adult human perichondrium to form hyaline cartilage in vitro. $J$ Orthop Res 8:328-335, 1990

48. Homminga GN, Bulstra SK, Kuijer R, van der Linden AJ: Repair of sheep articular cartilage defects with a rabbit costal perichondrial graft. Acta Orthop Scand 62(5):415418, 1991

49. Radin EL, Paul IL, Rose RM: Role of mechanical factors in pathogenesis of primary osteoarthritis. Lancet 1(Mar):519-521, 1972

50. Von Schroeder HP, Kwan M, Amiel D, Coutts RD: The Use of Polylactic Acid Matrix and Periosteal Grafts for the Reconstruction of Rabbit Knee Articular Defects. J Biomed Mater Res 25(3):329-339, 1991

51. Van Blitterswijk CA, Hesseling SC, van den Brink J, Leenders H, Bakker D: Polymer reactions resulting in bone bonding: A Review of the biocompatibility of Polyactive. In: The Tissue-Material Interface, ed by JE Davies, Toronto, Buffalo, London, University of Toronto Press:295-307, 1991

52. Van Blitterswijk CA, Grote JJ, Hesseling SC, Bakker D: Polyactive: A bone-bonding polymer. In: Interfaces in Medicine and Mechanics-2, ed by KR Williams, A Toni, J Middleton, G Pallotti, London, Elsevier Science Publishers LTD:1-9, 1991

53. Hanff G, Danielsen N, Thomsen P: E-PTFE in rabbit knee-joints. J Mater Sci Mater Med 5:473-480, 1994

54. Robinson PD: Articular cartilage of the temporomandibular joint: Can it regenerate? Annals of the Royal College of Surgeons of England 75(4):231-236, 1993

55. Reissis N, Downes S, Kayser M, Bentley G: A simple method of cartilage regeneration using a new polymerizing system: ultrastructural characteristics of the repair tissue. $J$ Mater Sci Mater Med 5:793-797, 1994

56. Lester CW: Tissue replacement after perichondrial arthroplasty. Plast Reconstr Surg 23:49, 1959

57. Shands AR: The regeneration of hyaline cartilage in joints. An experimental study. Arch Surg 22:137-178, 1930

58. Skoog T, Ohlsén L, Sohn SA: Perichondrial potential for cartilagenous regeneration. Scand J Plast Reconstr Surg 6:123-125, 1972

59. Skoog T, Ohlsén L, Sohn SA: The chondrogenic potential of the perichondrium. Chir Plastica 3:91-103, 1975 
60. Ohlsén L: Cartilage regeneration from perichondrium. Plast Reconstr Surg 62(4):507513,1978

61. Wasteson $\AA$, Ohlsén L: Biosynthesis of chondroitin sulphate in cartilage regenerated from perichondrium. Scand J Plast Reconstr Surg 11:17-22, 1977

62. Tajima S, Aoyagi F, Maruyama Y: Free perichondrial grafting in the treatment of temporomandibular joint ankylosis. Plast Reconstr Surg 61:876-880, 1978

63. Engkvist $\mathrm{O}$, Ohlsén L: Reconstruction of articular cartilage with free autologous perichondrial grafts. Scand J Plast Reconstr Surg 13:269-274, 1979

64. Engkvist O, Skoog V, Pastacaldi P, Yormuk E, Juhlin R: The cartilagenous potential of the perichondrium in rabbit ear and rib. Scand J Plast Reconstr Surg 13:275-280, 1979

65. Maruyama Y: An experimental study on cartilage formation in autogenous perichondrial transplantation in rabbits. Keio J Med 28:63-72, 1979

66. Upton J, Sohn SA, Glowacki J: Neocartilage derived from transplanted perichondrium: What is it? Plast Reconstr Surg 68(2):166-174, 1981

67. Engkvist O, Johansson SH: Perichondrial Arthroplasty. Scand J Plast Reconstr Surg $14: 71-87,1980$

68. Sully L, Jackson IT, Sommerlad BC: Perichondrial grafting in rheumatoid metacarpophalangeal joints. Hand 12:137-148, 1980

69. Kon M: Cartilage formation from perichondrium in a weight-bearing joint. Eur Surg Res 13:387-396, 1981

70. Ohlsén L, Widenfalk B: The early development of articular cartilage after perichondrial grafting. Scand J Plast Reconstr Surg 17:163-177, 1983

71. Coutts RD, Amiel D, Woo SL-Y, Woo Y-K, Akeson WH: Technical aspects of perichondrial grafting in the rabbit. Eur Surg Res 16:322-328, 1984

72. Seradge H, Kutz JA, Kleinert HE, Lister GD, Wolff TW, Atasoy E: Perichondrial resurfacing arthroplasty in the hand. Hand 9-A(6):880-886, 1984

73. Widenfalk B, Engkvist O, Ohlsén L, Segerström K: Perichondrial arthroplasty using fibrin glue and early mobilization. An experimental study. Scand J Plast Reconstr Surg 20(3):251-258, 1986

74. Woo SL-Y, Kwan MK, Lee TQ, Field FP, Kleiner JB, Coutts RD: Perichondrial autograft for articular cartilage. Shear modulus of neocartilage studied in rabbits. Acta Orthop Scand 58:510-515, 1987

75. Amiel D, Coutts RD, Harwood FL, Ishizue KK, Kleiner JB: The chondrogenesis of rib perichondrial grafts for repair of full thickness articular cartilage defects in a rabbit model:a one year post-operative assessment. Connect Tissue Res 18:27-39, 1988

76. Ranawat CS, Insall J, Shine J: Duo-condylar knee arthroplasty: hospital for special surgery design. Clin Orthop 120:76-82, 1976

77. Gillquist J, Hagberg G, Oretorp N: Arthroscopy in acute injuries of the knee joint. Acta Orthop Scand 48:190-196, 1977

78. Dandy DJ: Arthroscopic surgery of the knee. Edinburgh, Churchill Livingstone, 1981 
79. Bauer M, Jackson RW: Chondral lesions of the femoral condyles: a system of arthroscopic classification. Arthroscopy 4(2):97-102, 1988

80. Furukuwa T, Eyre DR, Koide S, Glimcher MJ: Biochemical studies on repair cartilage resurfacing experimental defects in the rabbit knee. J Bone Joint Surg Am 62:79-89, 1980

81. Skoog $\mathrm{T}$, Johansson SH: The formation of articular cartilage from free perichondrial grafts. Plast Reconstr Surg 61:876-880, 1978

82. O'Driscoll SW, Keeley FW, Salter RB: Durability of regenerated articular cartilage produced by free autogenous periosteal grafts in major full-thickness defects in joint surfaces under the influence of continuous passive motion. A follow-up report at one year. J Bone Joint Surg 70-A(4):595-606, 1988

83. Hvid I, Andersen LI: Perichondrial autograft in traumatic chondromalacia patellae. Report of a case. Acta Orthop Scand 52:91-93, 1981

84. Jackson IT, Sully L, Tanner NSB, McGlynn MJ: An interpositional elastomeric cap for metacarpophalangeal joint perichondrioplasty in rheumatoid arthritis. Hand 13(2):158163,1981

85. Ascherl R, Scherer M, Stemberger A, Weichenmeier I, Blümel G: Zusätzliche Nahtsicherung am Kolon mit verschiedenen Techniken der FibrinklebungExperimentelle Untersuchungen an der Ratte. Stuttgart, Springer-Verlag:120-127, 1984

86. Schlag G, Redl H: Fibrin sealant in orthopaedic surgery. Clin Orthop 227:269-285, 1988

87. Claes L, Burri C, Helbing G, Lehner E: Biomechanische Untersuchungen zur Festigkeit verschiedener Knorpelklebungen. Helv Chir Acta 48:11-13, 1981

88. Braun A, Schumacher G, Heine WD: Fibrin-Klebung osteochondraler Fragmente im Tierexperiment. In: Fibrinkleber in Orthopädie und Traumatologie, ed by $\mathrm{H}$ Cotta, A Braun, Stuttgart, Georg Thieme Verlag:110-124, 1984

89. Salter RB, Simmonds DF, Malcolm BW, Rumble EJ, MacMichael D, Clements ND: The biological effect of continuous passive motion on the healing of full thickness defects in articular cartilage. An experimental investigation of rabbits. $J$ Bone Joint Surg 62-A(8):1232-1251, 1980

90. Plenk jr H, Passl R: Trans- and replantation of articular cartilage using the fibrinogen adhesive system. In: Biology of the articular cartilage in health and disease, ed by $\mathrm{H}$ Gastpar, Munich, Stuttgart and Schlattauer:439-447, 1980

91. Haynes DW: The mineralization front of articular cartilage. Metab Bone Dis \& Rel Res 2S:55-59, 1980

92. Solursh M: Formation of cartilage tissue in vitro. J Cell Biochem 45(3):258-260, 1991

93. Billings E Jr, von Schroeder HP, Mai MT, Aratow M, Amiel D, Woo SL-Y, Coutts RD: Cartilage resurfacing of the rabbit knee. The use of an allogeneic demineralized bone matrix-autogeneic perichondrium composite implant. Acta Orthop Scand 61(3):201206,1990 
94. Coutts RD, Woo SL-Y, Amiel D, von Schroeder HP, Kwan MK: Rib periochondrial autografts in full-thickness articular cartilage defects in rabbits. Clin Orthop 275:263273, 1992

95. Engkvist O, Wilander E: Formation of cartilage from rib perichondrium grafted to an articular defect in the femur condyle of the rabbit. Scand J Plast Reconstr Surg 13:371376, 1979

96. Engkvist O: Reconstruction of patellar articular cartilage with free autologous perichondrial grafts. Scand J Plast Reconstr Surg 13:361-369, 1979

97. Aaron JE: Alkaline phosphatase, vesicles and calcification. Metab Bone Dis \& Rel Res 2S:151-157, 1980

98. Widenfalk B, af Ekenstam F: Perichondrial grafting for total replacement of the patella. Scandinavian Journal of Plastic Reconstructive Hand Surgery 24:97-99, 1990

99. Amiel D, Coutts RD, Abel M, Stewart W, Harwood F, Akeson WH: Rib perichondrial grafts for the repair of full-thickness articular cartilage defects. J Bone Joint Surg 67A(6):911-920, 1985

100. Dandy DJ, Jackson RW: Meniscectomy and chondromalacia of the femoral condyle. $J$ Bone Joint Surg 57-B(8):1116-1119, 1975

101. Gibble JW, Ness PM: Fibrin glue: The perfect operative sealant. Transfusion 30(8):741747, 1990

102. Passl R, Plenk H Jr: Die Fibrinklebung von Knorperlflächen. Beitrage Orthopaedie und Traumatologie 36(10-11):503-507, 1989

103. Rosson J, Murphy W, Tonge C, Shearer J: Healing of residual screw holes after plate removal. Injury 22(5):383-384, 1991

104. Hidaka S, Gustilo RB: Refracture of bones of the forearm after plate removal. J Bone Joint Surg Am 66-A(8):1241-1243, 1984

105. Böstman OM: Refracture after removal of a condylar plate from the distal third of the femur. J Bone Joint Surg Am 72-A(7):1013-1018, 1990

106. Mih AD, Cooney WP, Idler RS, Lewallen DG: Long-term follow-up of forearm bone diaphyseal plating. Clin Orthop 299:256-258, 1994

107. Rosson JW, Shearer JR: Refracture after the removal of plates from the forearm. An avoidable complication. J Bone Joint Surg 73-B(3):415-417, 1991

108. Bakker D, Grote JJ, Vrouenraets CMF, Hesseling SC, de Wijn JR, van Blitterswijk CA: Bone-bonding polymer (Polyactive). In: Clinical Implant Materials, ed by G Heimke, U Soltesz, AJC Lee, London, Elsevier Science Publishers LTD:99-104, 1990

109. Bakker D, Heinze RP, Goedemoed JH, van Blitterswijk CA (1993): Poly(ethylene glycol) - poly(butylene terephthalate) block copolymers: Future possibilities for the system of Polyactive biomaterials. Sen-i-Gakkai Symposium Preprints; A33-A36

110. Van Blitterswijk CA, van der Brink J, Leenders H, Bakker D: The effect of PEO ratio on degradation, calcification and bone bonding of PEO/PBT copolymer (Polyactive). Cells Mater 3(1):23-36, 1993 
111. Beumer GJ, van Blitterswijk CA, Ponec M: Biocompatibility of a biodegradable matrix used as a skin substitute: an in vivo evaluation. J Biomed Mater Res 28(5):545-552, 1994

112. Beumer GJ, van Blitterswijk CA, Ponec M: Degradative behaviour of polymeric matrices in (sub)dermal and muscle tissue of the rat: a quantitative study. Biomaterials 15(7):551-559, 1994

113. Radder AM, Davies JE, Leenders H, van Blitterswijk CA: Interfacial behavior of PEO/PBT copolymers (Polyactive) in a calvarial system: An in vitro study. J Biomed Mater Res 28(2):269-277, 1994

114. Harada K, Oida S, Sasaki S: Chondrogenesis and osteogenesis of bone marrow-derived cells by bone-inductive factor. Bone 9:177-183, 1988

115. Grundel RE, Chapman MW, Yee T, Moore DC: Autogeneic bone marrow and porous biphasic calcium phosphate ceramic for segmental bone defects in the canine ulna. Clin Orthop 266:244-258, 1991

116. Okumura M, van Blitterswijk CA, Koerten HK, Bakker D, Hesseling SC, de Groot K: Bone formation process in porous PEO/PBT copolymer (Polyactive): A histological study of ectopic bone formation induced by rat bone marrow cells. In: Bone-bonding Biomaterials, ed by P Ducheyne, T Kokubo, CA van Blitterswijk, Leiderdorp, The Netherlands, Reed Healthcare Communications:189-199, 1992

117. Van Blitterswijk CA, Grote JJ, Kuijpers W, Daems WT, de Groot K: Macropore tissue ingrowth: A quantitative and qualitative study on hydroxyapatite ceramic. Biomaterials 7:137-143, 1986

118. Predecki P, Stephan JE, Auslaender BA, Mooney VL, Kirkland K: Kinetics of bone growth into cylindrical channels in aluminium oxide and titanium. J Biomed Mater Res 6:375-400, 1972

119. Sauren YMHF: Ultrastructural Histochemistry of Proteoglycans in the Organic Matrix of Bone and Cartilage. Ph.D. thesis, Leiden, 1991

120. Van Blitterswijk CA, Bakker D, Leenders H, van den Brink J, Hesseling SC, Bovell YP, Radder AM, Sakkers RJ, Gaillard ML, Heinze PH, Beumer GJ: Interfacial reactions leading to bone-bonding with PEO/PBT copolymers (Polyactive). In: Bone-bonding Biomaterials, ed by P Ducheyne, T Kokubo, CA van Blitterswijk, Leiderdorp, The Netherlands, Reed Healthcare Communications:13-30, 1992

121. Huiskes R, Weinans H, Grootenboer HJ, Dalstra M, Fudala B, Slooff TJ: Adaptive bone-remodelling theory applied to prosthetic-design analysis. J Biomech 20(11):11351150,1987

122. Huiskes R, Nunamaker D: Local stresses and bone adaption around orthopaedic implants. Calcif Tissue Int 36:110-117, 1984

123. Frost HM: A determinant of bone architecture, the minimum effective strain. Clin Orthop 175:286-292, 1983

124. Rubin CT, Lanyon LE: Regulation of bone formation by applied dynamic loads. $J$ Bone Joint Surg 66-A(3):397-402, 1984 
125. Wolff J: Das Gesetz der Transformation der Knochen. Ph.D. thesis, Berlin, Hirschwald, 1892

126. Gaillard ML, van den Brink J, van Blitterswijk CA, Luklinska ZB: Applying a calcium phosphate layer on PEO/PBT copolymers affects bone formation in vivo. JMater Sci Mater Med 5:424-428, 1994

127. Friedlaender GE: Bone banking. In support of reconstructive surgery of the hip. Clin Orthop 225:17-21, 1987

128. Martin RB, Chapman MW, Sharkey NA, Zissimos SL, Bay B, Shors EC: Bone ingrowth and mechanical properties of coralline hydroxyapatite $1 \mathrm{yr}$ after implantation. Biomaterials 14(5):341-348, 1993

129. Bucholz RW, Carlton A, Holmes RE: Hydroxyapatite and tricalcium phosphate bone graft substitutes. Orthop Clin North Am 18(2):323-334, 1987

130. Geesink RGT: Hydroxyl-apatite coated hip implants: Experimental and clinical studies. In: Bone-bonding Biomaterials, ed by P Ducheyne, T Kokubo, CA van Blitterswijk, Leiderdorp, The Netherlands, Reed Healthcare Communications:121-137, 1992

131. Holmes RE, Bucholz RW, Mooney V: Porous hydroxyapatite as a bone graft substitute in diaphyseal defects: A histometric study. J Orthop Res 5:114-121, 1987

132. Müller-Mai C, Voigt C, Knarse W, Sela J, Gross UM: The early host and material response of bone-bonding and non-bonding glass-ceramic implants as revealed by scanning electron microscopy and histochemistry. Biomaterials 12:865-871, 1991

133. Van Blitterswijk CA, Grote JJ, Kuijpers W, Blok-van Hoek CJG, Daems WT: . Biomaterials 6:243-251, 1985

134. Mullender MG, Huiskes R: Proposal for the regulatory mechanism of Wolff's law. $J$ Orthop Res 13(4):503-512, 1995

135. Radder AM: Bone-bonding copolymers for hard tissue replacement. Ph.D. thesis, Leiden, 1994

136. Dupoirieux L, Costes V, Jammet P, Souyris F: Experimental study on demineralized bone matrix (DBM) and coral as bone graft substitutes in maxillofacial surgery. Int $J$ Oral Maxillofac Surg 23:395-398, 1994

137. Zdeblick TA, Cooke ME, Kunz DN, Wilson D, McCabe RP: Anterior discectomy and fusion using a porous hydroxyapatite bone graft substitute. Spine 19(20):2348-2357, 1994

138. Yamamuro T, Shimizu K: Clinical application of AW glass ceramic prosthesis in spinal surgery. Nippon Seikeigeka Gakkai Zasshi 68(7):505-515, 1994

139. Campbell CJ: The healing of cartilage defects. Clin Orthop 64(May-June):45-63, 1969

140. DePalma AF, McKeever CD, Sabin DK: Process of repair of articular cartilage by histology and autoradiography with tritiated thymidine. Clin Orthop 48:229-242, 1966

141. Tanaka H, Shinno N: Histochemical studies on regeneration of articular cartilage. J Exp Med 18:63-73, 1971

142. Furukawa T, Eyre DR, Koide S, Glimcher MJ: Biochemical studies on repair cartilage resurfacing experimental defects in the rabbit knee. J Bone Joint Surg 62-A:79-89, 1980 
143. Engkvist O, Johansson SH, Ohlsén L, Skoog T: Reconstruction of articular cartilage using autologous perichondrial grafts. A preliminary report. Scand J Plast Reconstr Surg 9:203-206, 1975

144. Zarnett R, Delaney JP, O'Driscoll SW, Salter RB: Cellular origin and evolution of neochondrogenesis in major full thickness defects of a joint surface treated by free autogenous periosteal grafts and subjected to continuous passive motion in rabbits. Clin Orthop 222:267-274, 1987

145. Widenfalk B, Engkvist O, Segerström K: Perichondrial arthroplasty using fibrin glue and early mobilization. Scand J Plast Reconstr Surg 20:251-258, 1986

146. Von der Mark K, Kirsch T, Nerlich A, Kuss A, Weseloh G, Glückert K, Stöss H: Type $\mathrm{X}$ collagen synthesis in human osteoarthritic cartilage. Indication of chondrocyte hypertrophy. Arthritis Rheum 35(7):806-811, 1992

147. O'Driscoll SW, Salter RB, Keeley FW: A method for quantitative analysis of ratios of Types I and II collagen in small samples of articular cartilage. Anal Biochem 145:277285,1985

148. Kuijer R, van de Stadt RJ, de Koning MHMT, van der Korst JK: Influence of constituents of proteoglycans on Type II collagen fibrillogenesis. Collagen Rel Res 5:379-391, 1985

149. Van der Sluijs JA, Geesink RGT, van der Linden AJ, Bulstra SK, Kuijer R, Drukker J: The reliability of the mankin score for osteoarthritis. J Orthop Res 10:58-61, 1992

150. Dean DD, Martel-Pelletier J, Pelletier J-P, Howell DS, Woessner JF Jr: Evidence for metalloproteinase and metalloproteinase inhibitor imbalance in human osteoarthritic cartilage. J Clin Invest 84:678-685, 1989

151. Kirsch T, von der Mark K: Isolation of human Type X collagen and immunolocalization in fetal human cartilage. Eur J Biochem 196(3):575-580, 1991

152. Woessner JF: Matrix metalloproteinases and their inhibitors in connective tissue remodeling. FASEB J 5(8):2145-2154, 1991

153. Bouwmeester SJM, Beckers JMH, Kuijer R, van der Linden AJ, Bulstra SK: Long-term results of rib perichondrial grafts for the repair of cartilage defects in the human knee. Int Orthop 21:313-317, 1997

154. Buckwalter JA, Mow VC, Ratcliffe A: Restoration injured or degenerated articular cartilage. Journal of the American Academy of Orthopaedic Surgeons 2:192-201, 1994

155. Kwan MK, Coutts RD, Woo SL-Y, Field FP: Morphological and biomechanical evaluations of neocartilage from the repair of full-thickness articular cartilage defects using rib perichondrium autografts: A long-term study. J Biomech 22(8-9):921-930, 1989

156. Nehrer S, Young G, Spector M, Minas T (1997): Mechanisms of failure of cartilage repair procedures in humans. Histological analysis of retrieved tissue. 43rd Annual Meeting, Orthopaedic Research Society, February 9-13, San Francisco, California

157. Outerbridge RE: The etiology of chondromalacia patellae. J Bone Joint Surg Br 19B:752, 1989 
158. Rubak JM: Reconstruction of articular cartilage defects with free periosteal grafts. Acta Orthop Scand 53:175-180, 1982

159. Minas T, Nehrer S: Current concepts in the treatment of articular cartilage defects. Orthopedics 20(6):525-538, 1997

160. Newman AP: Articular cartilage repair. Am J Sports Med 26(2):309-324, 1998

161. Bobić V: Arthroscopic osteochondral autograft transplantation in anterior cruciate ligament reconstruction: A preliminary clinical study. Knee Surg Sports Traumatol. Arthrosc. 3:262-264, 1996

162. Dieppe P: Osteoarthritis and molecular markers. A rheumatologist's perspective. Acta Orthop Scand Suppl 66:1-5, 1995

163. Thal R, Danziger MB, Kelly A: Delayed articular cartilage slough: Two cases resulting from Holmium:YAG laser damage to normal articular cartilage and a review of the literature. Arthroscopy 12:92-94, 1996

164. Nakajima H, Goto T, Horikawa O, Kikuchi T, Shinmei M: Characterization of the cells in the repair tissue of full-thickness articular cartilage defects. Histochemistry Cell Biol 109:331-338, 1998

165. Menche DS, Frenkel SR, Blair B, Watnik NF, Toolan BC, Yaghoubian RS, Pitman MI: A comparison of abrasion burr arthroplasty and subchondral drilling in the treatment of full-thickness cartilage lesions in the rabbit. Arthroscopy 12(3):280-286, 1996

166. Bouwmeester SJM, Kuijer R, Sollie-Drees MMWE, van der Linden AJ, Bulstra SK: Long-term results of rib perichondrial grafts for repair of cartilage defects in the human knee. Int Orthop 21:313-317, 1997

167. Király K, Hyttinen MM, Lapveteläinen T, Elo M, Kiviranta I, Dobai J, Módis L, Helminen HJ, Arokoski JPA: Specimen preparation and quantification of collagen birefringence in unstained sections of articular cartilage using image analysis and polarizing light microscopy. Histochem J 29:317-327, 1997

168. Jurgensen K, Aeschlimann D, Cavin V, Genge M, Hunziker EB: A new biological glue for cartilage-cartilage interfaces: tissue transglutaminase. J Bone Joint Surg Am 79A(2):185-193, 1997

169. Orr TE, Patel AM, Wong B, Hatzigiannis GP, Minas T, Spector M: Attachment of periosteal grafts to articular cartilage with fibrin sealant. J Biomed Mater Res 44(3):308313, 1999

170. Breinan HA, Minas T, Hsu HP, Nehrer S, Sledge CB, Spector M: Effect of cultured autologous chondrocytes on repair of chondral defects in a canine model. $J$ Bone Joint Surg Am 79-A(10):1439-1451, 1997

171. Nethery A, Giles I, Jenkins K, Jackson C, Brooks P, Burkhardt D, Ghosh P, Whitelock J, O'Grady RL, Welgus HG, Schrieber L: The chondroprotective drugs, arteparon and sodium pentosan polysulphate, increase collagenase activity and inhibit stromelysin activity in vitro. Biochem Pharmacol 44(8):1549-1553, 1992 
172. Moskowitz RW, Reese JH, Young RG, Fein-Krantz D, Malemud CJ, Caplan AI: The effects of rumalon, a glycosaminoglycan peptide complex, in a partial meniscectomy model of osteoarthritis in rabbits. J Rheumat 18(2):205-209, 1991

173. Brittberg M, Faxén E, Peterson L: Carbon fiber scaffolds in the treatment of early knee osteoarthritis. Clin Orthop 307:155-164, 1994

174. Dounchis JS, Goomer RS, Harwood FL, Khatod M, Coutts RD, Amiel D:

Chondrogenic phenotype of perichondrium-derived chondroprogenitor cells is influenced by transforming growth factor-beta 1.J Orthop Res 15:803-807, 1997

175. Klein-Nulend J, Louwerse RT, Heyligers IC, Wuisman PIJM, Semeins CM, Goei SW, Burger EH: Osteogenic protein (OP-1, BMP-7) stimulates cartilage differentiation of human and goat perichondrium tissue in vitro. J Biomed Mater Res 40(4):614-620, 1998

176. Lane Smith R, Palathumpat MV, Ku CW, Hintz RL: Growth hormone stimulates insulin-like growth factor 1 actions on adult articular chondrocytes. J Orthop Res 7:198207, 1989

177. Wakitani S, Goto T, Pineda SJ, Young RG, Mansour JM, Caplan AI, Goldberg VM: Mesenchymal cell-based repair of large, full-thickness defects of articular cartilage. $J$ Bone Joint Surg Am 76-A(4):579-592, 1994

178. Bulstra SK, Douw C, Kuijer R: Hyaluronic acid restores cartilage metabolism of the rat in vivo, that was inhibited by irrigation with Nacl. Trans Eur Orthop Res Soc 8:21, 1998 


\section{Dankwoord}

De afronding van een studie als deze dwingt je bijna vanzelfsprekend na te gaan waar het allemaal mee begonnen is. De gedachten komen dan niet zozeer uit bij de feiten die in het curriculum vitae te vinden zijn maar veel meer bij de mensen die op beslissende momenten voor je klaar gestaan hebben, je gestimuleerd hebben of waar je je verhaal kwijt kon. Allereerst denk ik dan aan mijn ouders die met zo veel belangstelling en warmte studie en alles daaromheen mogelijk gemaakt hebben.

Beslissend voor het ontstaan van dit proefschrift in wetenschappelijk opzicht is Prof. Dr A.J. van der Linden geweest. Hij wist mij op bijna vanzelfsprekende wijze in 1990 bij het onderwerp te betrekken. Voordat ik het me goed realiseerde was ik aan een promotie begonnen. Ik ben hem dankbaar dat hij mij indertijd tot dit avontuur heeft verleid.

Mijn promotor, Prof. Dr R.G.T. Geesink, dank ik voor zijn grote rol in de laatste fase van het onderzoek. Ruud, ik bewonder je kennis en kunde op orthopaedisch en wetenschappelijk gebied bijzonder. Je hulp de afgelopen tijd, naast al je andere drukke werkzaamheden, was meer dan bijzonder. Je commentaar werd voorzichtig en gedoseerd gebracht maar was daarmee tegelijkertijd zeer terecht en tijdig. Je bereidheid mee te gaan in mijn onstuimige werkwijze was meer dan normaalgesproken gevraagd kan worden.

Mijn co-promotores, Dr S.K. Bulstra en Dr R. Kuijer, vervulden ieder zo hun eigen rol. Sjoerd, bedankt voor al het geregel achter de coulissen. Gelukkig kon ik je vaak in de wandelgang aan de riem van je witte jas trekken om je op de plaats rust te dwingen. Dat waren de momenten waarop je half onleesbare correcties ontcijferd konden worden.

Roel, laten we eerlijk zijn: als jij niet met grote regelmaat had geduwd en getrokken was er van het proefschrift niets terecht gekomen. Eigenlijk ligt het boekje er dankzij jou. Wat ik altijd zo bijzonder gewaardeerd heb is je aandacht voor het persoonlijke naast het zakelijke. Nooit deed ik tevergeefs een beroep op je, ook niet als ik bezig was met een tussensprint. Je wist het schip dan telkens vlot te trekken, zowel in intellectueel als in praktisch opzicht. 
De leden van de beoordelingscommissie dank ik voor de tijd die zij aan dit proefschrift hebben willen geven en de daarbij getoonde belangstelling.

De vakgroep pathologie heeft door haar gastvrijheid een thuisbasis geleverd voor het laboratoriumwerk. Daarbij werd dankbaar gebruik gemaakt van de aanwezige kennis. Els Terwindt-Rouwenhorst sneed met groot geduld de histologie blokjes waarin door mijn ongeduld tijdens het verwerkingsproces toch nog teveel kalk zat. De vakkundige aanpak van het laboratorium anatomie zorgde uiteindelijk voor het juiste resultaat. Ton van de Bogaard en Peter Kelderman van de proefdierenvoorziening dank ik hartelijk voor hun hulp bij de konijnenexperimenten.

Rieny van den Munckhof en Nicolette Hoefnagels wil ik hartelijk danken voor het feit dat in mijn ogen bijna onmogelijk uit te voeren statistische opdrachten per omgaande verwerkt konden worden. Don Surtel voerde gecompliceerde biochemische analyses uit; ik ben er nog niet zeker van of ik ze inmiddels allemaal begrijp.

De AV dienst van het ziekenhuis heeft enorm bijgedragen door de perfecte foto's en ander materiaal dat zij in het kader van dit proefschrift hebben gemaakt. Hun snelle en adequate acties kwamen vooral in de laatste fase zeer van pas.

Marjonne, zus en paranimf, bedankt voor de hulp bij het verbeteren van de grootste engelse blunders.

Mirjam, beste vriendin en paranimf, dank voor je "ontspan", het gelach en het geregel!

Lieve Henk Peter, jij hebt ervoor gezorgd dat de laatste loodjes veel minder zwaar waren. Door je hulp op alle fronten kon dit proefschrift op een goede en snelle manier afgerond worden; ik moet toegeven dat ik het zelfs leuk begon te vinden. Ik ben blij dat je in mijn leven gekomen bent; je bent het beste dat me ooit overkomen is. Ik verheug me op de toekomst.

Veel mensen, zo blijkt al uit het voorgaande, zijn betrokken geweest bij dit proefschrift. Als er mensen zijn die niet genoemd worden, maar wel vinden dat ze bedankt hadden moeten worden dan betreur ik dat (maar toch bedankt natuurlijk!).

Het proefschrift is nu afgerond. Ik zie uit naar de openbare verdediging, maar misschien nog wel meer naar het leven na dit wetenschappelijke hoogtepunt.

Phianne Bouwmeester 


\section{CURRICULUM VITAE}

Phianne Bouwmeester werd op 27 januari 1965 geboren in Maastricht. Na het VWO aan het Eijckhagencollege te Schaesberg werd in 1983 begonnen met de studie geneeskunde aan de toenmalige Rijksuniversiteit Limburg (nu: Universiteit Maastricht).

Tijdens haar studie was zij 3 jaar lang student-assistent bij het Instituut voor Geneesmiddelen, Veiligheid en Gedrag. Vanaf 1987 participeerde ze als studentassistent orthopaedie in wetenschappelijk onderzoek. Dit was de eerste kennismaking met de perichondrium transplantaties. Het artsdiploma werd behaald in 1990 .

Vanaf september 1990 werd als arts-assistent orthopaedie wetenschappelijk onderzoek verricht. Toen werd de basis gelegd van dit proefschrift.

De vooropleiding algemene heelkunde werd vanaf 1 februari 1992 gevolgd in het Academisch Ziekenhuis Maastricht (opleider: Prof. dr G. Kootstra).

De opleiding orthopaedie werd gestart onder leiding van Prof. dr A.J. van der Linden en op 1 maart 1998 afgerond bij Prof. dr R.G.T. Geesink.

Vanaf 1 juli 1998 is zij werkzaam als orthopaedisch chirurg in de Sint Maartenskliniek te Nijmegen.

Op 11 september 1999 treedt zij in het huwelijk met Henk Peter Kip. Ze leefden daarna nog lang en gelukkig. 

$0 \times 1$

$+8$

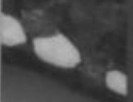

.

1.

)

$(x)=$

20. 